
The Bancroft Library

University of California - Berkeley 

Digitized by the Internet Archive in 2007 with funding from Microsoft Corporation 
DEPAFTMENT OF THV INTERIOR

DNITED STATES GEOROGICAI, SURYEY

GEORGE OTIS SJITH, DIRECTU:

\section{BULLETIN 583}

\section{COLORADO FERBERITE AND THE}

\section{WOLFRAMITE SERIES}

\section{BY}

FRANK L. HESS

AND

WATDEMAR T. SCHATLER

WAS II INGTON

GOYERNMENT PRINTING OFFICE 


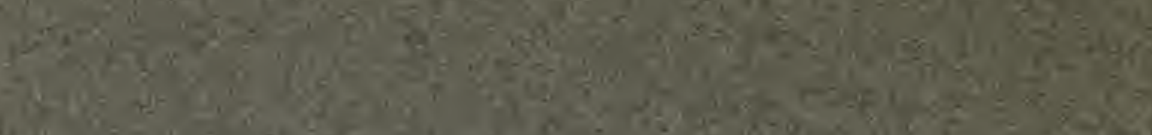

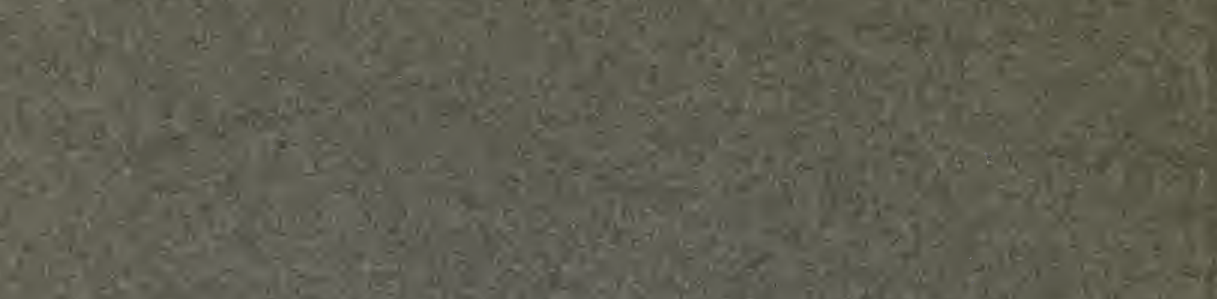

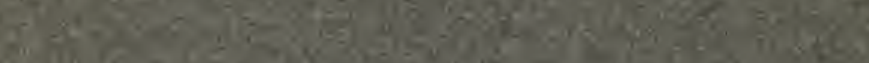

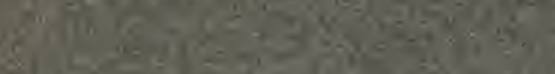

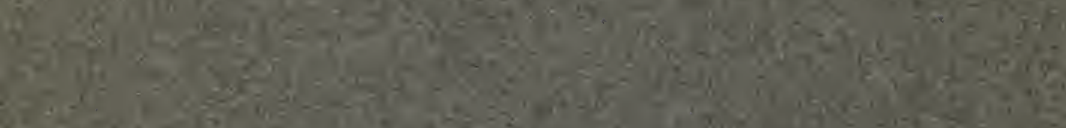

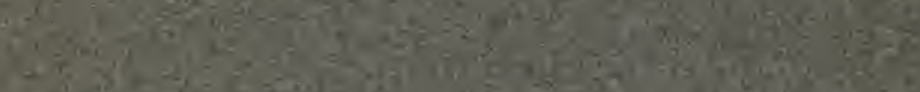

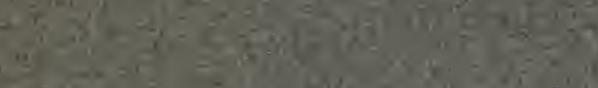
$\lim ^{-15}$
$x_{3} \log ^{\circ}, 3^{\circ}$

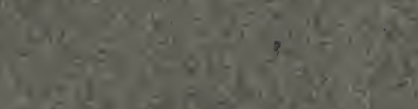
$x^{2}+2 x+y=5$

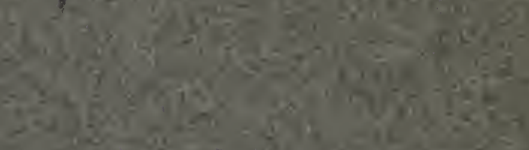

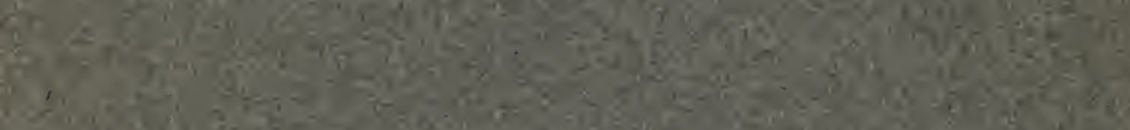

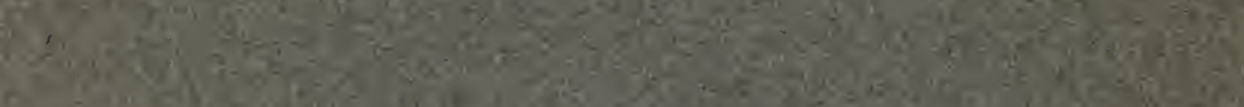

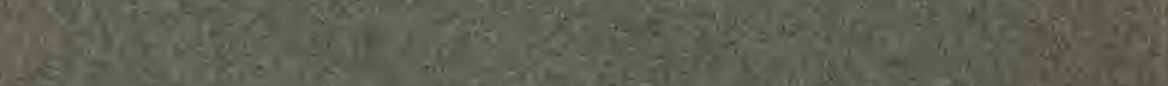

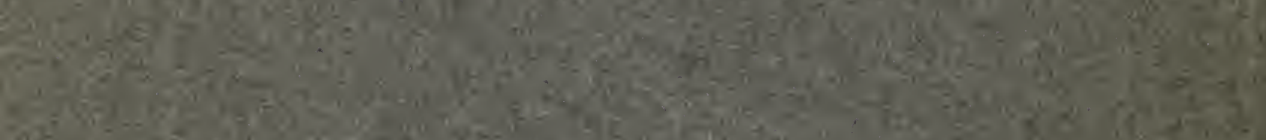

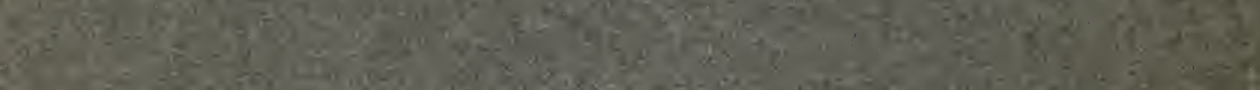

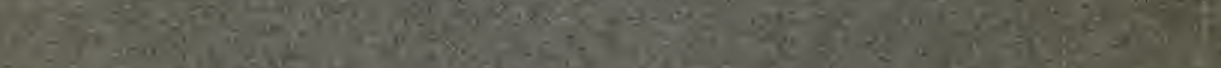

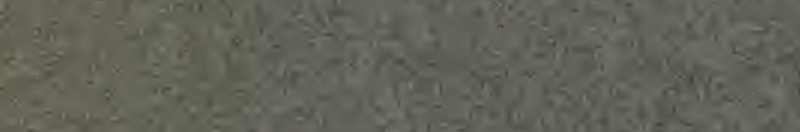

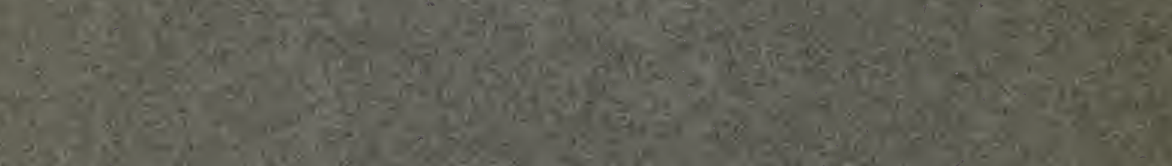
2.

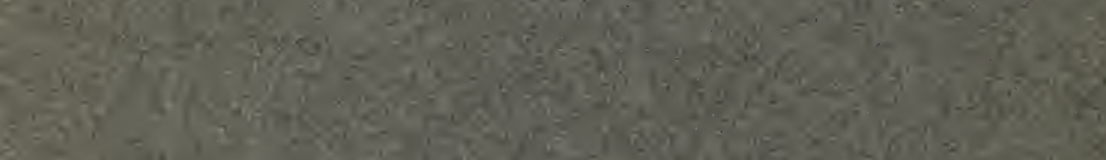

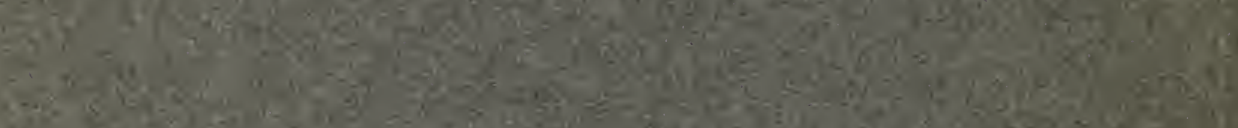

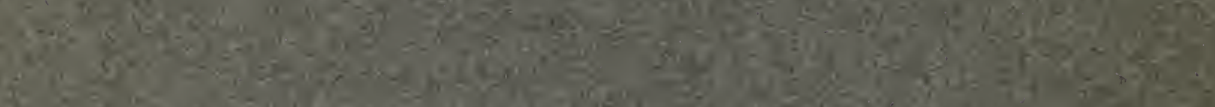

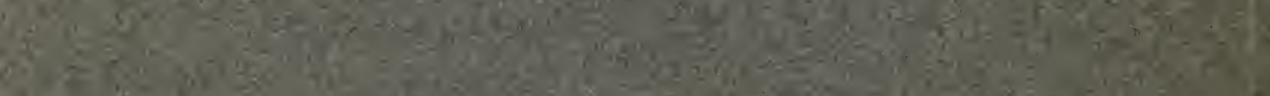

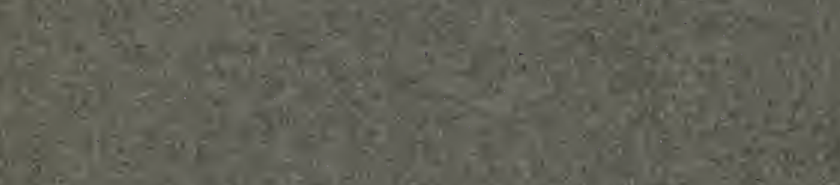

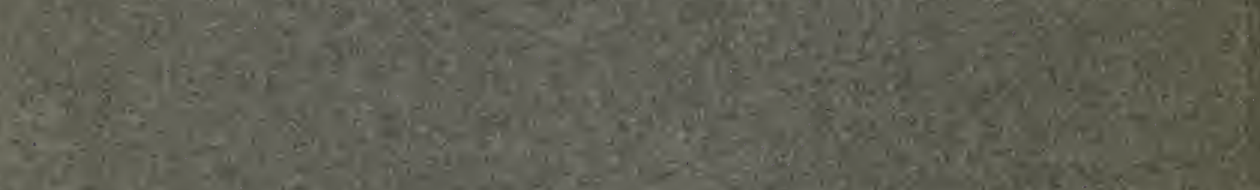

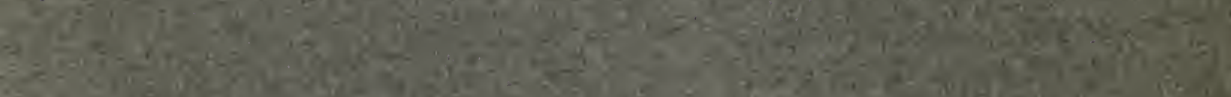

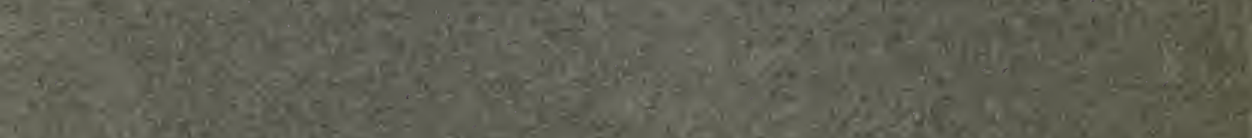

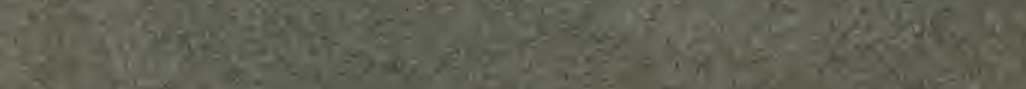

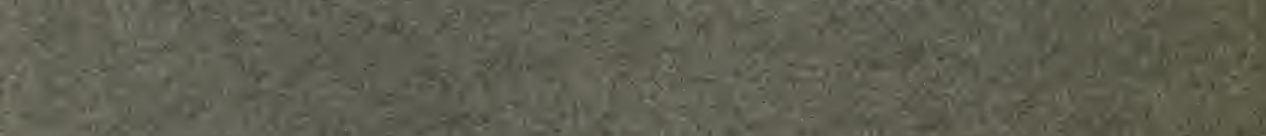

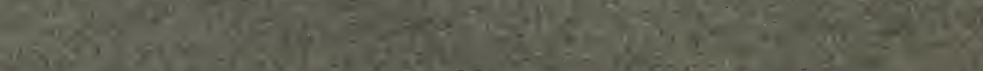


DEPARTMENT OF THE INTERIOR

UNITED STATES GEOLOGICAL SURVEY

GEORGE OTIS SMITH, DIRECTOR

BuLLetiN 583

\title{
COLORADO FERBERITE AND THE WOLFRAMITE SERIES
}

\author{
BY \\ FRANK L. HESS \\ AND \\ WALDEMAR T. SCHALLER
}

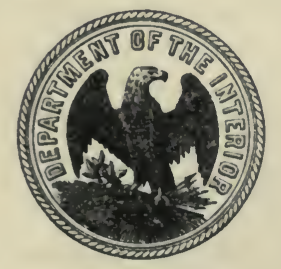

WASHINGTON

GOVERNMENT PRINTING OFFICE

1914 



\section{CONTENTS.}

The Mineral Retations of Ferberite, by Frank

Geography and production................................. 7

Characteristics of the ferberite................................. ${ }_{8}$

Geography and geology of the Boulder district..................... 8

Occurrence, vein systems, and relations......................... 9

Characteristics of the ore . .................................... 10

Minerals associated with the ferberite............................ 12

Adularia............................................ 12

Calcite............................................ 12

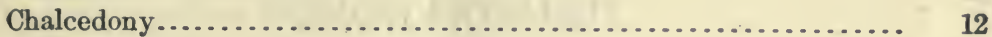

Chalcopyrite......................................... 12

Galena............................................. ${ }_{12}$

Gold and silver...................................... 12

Hamlinite (?) . . . . . . . . . . . . . . . . . . . . . . . . . . . . .

Hematite (specular) ..................................... 15

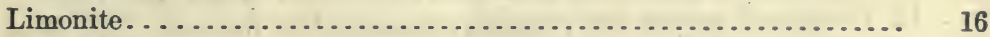

Magnetite........................................... $\quad 17$

Molybdenite....................................... $\quad 17$

Opal............................................... 17

Pyrite................................................ 17

Quartz........................................... $\quad 17$

Scheelite............................................ 17

Sphalerite............................................. 17

Sylvanite....................................... 17

Spectroscopic examination.................................. 18

Crystallized ferberite.................................... $\quad 19$

Composition of ferberite and other members of the wolframite series..... 19

Definition of ferberite and other members of the wolframite series....... 37

The excess of ferrous oxide and manganous oxide.................. 38

Crystallography of ferberite from Boulder County, Colo., by Waldemar T. Schaller............................................ 40

Previous publications................................... $\quad 40$

General characters of the crystals ............................. 40

Mode of occurrence.................................. $\quad 40$

Size................................................. 41

Color and cleavage..................................... $\quad 42$

The measured crystals by localities. . ......................... 42

Axial elements........................................... 43

Calculation of values.................................... 43

Comparison of values................................... 45

Forms and angles....................................... $\quad 46$

New forms............................................ 47

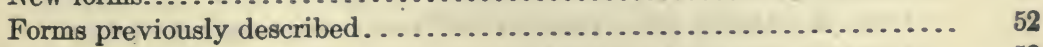

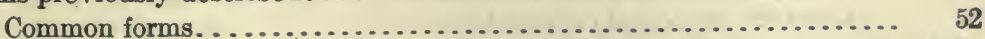

Rare forms 
Crystallography of Ferberite from Boulder County, Colo.-Continued. Discussion of the prism zone..................................

Habit................................................. ${ }_{56}$

Combinations............................................. 60

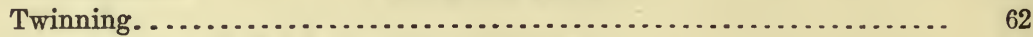

Description of measured crystals................................ 65

Form system of the wolframite group.......................... 69

Critical study of forms.................................. 69

Forms and coordinate angles............................... $\quad 71$

Combinations observed on the wolframite group................. 73

Bibliography............................................ 74

\section{ILLUSTRATIONS.}

Plate I. A, Ferberite inclosing finely brecciated granite, from Rogers tract, Nederland, Colo.; $B$, "Peanut ore," ferberite inclosing finely brecciated pegmatite, from the Conger mine, Nederland, Colo....

II. Brecciated granite and pegmatite cemented by ferberite, from Town Lot mine, Nederland, Colo................................

III. Brecciated ferberite vein, showing crystals formed since brecciation, from Conger mine, Nederland, Colo........................

IV. $A$, Cut and polished crystal of brown ferberite from Winnebago claim, near Rollinsville, Colo.; $B$, Brecciated ferberite vein from the Conger mine, Nederland, Colo..........................

V. Vug in a ferberite vein nearly filled by scheelite, the cavity then remaining being filled by quartz...........................

VI. $A$ and $B$, Thin sections of ore showing hamlinite (?), from Eagle Rock mine, 8 miles west of Boulder, Colo....................

Page.

VII. $A$, Wedge-shaped ferberite crystals from the Lone Tree mine, Nederland, Colo.; $B$, Wedge-shaped ferberite crystals from the Hoosier mine, Nederland, Colo.................................

VIII. A, Crystallized ferberite from the "Crow patent," Nederland, Colo.; $B$, Crystallized ferberite from the Georgia A. mine, Nederland, Colo...............................................

IX. Crystallized ferberite with elongated rhombic crystal faces, from the Nugget mine, Gilpin County, Colo........................

$\mathrm{X}$. Crystallized ferberite with elongated rhombic crystal faces, from the Nugget mine, Gilpin County, Colo.: $A$, Edge view; $B$, Side view..

XI. Ferberite with rhombic crystal faces, from the Nugget mine, Gilpin County, Colo.......................................

XII. Very fine specimen of ferberite with rhombic crystal faces, from the Nugget mine, Gilpin County, Colo.........................

XIII. $A$, Section of hübnerite from the Dragoon Mountains, Ariz., showing zonal structures; $B$, Photomicrograph of granite from the Whetstone Mountains, Ariz., showing wolframite with warty protuberances of scheelite along its edges............................

XIV. Section of wolframite from Irish Creek, Va., showing interstitial scheelite............................................ 
FIgURE 1. $A$, Orthographic projection of crystals with similar combinations, in parallel grouping, joined by the $\underline{a}$ (100) faces; $B$, Same with dissimilar combinations.

Page.

2. Superposed crystals, joined by the $c(001)$ faces................

3. Long, narrow, wedge-shaped crystal of habit $1 . . . \ldots \ldots \ldots \ldots . . . . .$.

4. Short, prismatic, somewhat flattened crystal of habit $2 . . . \ldots \ldots$.

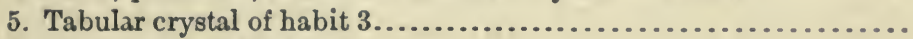

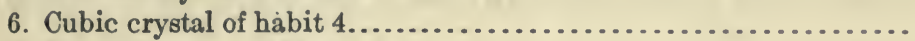

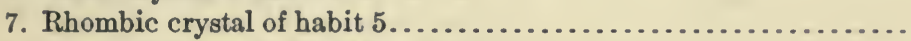

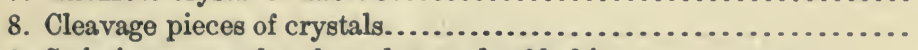

9. Striations on wedge-shaped crystals of habit $1 \ldots \ldots \ldots \ldots \ldots \ldots \ldots . \quad 59$

10. Crystal No. 4, wedge-shaped habit...................... 59

11. Peculiar shape of wedge-shaped habit caused by cleavage........ $\quad 59$

12. Crystal of short prismatic, somewhat flattened habit.......... 59

13. Crystal of rhombic habit, nearly equidimensional............. 59

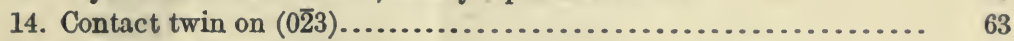

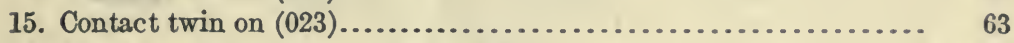

16. Line of contact of two contact twins..................... 63

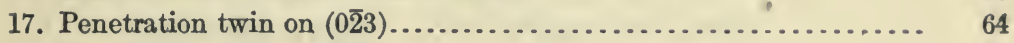

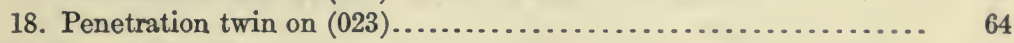

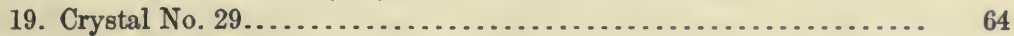

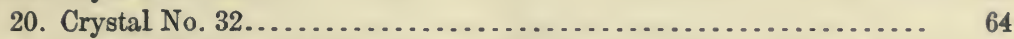

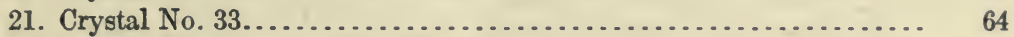

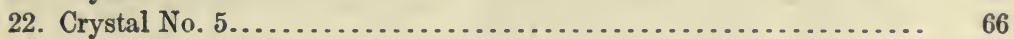

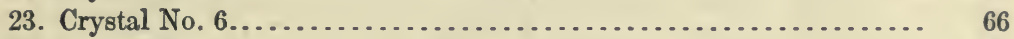

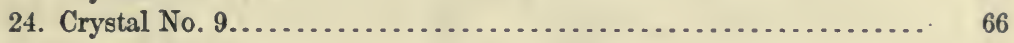

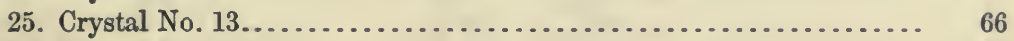

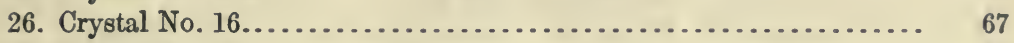

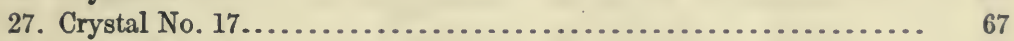

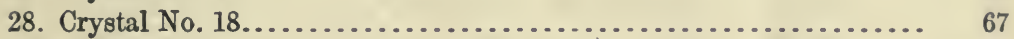

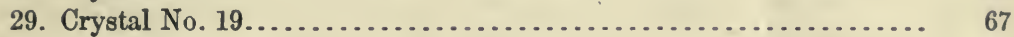

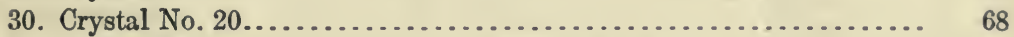

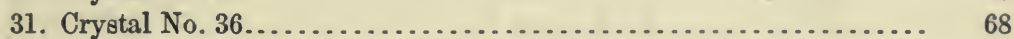

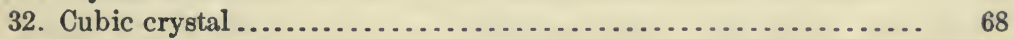

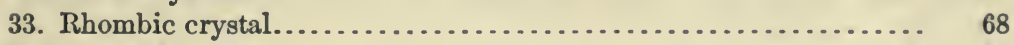

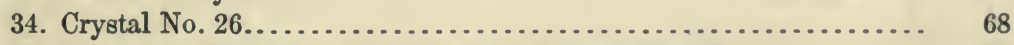

35. Gnomonic projection of forms of the wolframite group......... 70 



\title{
COLORADO FERBERITE AND THE WOLFRAMITE SERIES.
}

\author{
By Frank L. Hess and Waldemar T. Schaller.
}

THE MINERAL RELATIONS OF FERBERITE.

By Frank L. Hess.

\section{GEOGRAPHY AND PRODUCTION.}

Ferberite, as ordinarily defined, is that mineral of the wolframite series which is composed wholly or almost wholly of iron tungstate and which, like other wolframites, crystallizes in the monoclinic system. It is comparatively rare and in most places wherefound it seems to occur in small quantities only. It occurs in largest quantity in Colorado, about 25 miles northwest of Denver, mainly in Boulder County, though the deposits extend a short distance southward beyond the county line into the north end of Gilpin County. From this area, which has a southwest-northeast length of about 12 miles and a width of 6 to 7 miles, an equivalent of probably 7,300 short tons of concentrates carrying 60 per cent $\mathrm{WO}_{3}$ had been mined from 1901, when exploitation of the tungsten veins began, to the close of 1912.

The relative importance of the Boulder tungsten field, as the area is generally known, is indicated by the statistics of the production of tungsten ore in 1910, in which year the output of the field was 1,221 tons. In the same year the output of Queensland was 1,145 tons; Portugal, 1,132 tons; Argentina, 1,061 tons; and the world's production was probably about 7,500 tons, the remainder being smaller lots from many countries. ${ }^{1}$ The tungsten-bearing mineral produced from the three countries named was wolframite, and no other country produced any considerable quantity of ferberite.

1 Far details see Hess, F. L., Tungsten: U. S. Geol. Survey Mineral Resources, 1910, pt. 1, p. 734, 1911. Since the above paragraph was written the world's statistics for 1911 and 1912 have become available, and these show that Burma has outstripped all other producers, its output of woliramite being equivalent to 2,095 short tons of ore carrying 60 per cent WO3. (See U. S. Geol. Survey Minaral Resources, 1911 and 1912.) 


\section{CHARACTERISTICS OF THE FERBERITE.}

Ferberite occurs in the Boulder County field not only in large quantity, but in places in clean, beautifully developed crystals, and very commonly in small crystals coated with foreign material. The ferberite found over most of the field is jet black, but in a few places it is brown. It is opaque even in thin sections prepared for microscopic examination, and the clean crystals and cleavage faces are generally lustrous black.

The ferberite of Boulder County is very resistant to weathering and forms placers which have been successfully worked. The ferberite of the Black Hills (see analysis 81 , pp. 32-33) decays, leaving a skeleton of hydrous iron oxide, and wolframites that are close to ferberite in composition decay similarly, but no alteration has been noted in the ferberite of the Boulder field, although it is in many places coated and discolored by hydrous iron oxide and other minerals.

The other physical characteristics accord fairly well with those given by Dana ${ }^{1}$ for the wolframites. The cleavage along $b$ is perfect, and in some specimens a parting is shown parallel to $a$, but I have not noticed the parting parallel to $t$ (102) mentioned by Dana. The fracture is uneven and the mineral is brittle. Its streak and powder are dark brown-nearly black-and its hardness is about 5. Its specific gravity, as determined on selected crystals, is 7.499 .

A splinter of pure material fuses to a globule which has a crystalline surface and is not magnetic. The brown mineral from the Rogers tract is almost infusible before the blowpipe, and is strongly magnetic after heating.

Although ferberite is not very soluble in acids, if it is finely powdered and boiled a few minutes with concentrated hydrochloric acid it gives a solution which, on the addition of zinc, readily shows a characteristic blue color, followed by the almost equally characteristic violet and brown.

\section{GEOGRAPHY AND GEOLOGY OF THE BOULDER DISTRICT.}

Nederland, the commercial town of the Boulder tungsten field, lies 2 miles east of Cardinal station, on the Denver, Boulder \& Western Railroad, and 4 miles north of Rollinsville, on the Denver, Northwestern \& Pacific Railway.

The ferberite-bearing area lies on an elevated plateau, above which, on the west, rise massive and imposing peaks. The altitude at Nederland is 8,237 feet. On the east an abrupt scarp descends from the plateau to the Great Plains. Streams draining the plateau have cut deep canyons extending back from the scarp to distances determined by the abrading power of the streams. 
Biotite-hornblende granite, in some places gneissoid, granitic gneiss, and quartz-mica schist form the country rocks. The gneiss and schist are older than the granite, and all three are of pre-Cambrian age and are cut by later dikes that range in composition from limburgite to granite pegmatite.

Dynamic metamorphism has in places made the granite, gneiss, and schist difficult to differentiate. Some of the dikes are also more or less squeezed. The gneiss is believed by R. D. George ${ }^{1}$ and Edson $\mathrm{S}$. Bastin ${ }^{2}$ to be of sedimentary origin. The pegmatites show only a little crushing and carry few metallic minerals.

\section{OCCURRENCE, VEIN SYSTEMS, AND RELATIONS.}

The ferberite occurs in a group of veins which in general extend from southwest to northeast, though individual veins strike toward nearly every point of the compass.

On the northwest and southwest sides of the tungsten-bearing area are gold and silver bearing veins having the same general trend as the tungsten veins. The veins carrying the precious metals are a continuation of the gold-bearing belt of Clear Creek and Gilpin counties. ${ }^{3}$

Two types of veins carry the gold and silver-those in which the minerals are mostly sulphides and those in which the gold occurs as a telluride, ${ }^{4}$ The sulphidic veins are in general quartz veins carrying gold and silver bearing sulphides, such as pyrite, galena, chalcopyrite, and zinc-blende. Silver predominates. The telluridic veins ${ }^{5}$ occur in sheeted zones and eontain only a little quartz. They carry gold mostly in a telluride, which is probably sylvanite, and the gold predominåtes over the silver. Pyrite, molybdenite, a vanadium mineral allied to roscoelite, barite, adularia, and chalcedony accompany the telluride. The veins are thin and commonly frozen to the walls.

The ferberite veins are more or less connected with the gold veins, as might be expected from the general grouping, and their connection with the telluridic veins seems closer than with the sulphidic veins. Specimens from Magnolia, at the southeastern edge of the field, showed both gold telluride and ferberite, but it could not be determined which was the older. George reports a like specimen in which the telluride was evidently the older mineral. ${ }^{\circ} \mathrm{He}$ also reports the occurrence of the two minerals in the Wheelmen Tunnel, in Boulder Canyon, ${ }^{6}$ and at Sunshine, on the northern nge of the field. A speci-

\footnotetext{
1 George, R. D., The main tungsten area of Boulder County, Colo.: Colorado Geol. Survey First Rept., pp. 19-20, 1909.

2 Oral statement.

Lindgren, Waldemar, Some gold and tungsten deposits of Boulder County, Colo.: Econ. Geology, vol.

2, p. $453,1907$.

'Idem, pp. 456-457.

${ }^{5}$ Idem, pp. 457-459.
}

- George, R. D., op. cit., p. 76. 
men from Ward, still farther north and beyond the territory which up to this time has been productive, shows a wolframite which is probably not ferberite and which occurs in long, slender crystals of a habit totally different from that of the ferberite of the main tungsten area. Embedded with this mineral in white quartz are pyrite and chalcopyrite, apparently of the same general age, though the chalcopyrite is of later deposition, as it is pierced by the wolframite. The ore is said to carry both gold and silver. Although the data at hand are not very extensive, it seems probable that the connection between the three classes of veins may be fairly close and that there may not be a great difference in the ages of the several types. The manganese content of the tungsten mineral seems to increase somewhat progressively across the field from the Gilpin County line to Ward-that is, from south to north. A few miles south of the tungsten field in Gilpin County pitchblende has been found in considerable quantity in close connection with gold and silver bearing veins, which lie in the same mineral belt. Forbes Rickard has recently noted ${ }^{1}$ a close relationship between the ferberite veins of Boulder County and the pitchblende veins of Gilpin County.

The ferberite veins much resemble those carrying gold telluride. They occur in sheeted or crushed zones and are reticulated, the individua veins ranging from a small fraction of an inch to several inches in thickness, while the ore-bearing body may reach a width of 14 feet, as in the Philadelphia mine of the Wolf Tongue Mining Co. The veins cut granite, gneiss, and pegmatite, and though the ore may extend from the granite into the gneiss it may be cut off at the contact, its continuity depending on local conditions, but there are only a few productive veins in the gneiss.

\section{CHARACTERISTICS OF THE ORE.}

The amount and character of gangue in the veins differ greatly in different parts of the field. Quartz, the universal vein mineral, occurs in much less quantity in the ferberite veins than in most veins. Only a very little visibly crystallized quartz in the ferberite veins has come to my attention. There is, however, in most if not in all of the veins of the northeastern part of the field, and in many of the wider veins of the southwestern part of the field, a very fine grained gray or brown quartz, known as "bone," which has a fracture much like that of chalcedony and which is largely a replacement of the country rock. The ferberite in the northeastern half of the field appears to be less well crystallized than in the southwestern half. It occurs in some of the veins in minute particles mixed with quartz (see Pl. VI, p. 15), so that in many places the ore is difficult to concentrate, although the

1 Pitchblende from Quartz Hill, Gilpin County, Colo.: Min. and Soi. Press, June 7, 1913, p. 852. 


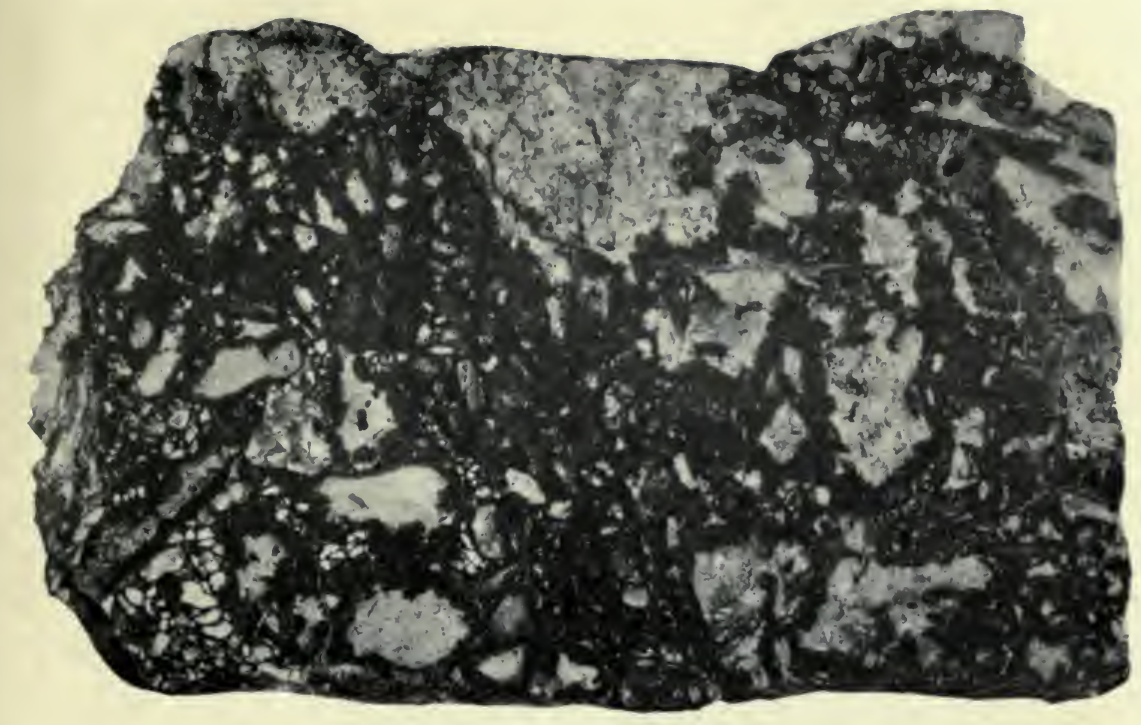

A. FERBERITE INCLOSING FINELY BRECCIATED GRANITE.

From Rogers tract, Nederland, Colo. Natural size.

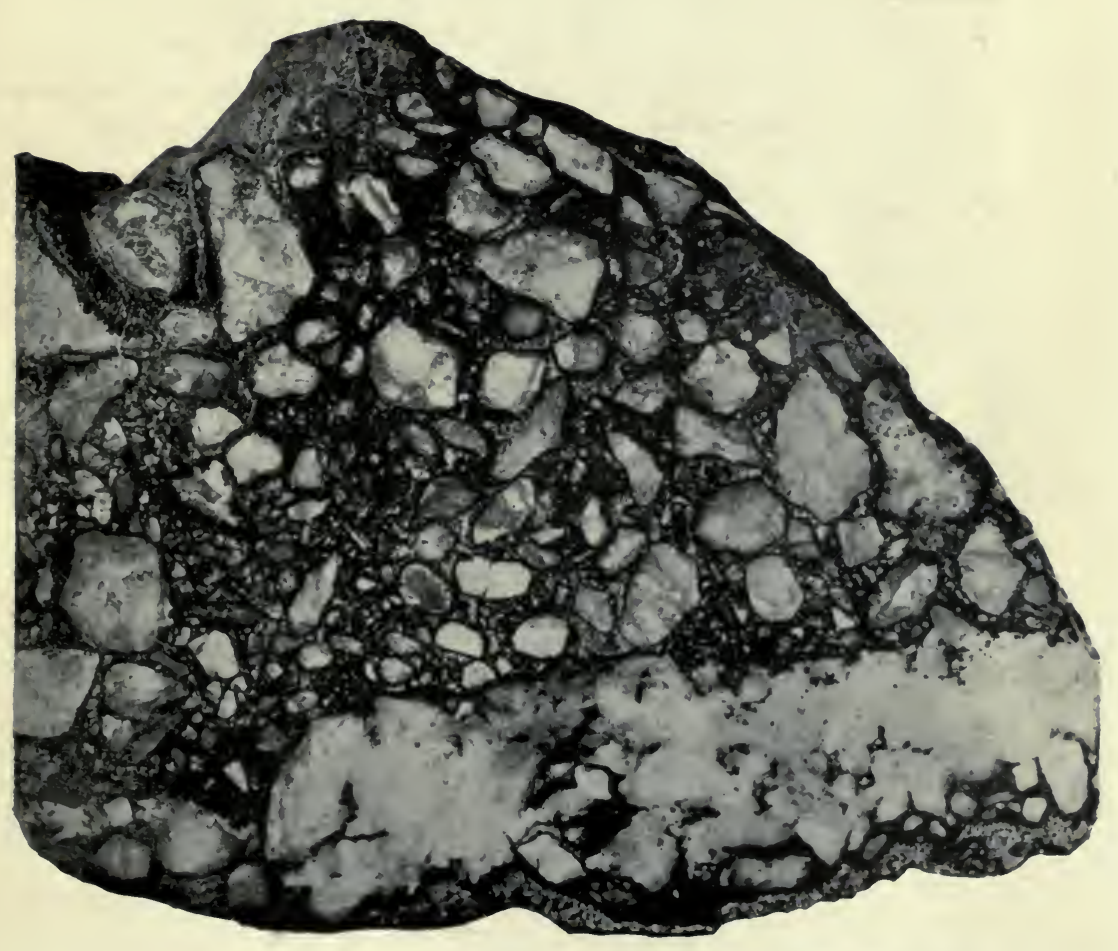

B. "PEANUT ORE," FERBERITE INCLOSING FINELY BRECCIATED PEGMATITE.

From the Conger mine, Nederland, Colo. Natural size. 


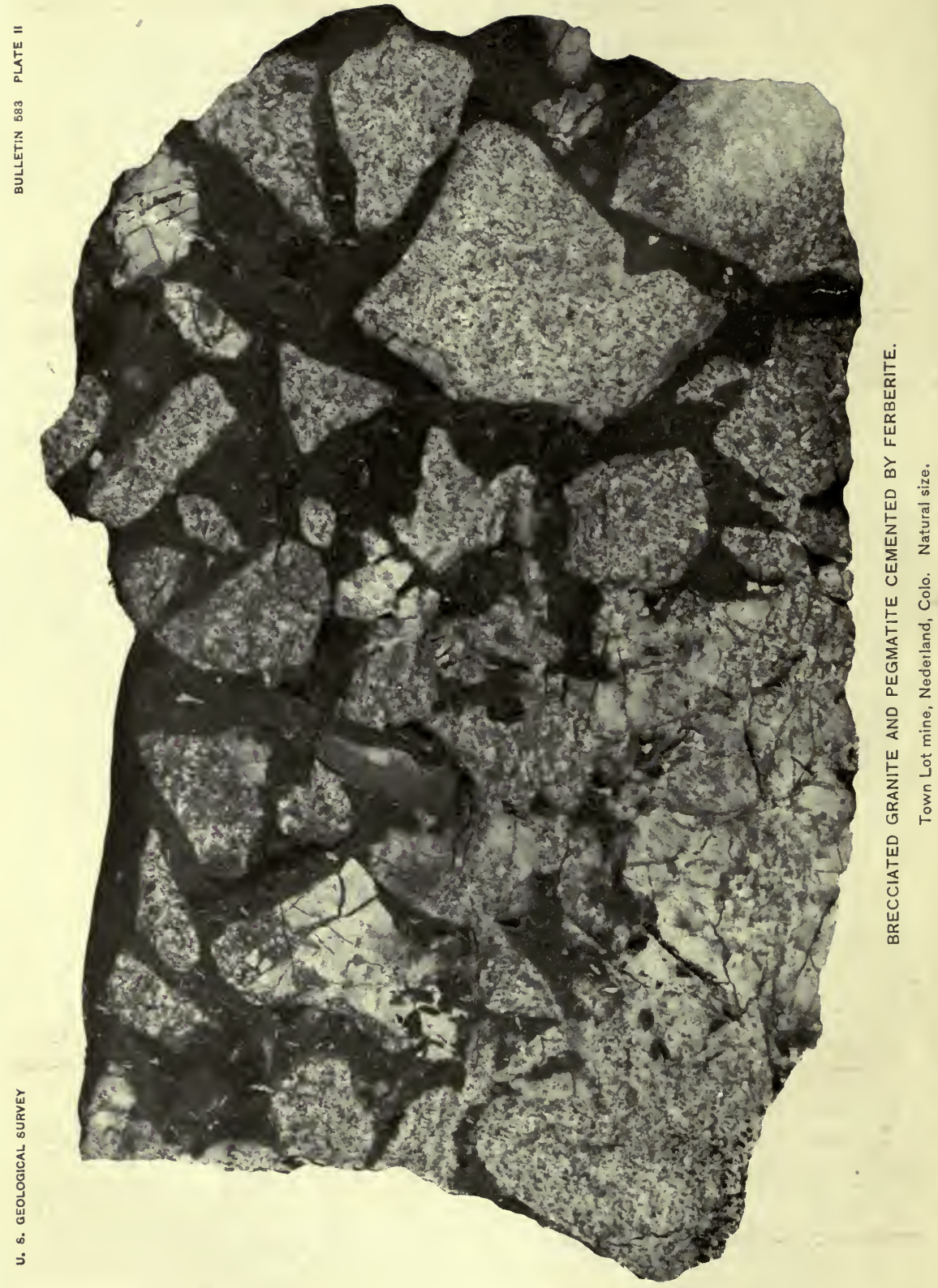


total percentage of $\mathrm{WO}_{3}$ may be as high as or higher than that in ores which are easily and profitably worked.

In the southwestern part of the field the narrower individual veins are made up almost wholly of ferberite, which has grown from both sides of the crevices and forms combs of small crystals that coalesce at their bases. The combs are of fairly uniform thickness, so that although in the narrower crevices they may have met and grown together, in the wider cracks they form bristling crusts of crystals on each side. In places these crystals are clean and bright but generally very small, from one to three thirty-seconds of an inch (1 to 2 millimeters) across. Most of the crystals are covered with a coating of impure chalcedony, which in some specimens is mixed with opal and. in others contains much iron. The coating generally includes small crystals of ferberite, which are of course of a later generation than those on the walls. Some vugs 3 or 4 inches across are entirely filled with such a mixture.

On the Nugget claim, $3 \frac{1}{2}$ miles southeast of Nederland, the crusts of nearly pure ferberite reach a thickness of more than an inch, and this claim has produced the finest crystallized specimens of ferberite yet found. In the veins of this claim, as in the others, most of the crystalline aggregates are covered with a siliceous mixture, which here carries much brown iron oxide. The veins cut a moderately coarse grained pégmatite and have so far produced only a small quantity of ore. The Winnebago, an adjoining claim, has produced some small specimens of crystallized ferberite from similar veins.

In places the country rock instead of being sheeted is crushed into smaller, more nearly equidimensional fragments, which may not be over one-eighth inch (3 millimeters) in diameter. Ore in which fragments of rock no larger than half an inch (13 millimeters) across are embedded in ferberite is popularly known as "peanut" ore, from its resemblance to peanut candy. (See Pl. I.) The fragments of the breccia vary greatly in size (Pl. II), and where the fragments are larger the breccia is characterized by vugs lined with ferberite crystals. Both finely and coarsely brecciated ore is typical of the veins of the district. Many of the veins have been opened several times, sa that the ferberite itself is brecciated. (See Pls. III and IV, B.)

In places the ferberite carries considerable manganese and grades into wolframite. The mineral from Gordon Gulch carries almost 6 per cent $\mathrm{MnO}$ (analysis 58, pp. 30-31) and wolframite occurs on the north side of the field at Ward (analysis 49). The only other tungsten mineral so far identified in the field is scheelite, which occurs in small quantity as a thin coating of octahedral nearly white crystals about one thirty-second inch (1 millimeter) in thickness, over a film of ferberite covering the walls of crevices in the Sugar Loaf district in the northern-central part of the area. Vugs in ore from the Frigid Mining 
Co.'s claim at Crisman are lined with clear brownish and colorless scheelite crystals, the largest three thirty-seconds of an inch (2 millimeters) thick. Vugs in ore from the Rogers tract, near the center of the area, are lined with reddish-brown scheelite, which also occurs through the quartz in small quantity. Some of the vugs are of almost microscopic size. (See Pl. V.) As seems to be usual in tungsten deposits, the scheelite formed later than the mineral of the wolframite series, but it is not a secondary mineral. In cleaning certain ferberite crystals with hydrofluoric acid deep pits with rather regular outlines are made, accompanied by the formation of yellow tungsten trioxide, and it seems possible that the pitting may be due to the removal of scheelite.

\section{MINERALS ASSOCIATED WITH THE FERBERITE.}

Associated minerals, other than quartz, are few and scarce in the ferberite veins of the main part of the field. Near the gold-silver bearing areas there is of course a mixture of the minerals of the several vein groups.

The following minerals accompany ferberite in the veins:

Adularia.-Adularia forms a coating one-sixteenth of an inch (2 millimeters) thick on the walls of the Black Hawk No. 2 vein, $1 \frac{1}{2}$ miles south of Nederland. It is beneath most of the ferberite, but was probably deposited with the first of the ferberite. Adularia in microscopic grains is found in many of the veins.

Calcite. - The gangue in the Conger mine carries microscopic particles of a carbonate, which is probably calcite.

Chalcedony.-Chalcedony mixed with more or less opal and hydrous iron oxide coats crystals from many of the veins.

Chalcopyrite.-Chalcopyrite occurs at Ward in veins carrying some wolframite, which seems to approach ferberite in composition, though no analysis of the mineral is at hand.

Galena.-George ${ }^{1}$ reports the occurrence of galena and sphalerite in veins with ferberite near Magnolia. The galena is said to occur generally in minute cubes but in considerable quantity.

Gold and silver.-Gold and silver are reported to occur in some of the ferberite veins other than those in which sylvanite is present. In the ore seen which is said to be gold-bearing small quantities of sulphides are present and the gold is probably associated with the pyrite. Hills ${ }^{2}$ states that eight assays of concentrates gave an average of 0.01 ounce of gold to the ton.

Greenawalt ${ }^{3}$ gives three analyses of concentrates which carried silver in quantities of $1.2,2.4$, and 3.1 ounces to the ton. The speci-

1 George, R. D., The main tungsten area of Boulder County, Colo.: Colorado Geol. Survey First Rept., p. $75,1909$.

Hills, V. G., Tungsten mining and milling: Colorado Scl. Soc. Proc., vol 9, p. 150, 1909.

8 Greenawalt, W. E., The tungsten deposits of Boulder County, Colo.: Eng. and Min. Jour., vol. 83, p. $951,1907$. 


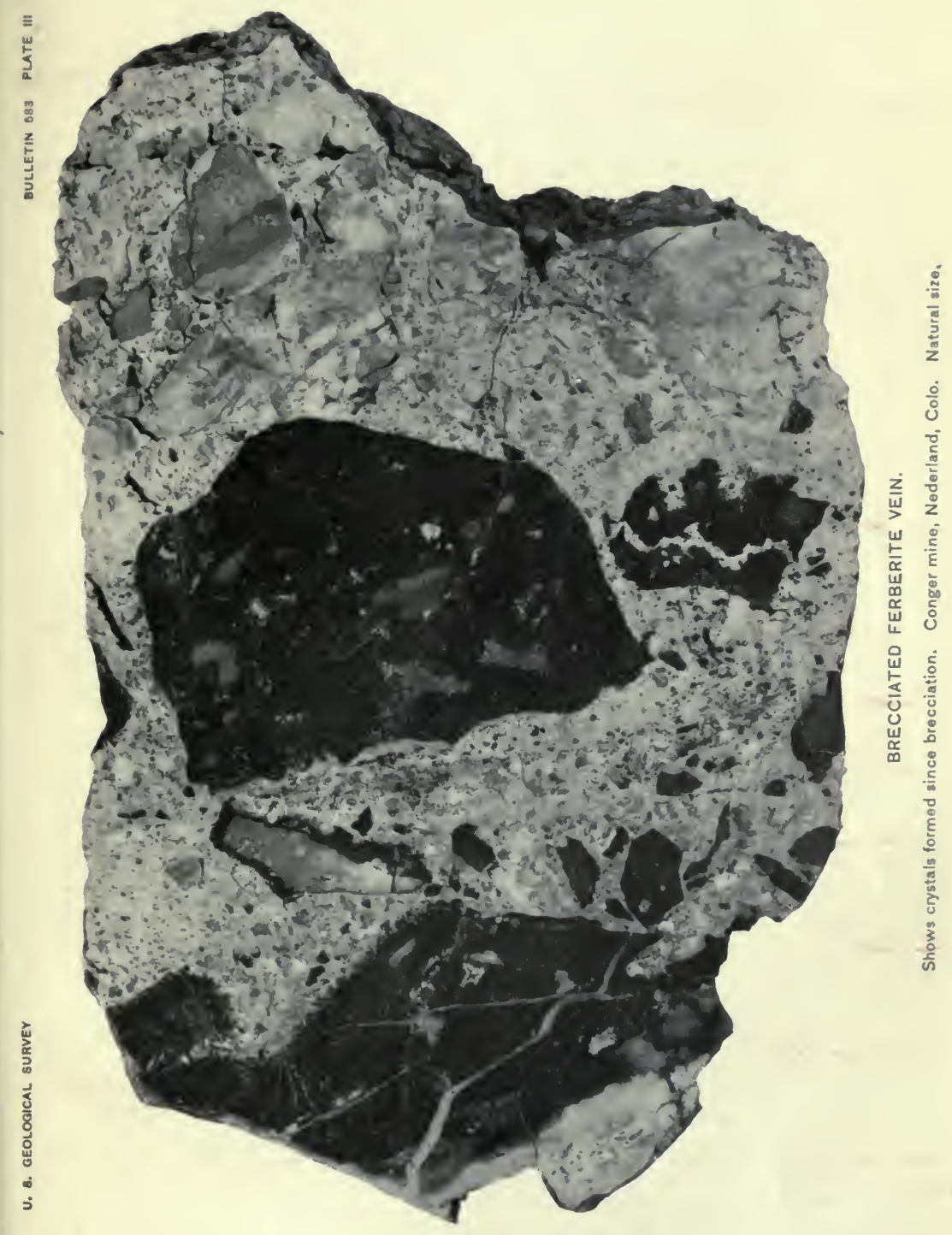




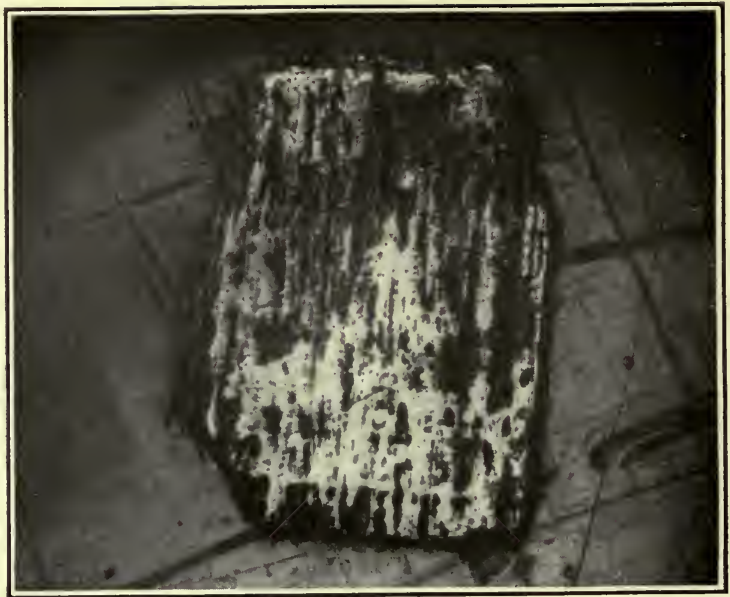

A. CUT AND POLISHED CRYSTAL OF BROWN FERBERITE.

From Winnebago claim near Rollinsville, Colo. Shows spongy structure of the ferberite, the pores of which are filled with hydrous iron oxide. $\times 78$.

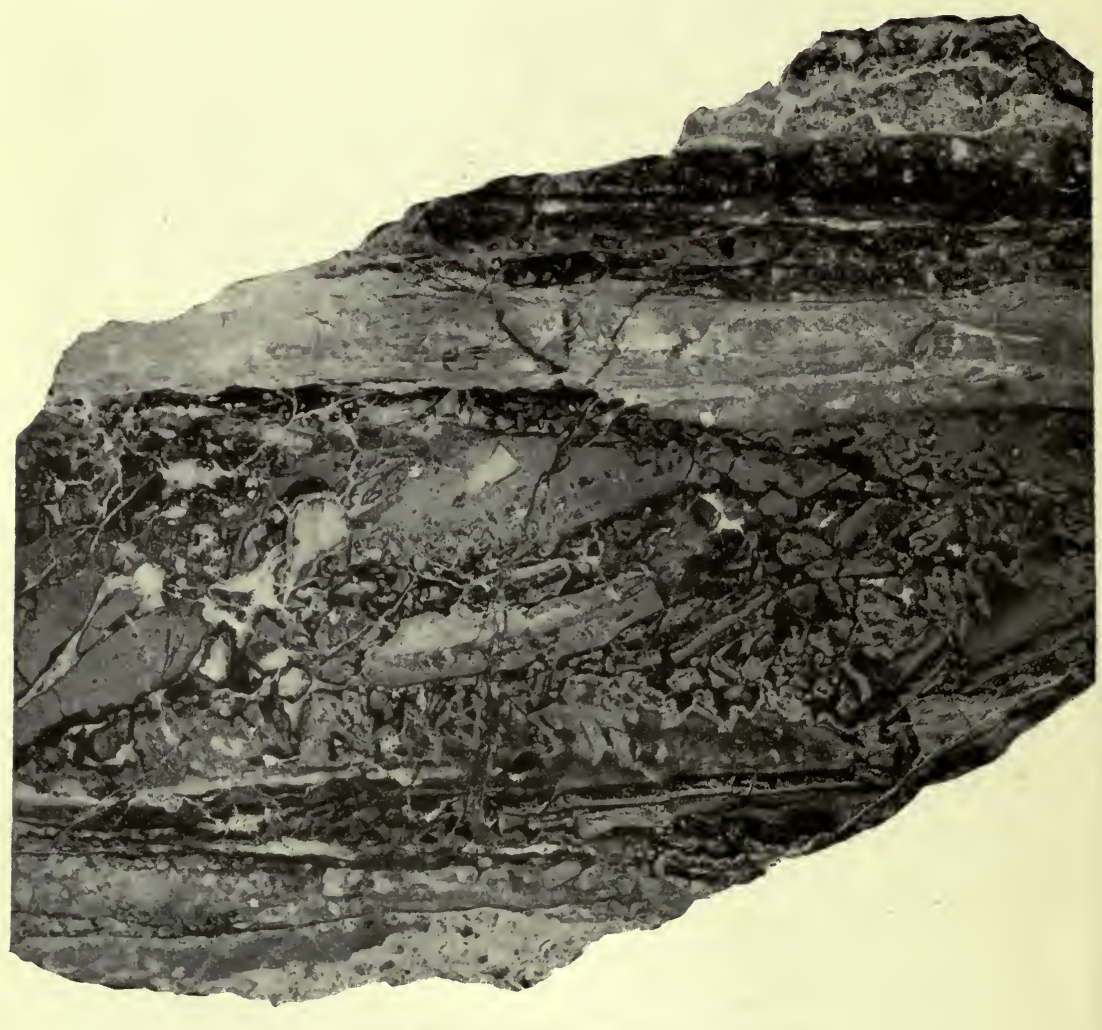

B. BRECCIATED FERBERITE VEIN.

From the Conger mine, Nederland, Colo. Both the black and the gray edging it are ferberite, the difference in color being due to the orientation of the crystals. Natural size. 
mens came respectively from Beaver Creek, Nederland, and Gordon Gulch. Tomblin ${ }^{1}$ states that in the Logan mine at Crisman free gold is sometimes found with ferberite.

The occurrence of small quantities of gold and silver in tungsten veins is fairly common, but in many if not most veins the precious metals, though of the same general period of vein formation, are probably of later deposition than the wolframite.

Silver seems to occur in greater quantity with the wolframites than does gold, and gold in greater proportional quantity with scheelite, but this can not be stated as an invariable rule.

Hübnerite is found near Pony, Mont., in quartz veins which have been worked for silver; in veins prospected for silver but not rich enough to work near Ellsworth, Mammoth district, Nye County, Nev. (the name hübnerite was given by Riotte to the mineral from this place); at Butte, Mont., ${ }^{2}$ on the 300 -foot level of the Gagnon mine, where hübnerite "formed an oreshoot of argentiferous material;" in the Birdie mine 4 miles east of Butte (of very light brownish-yellow color) $;^{3}$ with silver minerals in the Combination mine, Philipsburg, Mont. $;^{4}$ in the mines of Silverton, Colo. ${ }^{5}$ (wolframite also); and Tonopah, Nev. ${ }^{6}$ Wolframite occurs with silver ore in the Tip Top mine, Tip Top district, near Columbia, Ariz.; in a prospect of A. C. Young's at Old Hachita, N. Mex.; ${ }^{7}$ in the Victorio district, N. Mex.; ${ }^{8}$ in the Sonoma Range, 15 miles south of Golconda, Nev.; at Silver Mines, 10 miles southeast of Ironton, Mo. $;^{9}$ and on the Silver Comet and other claims southwest of Pioche, Nev. Wolframites are also found with deposits carrying more gold than silver in the South Homestake mine, White Oaks, N. Mex.; ${ }^{10}$ gold quartz veins on Sheep Creek near Salmo, British Columbia; ${ }^{11}$ and gold mines of Lead, S.Dak.; and at Cave Creek, Ariz., auriferous pyrite occurs with ferberite.

1 Tomblin, M. B., Tungsten; history, occurrence, uses: Facts concerning tungsten mining in world's greatest freld, Boulder County, Colo.: Boulder County Metal Mining Association Bull. No. 3, 1912.

2 Weed, W. H., Geclogy and ore deposits of the Butte district, Mont.: U. S. Geol. Survey Prof. Paper 74, p. 80, 1912. See also, Pearce, Richard, The association of minerals in the Gagnon vein, Butte City, Mont.: Am. Inst. Min. Eng. Trans., vol. 16, p. 64, 1888.

Tomek, F., Tungsten in Montana: Min. World, vol.28, p. 68, 1908.

4 Goodale, C.W., and A kers, W. A., Concentration before amalgamation for low-grade partially decomposed silver ores, with notes on the geology of the Flint Creek mining district: A m. Inst. Min. Eng. Trans., vol. 18 , p. $248,1890$.

-Ransome, F. L., A report on the economic geology of the Silverton quadrangle. Colo.: U. S. Geol. Survey Bull. 182, pp. $86-87,256,1901$.

- Eakle, A. S., The minerals of Tonopah, Nev.: California Univ. Dept. Geology Bull., vol. 7, 1912, p. 18. Prof. Eakle calls the mineral wolframite, but states "some of them [the crystals] are exceedingly thin and almost transparent, with a deep-red color." This corresponds with a specimen in my possession and seems to indicate hübnerite rather than wolframite.

${ }^{7}$ Lindgren, Waldemar, and others, The ore deposits of New Mexico: U. S. Geol. Survey Prot. Paper 68, p. $336,1910$.

Idem, p. 292.

-Haworth, Erasmus, A contribution to the Archean geology of Missouri: Am. Geologist, vol. 1, pp. 294$295,1888$.

10 Graton, L. C., U. S. Geol. Survey Prof. Paper 68, p. 180, 1910. See analyses 4 and 16, p. 24.

11 Walker, T. L., The occurrence of tungsten ores in Canada: Canadian Min. Inst. Jour., vol. 11, pp. 367-371, 1908; Report on the tungsten ores of Canada: Canada Dept. Mines, Mines Branch, p. 37, 1909. 
In 1907 a lot of wolframite ore, weighing 1.1 long tons, from Ravensthorpe, Western Australia, carried 66.2 per cent $\mathrm{WO}_{3}$ and yielded 5.3 ounces of gold. ${ }^{1}$

Examples might be multiplied but would add little weight. The importance of those given lies in their bearing on the genesis of tungsten, gold, and silver ores. In many places tungsten ores are closely connected with pegmatites or lie in the pegmatites themselves and are probably in nearly all places close to a magmatic source. The gold and silver found in the deposits must be likewise near their place of origin. Of course, it is not to be argued that the absence of tungsten minerals implies that the gold and silver may not be near a magmatic source, but gold and silver appear to accompany siliceous solutions much farther from their igneous source than do tungsten minerals. It seems probable that the tungsten minerals may be deposited from the hotter waters emanating from magmas, and silver and gold from the solutions after they have somewhat cooled.

Hamlinite (?). - In sections cut for microscopic study from a specimen obtained at the Eagle Rock mine many small, very light green fragments of a uniaxial, optically positive mineral were found. As determined by E. S. Larsen, its indexes of refraction are $\omega=1.620 \pm$ $0.003, \varepsilon=1.630 \pm 0.003$. Its birefringence is 0.010 , but some basal sections show anomalous birefringence as though divided into segments. It has a perfect basal cleavage and shows a slight zonal growth. The particles show a tendency toward square sections, and the optical properties suggest that the mineral belongs to the alunitehinsdalite series. Although very small, the particles are numerous, forming perhaps 10 to 25 per cent of the bulk of this particular ore. (See PI. VI.) The gangue is "horny" quartz through which are distributed particles of ferberite and certain other particles which are attracted by a magnet, probably magnetite, both of which occur in grains almost as small as the unknown mineral. An attempt was made to separate the mineral from its gangue by grinding it very fine and passing the powder through a Thoulet solution of 2.8 specific gravity, but the material was too much mixed with quartz to show sufficient improvement for analytical purposes. The fact that with the attached quartz it sank through the liquid indicates that its specific gravity is above 2.8, but it is probably not over 3. A partial analysis by George Steiger, in the chemical laboratory of the United States Geological Survey, showed the presence of aluminum, 2 per cent strontium, a very little sulphur as a sulphate, and 3.6 per cent phosphorus pentoxide. The only heary metals found were tungsten, iron, manganese, and a trace of titanium. Fluorine and chlorine were absent. There was only a questionable trace of calcium and a very small quantity of magnesium.

\footnotetext{
1 Simpson, E. S., and Gibson, C. G., The distribution and occurrence of the baser metals in Western Australia: Western Australia Geol. Survey Bull. 30, pp. 115-117, 1907.
} 


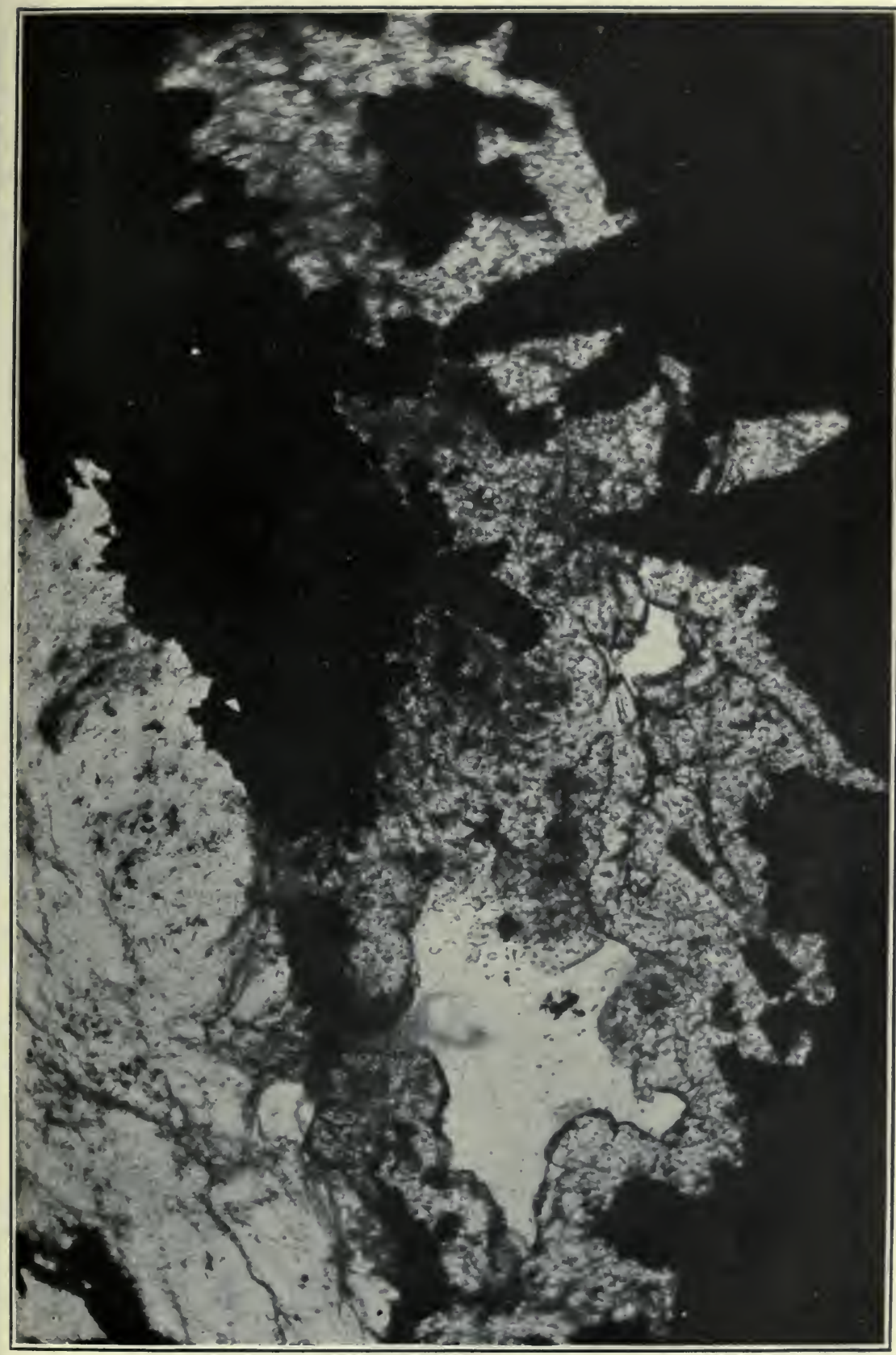




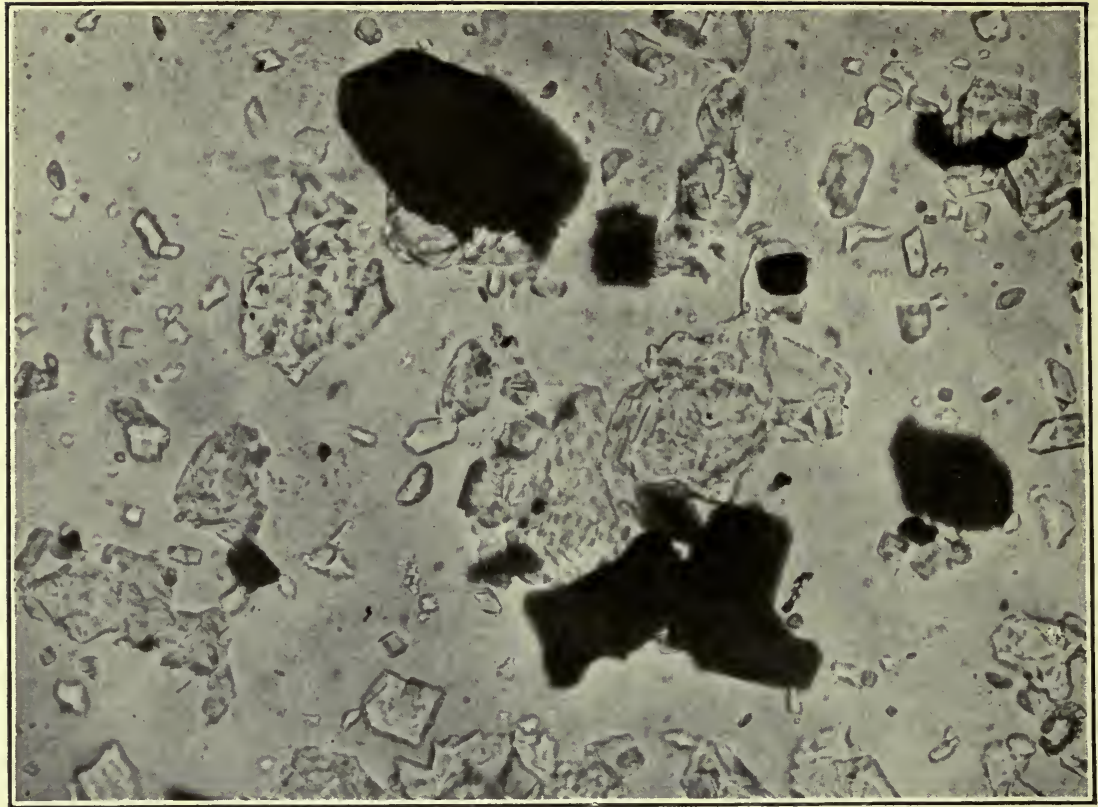

A.

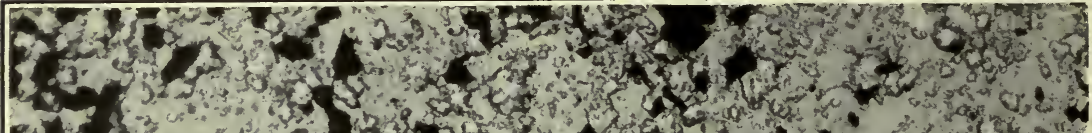

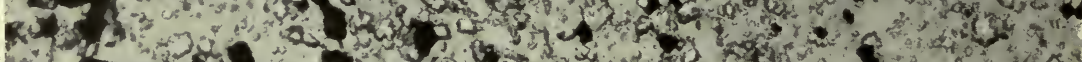

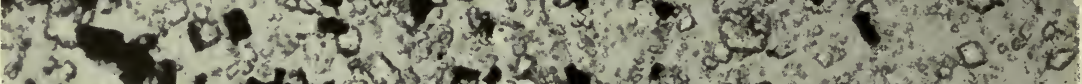

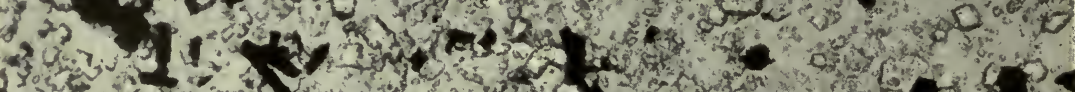

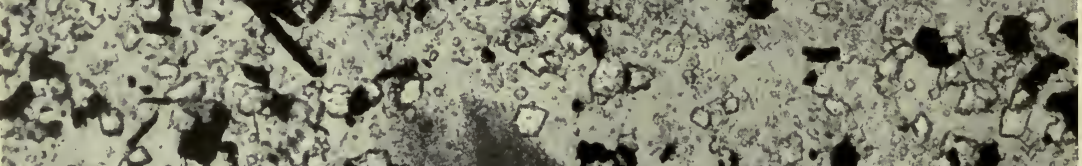

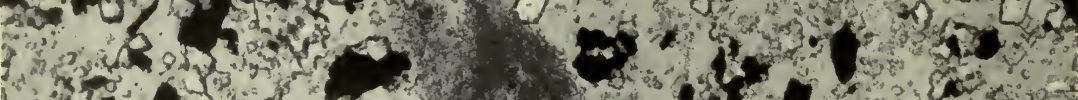

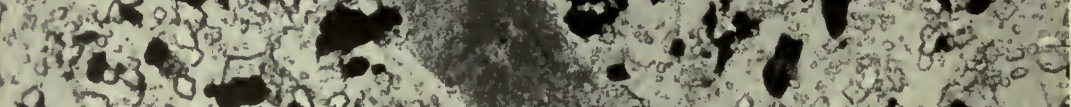

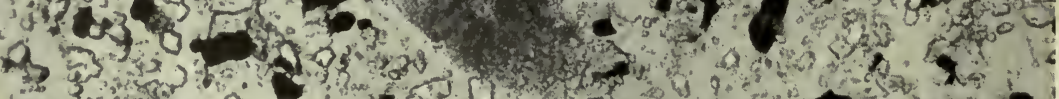

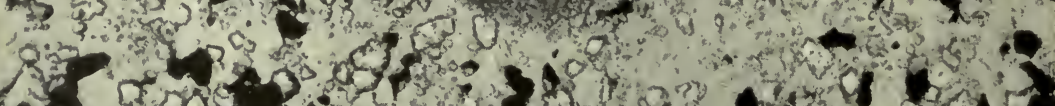

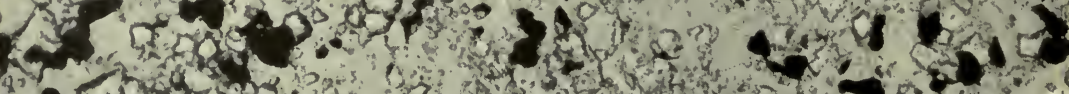

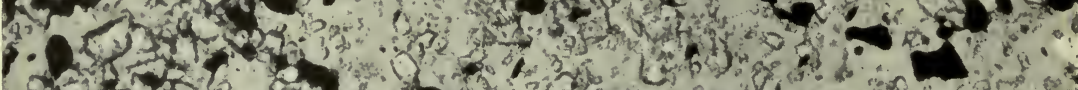

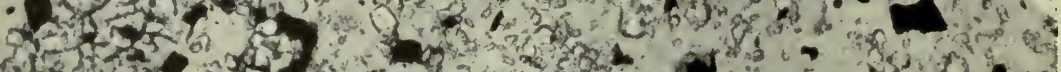

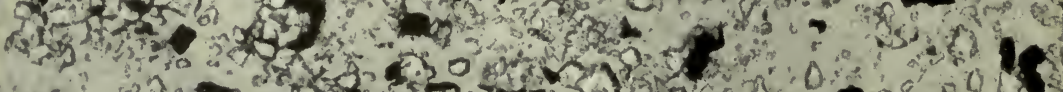

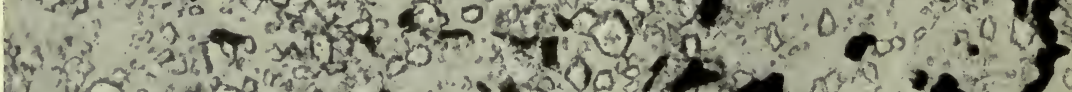

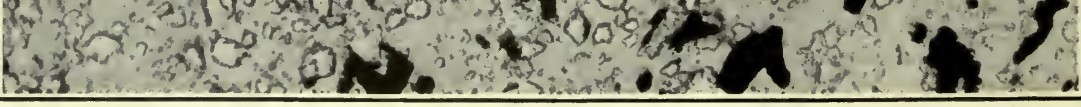


The mineral seems to be close to hamlinite, for which the formula, as recalculated by Prior, ${ }^{1}$ is $2 \mathrm{SrO} .3 \mathrm{Al}_{2} \mathrm{O}_{3} \cdot 2 \mathrm{P}_{2} \mathrm{O}_{5} .7 \mathrm{H}_{2} \mathrm{O}$, but as a little sulphur is present it probably belongs in the series between hamlinite and svanbergite $\left(2 \mathrm{SrO} .3 \mathrm{Al}_{2} \mathrm{O}_{3} \cdot \mathrm{P}_{2} \mathrm{O}_{5} \cdot 2 \mathrm{SO}_{3} \cdot 6 \mathrm{H}_{2} \mathrm{O}\right)$. Another mineral of the same group, hinsdalite $\left(2 \mathrm{PbO} \cdot 3 \mathrm{Al}_{2} \mathrm{O}_{3} \cdot \mathrm{P}_{2} \mathrm{O}_{5} \cdot 2 \mathrm{SO}_{3} \cdot 6 \mathrm{H}_{2} \mathrm{O}\right)$, was discovered in 1910 by Larsen ${ }^{2}$ as a vein mineral in the Golden Fleece mine, near Lake City, Colo.

The same mineral has been found in sections from other parts of the Boulder field, though not in such large quantity as in the Eagle Rock specimen. Sections of "hornstone" ore from other places have shown none of it. However, phosphorus in small quantity is nearly if not quite a universal component of the Boulder County tungsten ores.

Hugh F. Watts, who has assayed thousands of samples of ferberite ores and concentrates coming from all parts of the Boulder field, states that whenever he has tested for it he has found phosphorus present. $^{3}$ In one test on a composite of seven ores the phosphorus present amounted to 0.038 per cent. Hills ${ }^{4}$ notes from 0.01 to 0.02 per cent phosphorus in eight out of nine analyses of concentrates and a trace in the other. Greenawalt ${ }^{5}$ notes 0.05 per cent in a concentrate from Gordon Gulch. No apatite or other phosphate except the hamlinite (?) has been found, and it seems reasonable to suppose a very wide distribution of the hamlinite (?). The mineral apparently occurs only in the quartz gangue, and if the ore is finely ground before separation very little will be left in the concentrates, for its specific gravity (more than 2.8 and probably not higher than 3 ) is so low that it would readily pass into the tailings.

I hope to make further investigation of this mineral.

Hematite (specular).-At the south end of the Black Hawk No. 1 vein, $1 \frac{3}{4}$ miles south of Nederland, a short vein which is nowhere more than a few inches thick, the ferberite gives way to specular hematite. This mineral is also found in small quantity in some other veins, and what is known as the May vein, a short distance east of the Black Hawk No. 1 vein, is a series of anastomosing veinlets made up of specular hematite, which is said to be accompanied by a little tungsten, though none could be found in specimens collected. Hills ${ }^{4}$ gives an analysis of ferberite concentrates from "the east side of the district," in which the content of $\mathrm{FeO}$ exceeds that of $\mathrm{WO}_{3}$, and another in which the quantity of $\mathrm{FeO}$ is only a little less than that of $\mathrm{WO}_{3}$. ihe analyses follow.

1 Prlor, G. T., Hamlinite, plumbogummite (hitchcockite), beudantite, and svanbergite, as members of a natural group of minerals: Mineralog. Mag., vol. 12, p. 253, 1900.

Larsen, E. S., and Schaller, W. T., Hinsdalite, a new mineral: Am. Jour. Sci., 4th ser., vol. 32, p. 251, 1911.

3 Private communication.

4 Hills, V. G., Tungsten mining and milling: Colorado Scl. Soc. Proc., vol. 9, p. 149, 1909.

s Greenawalt, W. E., The tungsten deposits of Boulder County, Colo.: Eng. and Min. Jour., vol. 83, p. 951, 1907. . 
Analyses of tungsten concentrates treated at the Clarasdorf mill, near Boulder, Colo.

\begin{tabular}{|c|c|c|}
\hline 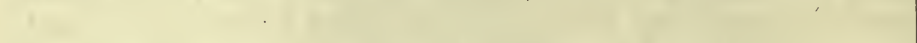 & 1 & 2 \\
\hline 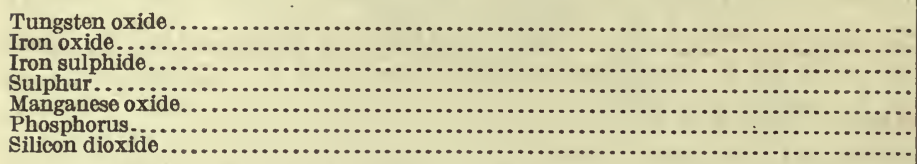 & $\begin{array}{r}38.46 \\
39.31 \\
.51 \\
.27 \\
3.10 \\
.01 \\
18.61\end{array}$ & $\begin{array}{r}38.59 \\
34.01 \\
2.59 \\
1.38 \\
2.67 \\
22.01\end{array}$ \\
\hline
\end{tabular}

The first analysis indicates a wolframite of the composition $\mathrm{MnWO}_{4}$, 26 per cent; $\mathrm{FeWO}_{4}, 74$ per cent-a composition close to that of the Gordon Gulch wolframite (analysis No. 58, p. 31). After satisfying the $\mathrm{MnO}$ present only 8.8 of the 39.31 per cent $\mathrm{FeO}$ given is required to combine with the $\mathrm{WO}_{3}$. The second analysis indicates a wolframite of the composition $\mathrm{MnWO}_{4}, 22.7$ per cent; $\mathrm{FeWO}_{4}, 77.3$ per cent. This composition requires for combination with $\mathrm{WO}_{3}$ only 8.7 of the 34.01 per cent $\mathrm{FeO}$. The form in which the iron is present is unknown, but the possibility that it may be specular hematite is at once suggested by knowledge of the occurrences mentioned. The sulphur shown in the analyses indicates, of course, that a small quantity of iron is present as pyrite.

Occurrences of specular hematite with wolframites are not unknown. At South Crofty mine, Cornwall, "the presence of specular iron has caused trouble in obtaining a high-class wolfram concentrate."1

It seems probable that deeper workings on the Rogers tract may show specular hematite, to the decomposition of which may be due the brown color of much of the ferberite from that tract.

Limonite.-Limonite, under which term are here included all hydrous oxides of iron, occurs in many veins, and nearly all the ore on the Rogers tract, about 2 miles northeast of Nederland, is stained brown with it. The crystals of ferberite are not only brown on the outside, but when broken show brown sections. (See p. 38 and Pl. IV, $A$, p. 13.) The origin of the limonite and its relationship to the ferberite are unknown, but in part at least it is possibly altered from specular hematite, as already stated. Iron-bearing carbonates occur in some tungsten deposits, notably the scheelite deposits of Atolia, Cal. Carbonates decompose much more easily than specular hematite, and one may have been originally inclosed in the ferberite of the Rogers tract and some other places.

Magnetite. -Magnetite is recorded by George ${ }^{2}$ as occurring with the ferberite. Magnetite seems to be a probable associate of ferberite,

1 Anon., Cornwall (editorial): Min. Mag., London, vol. 8, p. 165, 1913.

2 George, R. D., The main tungsten area of Boulder County, Colo.: Colorado Geol. Survey First Rept., p. 75,1909 . 
but in several specimens of powdered ferberite examined I have not been able to separate it with a horseshoe magnet nor to find it by microscopic examination with reflected light in polished and etched specimens from the Western Star and Nugget claims. In the ore from the Eagle Rock mine, however, a small quantity of magnetic material which is probably magnetite was found.

Molybdenite.-George ${ }^{1}$ and Lindgren ${ }^{2}$ report, though 'Lindgren doubtfully, that molybdenite occurs with the ferberite in Boulder County. I have not seen this association. Molybdenite is a common associate of wolframite in Queensland ${ }^{3}$ and is also found with it in Saxony ${ }^{7}$ and England, ${ }^{5}$ but the association is rare in this country, though molybdenite occurs with wolframite and tourmaline on the Black Horse claims, 10 miles southeast of Daisy, Stevens County, Wash., and in small quantity with ferberite at Cave Creek, Ariz.

Opal.-Opal mixed with chalcedony and a little limonite forms a thin opaque yellowish-gray coating on ferberite crystals in the Black Hawk No. 1 vein, $1 \frac{1}{2}$ miles south of Nederland, and is probably a constituent of the siliceous coating on the ferberite from other mines.

Pyrite.-Pyrite is rare, except where the ferberite veins approach the gold and silver veins, though here and there a little may be found. At one place in the Conger mine a vein of pyrite 2 inches thick cut across the ferberite veins. Iron sulphide in quantities reaching 3.25 per cent ${ }^{6}$ is indicated by analyses of concentrates from a number of places, as noted under hematite.

Quartz.-Quartz occurs in all veins in comparatively small quantity. In most places it is so finely granular that it has a fracture like chalcedony. Very little of it shows crystal form.

Scheelite.-For discussion of the occurrence of scheelite see pages 11-12.

Sphalerite.-Sphalerite is noted by George (see Galena, p. 12), and Moses ${ }^{7}$ states that he found small yellow crystals upon ferberite specimens from the Boulder field.

Sylvanite.-As has been noted, sylvanite occurs with ferberite at Magnolia. George ${ }^{8}$ also notes this association in the vein exposed by the Wheelmen Tunnel in the lower part of the canyon of Boulder Creek and in a mine near Sunshine.

1 George, R. D., The main tungsten area of Boulder County, Colo.: Colorado Geol. Survey First Rept., p. $75,1809$.

2 Econ. Geology, vol. 2, p. 461, 1907.

Cameron, W. E., Wolfram and molybdenite mining in Queensland: Queensland Geol. Survey Rept. 188, 13 pp., 1904.

† Beck, R., Ưber ein kürzlich aufgeschlossenes Wolframerzgangfeld und einige andere neue Aufschlüsse in sächsischen Wolframerzgruben: Zeitschr. prakt. Geologle, vol. 15, pp. 38,40, 1907.

- Finlayson, A. M., The ore-bearing pegmatites of Carrock Fell and the genetic significance of tungsten ores: Geol. Mag., vol. 7, pp. 19-28, 1910.

- Hills, V. G., Tungsten mining and milling: Colorado Scl. Soc. Proc., vol. 9, p. 149, 1909.

7 Moses, A. J., The crystallization of luzonite and other crystallographic studies: Am. Jour. Sci., 4th ser., vol. 20, p. 282, 1905.

Op. cit., p. 76.

$35659^{\circ}-$ Bull. $583-14-2$ 


\section{SPECTROSCOPIC EXAMINATION OF THE FERBERITE.}

Scandium, ${ }^{1}$ columbium, tantalum, and other rare elements are found in some wolframites, and a specimen of ferberite from the Conger mine was sent with a specimen of scheelite to Prof. G. Eberhard, Potsdam, Germany, who kindly made a spectroscopic analysis of them. In a letter dated August 20, 1912, to Adolph Knopf, of the United States Geological Survey, Prof. Eberhard says:

The examination of the two minerals from Mr. Hess gave the following results:

The lines of $\mathrm{Ba}, \mathrm{Gl}, \mathrm{Pb}, \mathrm{Ga}, \mathrm{K}, \mathrm{Li}, \mathrm{Na}, \mathrm{Ni}, \mathrm{Ag}, \mathrm{Sn}, \mathrm{Bi}, \mathrm{Zn}$, and $\mathrm{Zr}$ are absent in both minerals. The lines of the following elements are present in ferberite:
Al, visible.
Mo, weak?.
$\mathrm{Ca}$, weak.
Cr, weak or absent.
Fe, strong.
$\mathrm{Cb}$, weak.
$\mathrm{Cu}$, weak.
$\mathrm{Mg}$, visible.
Mn, weak.
Sc, weak.
Si, strong.
$\mathrm{Sr}$, weak.
Ti, weak.
V, weak.
$\mathrm{W}$, strong.
Y, absent.

I have not sought for the elements not here listed. Lines marked "weak" indicate that the content of the element is small or very small. Lines marked "visible" indicate that the content of the element is fairly large. Lines marked "strong" indicate that the content of the element is large. The element whose presence I could not substantiate with absolute certainty I have marked with a question. The content of scandium is certainly smaller than 0.005 per cent and is therefore chemically not detectable.

Since this determination was made an article by H. S. Lukens ${ }^{2}$ has appeared, in which he describes the extraction of scandium from residues of Colorado tungsten ores that had been treated by the General Electric Co. at Schenectady, N. Y. Lukens found 0.05 per cent of scandium oxide in the residues. In reply to my inquiries the Primos Chemical Co., which had furnished the ores, wrote, under date of April 18, 1914:

- Regarding the scandium found in some of our ores, we have not yet located the point from which the ores come, but as a rule our residues contain no scandium. A great many tests are made right along. As we are getting ores from a great many points on our property, it is very difficult to tell from which particular openings they came. Most Boulder County ores contain no scandium. Have given samples right along to various universities, including the University of Pennsylvania, and though exhaustive tests have been made, not one of them has found any scandium.

Another letter, dated April 27, 1914, says:

As far as our records show, we shipped, with the probable exception of one small lot from Arizona, only Boulder County ores to the General Electric Co.

No tungstic ocher, muscovite, stibnite, bismuth minerals, fluorite, tourmaline, axinite, cassiterite, or topaz-minerals which in some places occur with wolframite deposits, particularly if closely connected with pegmatites-are known to have been found in the Boulder field.

1 Winter Herbert, Ueber Vorkommen und Reindarstellung des Scandiums: Inaugural-Dissertation, Friedrich-Wilhelms-Universität zu Berlin, pp. 22-23 et al., 1911. See also Mennicke, Hans, Die Metallurgie des Wolframs, pp. 111 et seq., 1911.

2 Scandium in American wolframite: Am. Chem. Soc. Jour., vol. 35, pp. 1470-1472, 1913. 


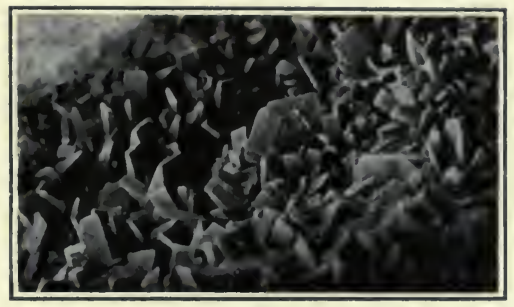

A. WEDGE-SHAPED FERBERITE CRYSTALS FROM THE LONE TREE MINE, NEDERLAND, COLO.

Fan-shaped intergrowth in right center. Coated with ammonium chloride. $\times 2$.

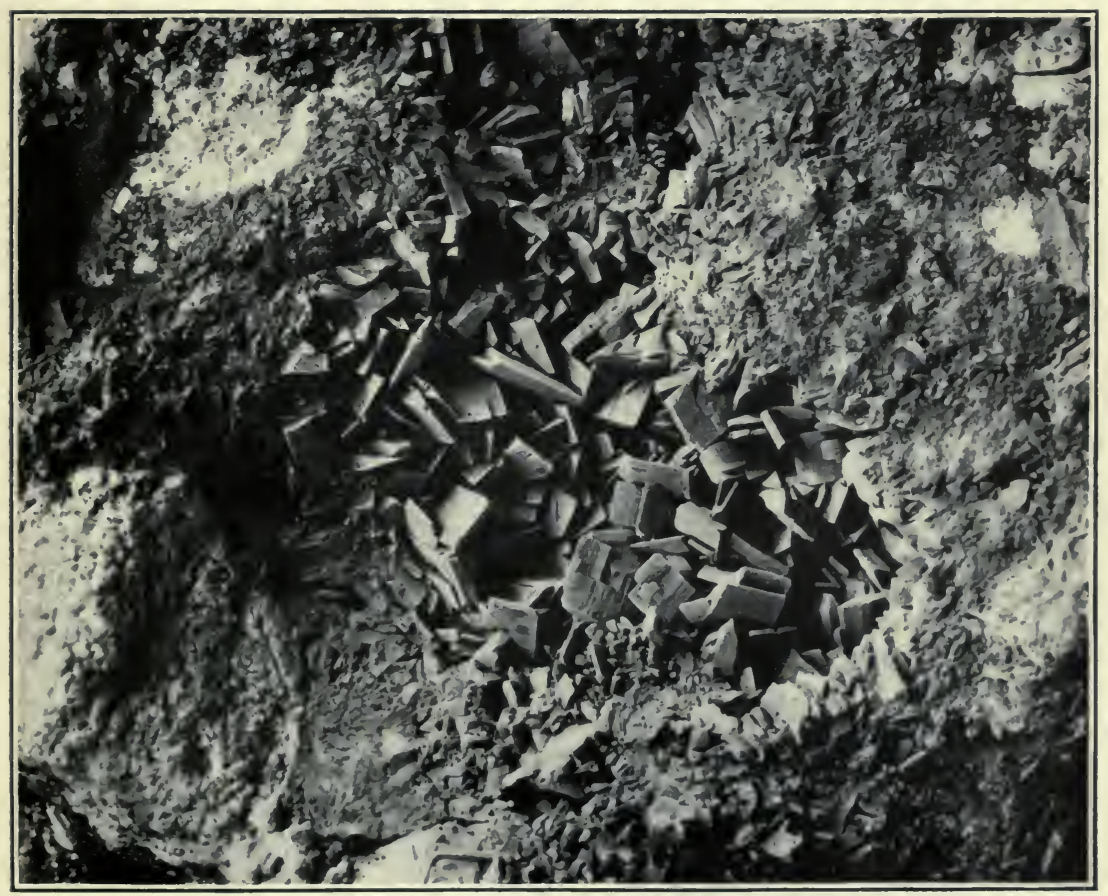

B. WEDGE-SHAPED FERBERITE CRYSTALS FROM THE HOOSIER MINE, NEDERLAND, COLO.

Fan-shaped intergrowth and twins in lower right center. Coated with ammonium chloride. $\times 2$. 


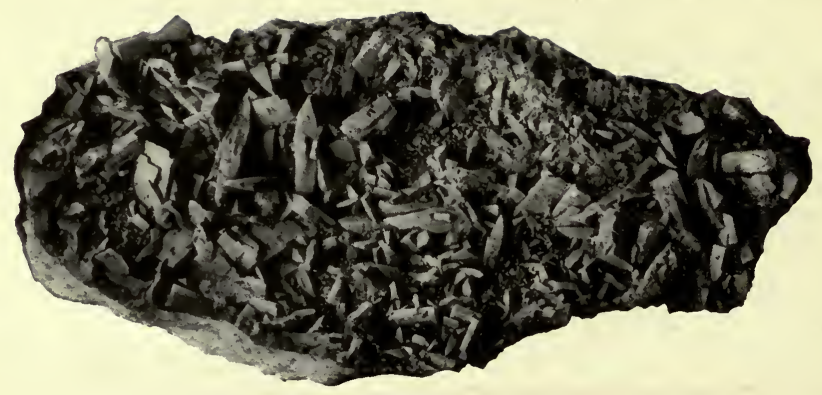

1. CRYStallized ferberite from the "CROW PATENT," NEDERLAND, COLO.

The crysta's are attached by the $c$ axis and show penetration twins and reentrant angles. Coated with ammonium chloride. Natural size.

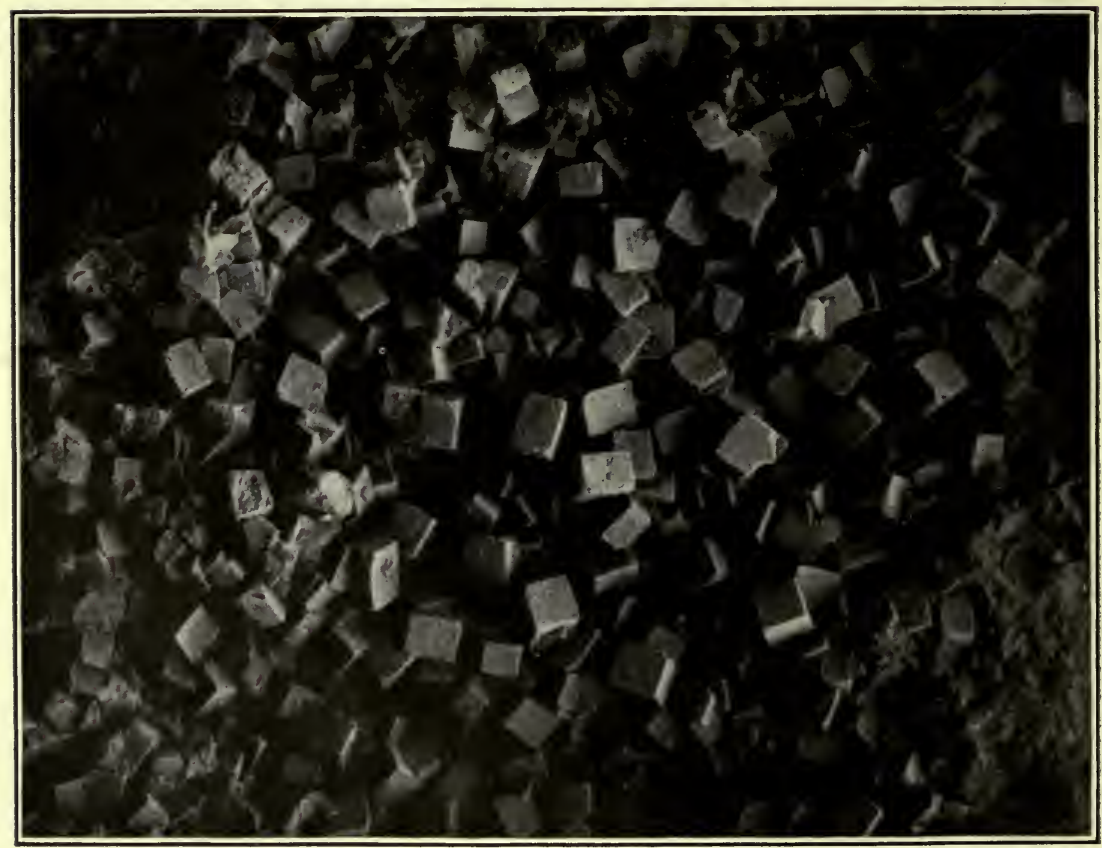

B. CRYSTALLIZED FERBERITE FROM THE GEORGIA A. MINE, NEDERLAND, COLO.

Coated with ammonium chloride, $\times 10$. 


\section{CRYSTALLIZED FERBERITE.}

As has been stated, the ferberite commonly occurs in definite crystal forms and the beauty of the crystals is unique. However, although crystals are common, good specimens suitable for display in museums are very rare, for most of the crystals are so small that they appear insignificant; they are very fragile and are easily broken in mining; and in many places they are coated with mixtures of chalcedony, opal, and hydrous iron oxides in varying proportions. This coating may be removed from some specimens without serious injury by treatment with hydrofluoric and sulphuric acids, but crystals so treated show uneven surfaces when an attempt is mado to measure them with a goniometer.

Probably a wedge shape is the commonest form of the crystals. This form occurs in many of the mines. One of the best specimens seen is from the Hoosier mine, between 1 and 2 miles northeast of Nederland (Pl. VII, $B$ ). The wedge shapes are formed by the terminations at the ends of the $b$ axis and most of the crystals are attached at one end of this axis. Some crystals are intergrown in such a way as to produce a fan shape (Pl. VII, $A$ and $B$ ). In a few specimens crystals attached by one end of the $c$ axis are prominent, in which case the termination at each end of the $b$ axis is shown. Some of the crystals show penetration twins, extending through $c\{001\}$. Around the penetrating crystal in two or three occurrences there seem to be reentrant angles in the penetrated members (Pl. VIII, $A$ ). The specimen illustrated came from a tract of land known as the Crow patent, near Nederland.

In a specimen from the Georgia $\mathrm{A}$. claim the crystals are almost cubic and about one one-hundredth inch (0.25 millimeter) across. Plate VIII, $B$, represents the specimen magnified 10 diameters.

Another form of crystal is found on the Nugget and the Winnebago claims, near Rollinsville, Gilpin County. In this form the crystal presents a face (b) which is a long, narrow rhomb, with a length of about three-eighths inch (9.4 millimeters) and a width one-tenth to one-fifth as much. Typical specimens are shown in Plates IX and $\mathrm{X}$. In some specimens the rhomb has sides much more nearly of equal length. (See Pl. XI.) Plate XII shows a very fine specimen with peculiar, irregular faces. The crystal forms are described at length by W. T. Schaller in the latter part of this bulletin.

\section{COMPOSITION OF FERBERITE AND OTHER MEMBERS OF THE WOLFRAMITE SERIES.}

The original ferberite was found in the Sierra Almagrera, in southern Spain, and is stated by Liebe ${ }^{1}$ to have been named by Breithaupt for R. Ferber, of Gera. Liebe made an analysis of the mineral. (See analysis No. 79, pp. 32-33.) 
The next year Rammelsberg ${ }^{1}$ published an article on ferberite with an analysis of his own material (see analysis No. 82) from the same locality as that described by Liebe. He quotes Liebe's analysis and shows that the iron oxide and tungsten trioxide are not in a simple ratio and that there is an excess of iron oxide. Neither mineral was pure, and the analyses are not very satisfactory, so that calculation of iron in excess is uncertain, for it was probably present as an impurity and not as a part of the mineral. Liebe deducted 1.39 per cent limonite from his analysis.

It seems certain that the calcium present should be calculated as scheelite, for scheelite almost always if not invariably accompanies other tungsten materials. It is not visible in all specimens to the unaided eye, but microscopic examination generally shows it as interstitial, inclosed in the wolframite crystals, filling vugs, or occurring separately in the deposit. (See Pl. V, p. 14, and Pl. XIII, $A$ and $B$, p. 30.)

Some magnesium was found, but this element is not known to be a constituent of tungsten minerals, although A. M. Finlayson ${ }^{2}$ gives an analysis of scheelite from Donaldsons, New Zealand, containing 0.2 per cent $\mathrm{MgO}$, which he considers to be combined with $\mathrm{WO}_{3}$, taking the place of $\mathrm{CaO}$, and Damour ${ }^{3}$ considered that both calcium and magnesium might take the place of iron or manganese in wolframite. That magnesium takes the place of either calcium or iron in tungsten minerals seems to me altogether unlikely. If it did so, some pure tungsten mineral-that is, some mineral which could be shown by microscopic or other examination not to contain particles of other substances-would probably be found in which the magnesium would form a considerable part of the mineral, just as do those elements known to form natural tungstates-namely, calcium, copper, iron, lead, and manganese. Therefore, in recalculating these and other analyses on pages 24-35, neither magnesium nor calcium has been considered as belonging to the wolframite.

To obtain a basis for differentiating ferberite from the remainder of the wolframite group all the analyses of wolframites (by which term is meant all members of the iron-manganese tungstate series) available to the author have been collected for comparison. More than 300 analyses were examined, but of these some represented ores rather than minerals; in many the $\mathrm{WO}_{3}$ had been determined by difference, which amounts to little more than a guess; in some the figures gave evidence that either the analytical work was bad or that the material was so impure that no proper comparison of the results would be possible. Where several analyses of the same material were obtained, only one has been tabulated.

\footnotetext{
1 Rammelsberg, C. F., Über die chemische Zusammensetsung des Ferberite: K. Akad. Wiss. Berlin Monatsber., Jahre 1864, pp. 175-176, 1865.

2 Finlayson, A. M., The scheelite of Otago: New Zealand Inst. Trans. and Proc., vol. 40, p. 112, 1908.

${ }^{3}$ Damour, A., Sur le wolfram tantalifère du département de la Haute-Vienne: Soc. géol. France Bull., 2d ser., vol. 5, p. 108, 1848.
} 


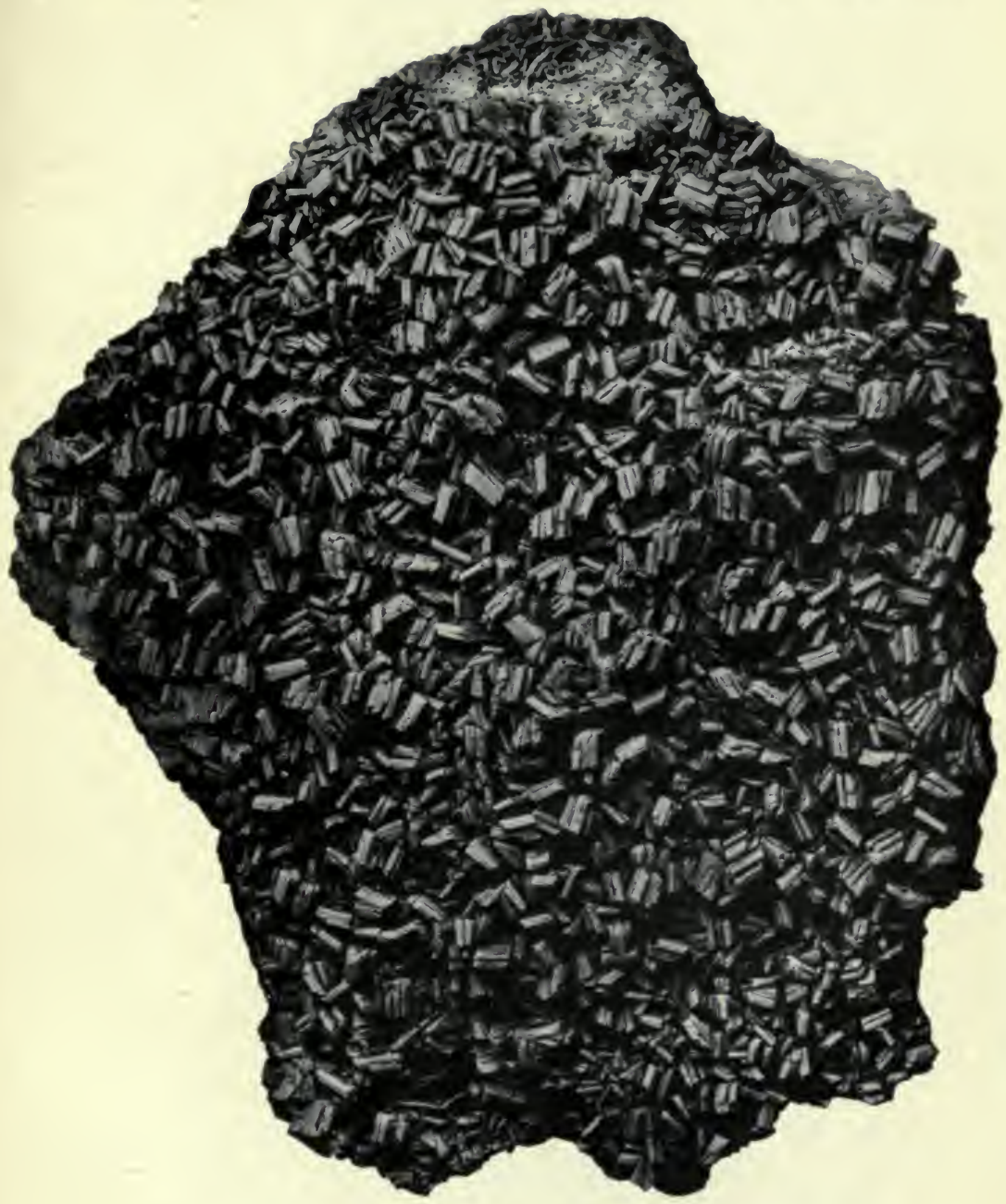

CRYSTALLIZED FERBERITE WITH ELONGATED RHOMBIC CRYSTAL FACES.

From the Nugget mine, Gilpin County, Colo. Coated with ammonium chloride. Natural size. 


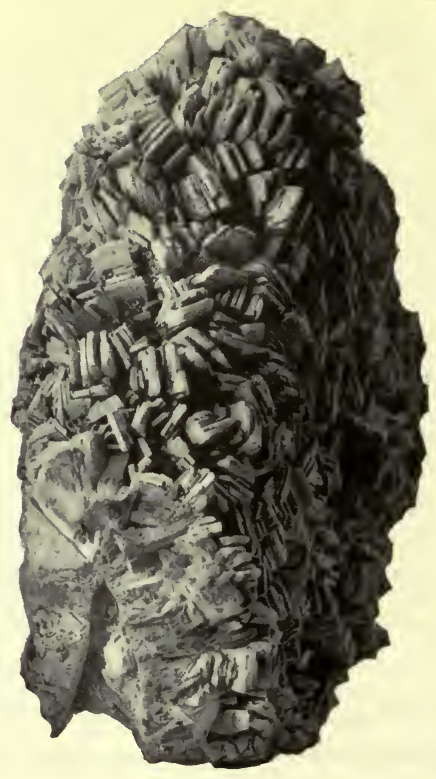

$A$.

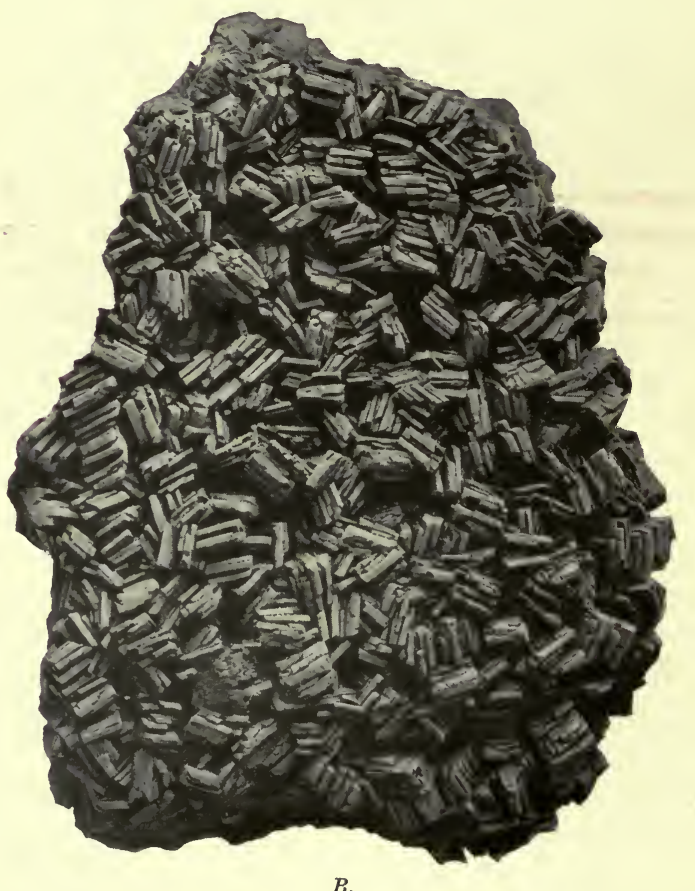

$B$.

CRYSTALLIZED FERBERITE WITH ELONGATED RHOMBIC CRYSTAL FACES.

From the Nugget mine, Gılpin County, Colo. Coated with ammonium chloride. Natural size. $A$, Edge view. $B$, Side view. 
The analyses have all been recalculated in order to bring them to a common basis on which they can properly be compared.

To do this it has been assumed that the theoretically pure members of the wolframite series contain only the hübnerite molecule, $\mathrm{MnWO}_{4}$; the ferberite molecule, $\mathrm{FeWO}_{4}$; or a combination of the two molecules. All analyses have been reduced to these simple forms.

As scheelite, the calcium tungstate, $\mathrm{CaWO}_{4}$, almost universally accompanies the wolframites, the lime indicated in the analyses has been considered to be a component of scheelite unless data given with the analysis showed it to belong to some other mineral, such as fluorite. As the $\mathrm{CaO}$ is an impurity, it has therefore ordinarily been satisfied with $\mathrm{WO}_{3}$ and then discarded with all items other than $\mathrm{FeO}$, $\mathrm{MnO}$, and $\mathrm{WO}_{3}$. Of course, this scheme probably leads to error in certain of the analyses, as the lime in some may be derived from other sources than scheelite, but these sources can not all be known, and as a general rule the process just described seems warranted. As applied to the Boulder field in particular there can be little objection, as lime-bearing minerals other than scheelite are uncommon. Calciferous feldspars seem to occur in very few places, calcite is rare, and no other lime minerals have been noted in the veins.

The analyses have been arranged in a series of decreasing $\mathrm{MnWO}_{4}$ and increasing $\mathrm{FeWO}_{4}$ content, so that the series begins with the hübnerites and ends with the ferberites. This has determined the order of calculation, for the natural procedure has been to satisfy first the $\mathrm{MnO}$ with $\mathrm{WO}_{3}$ and then to combine the remaining $\mathrm{WO}_{3}$ with so much of the $\mathrm{FeO}$ as it would take up. Arbitrary or casual reasons are not the only bases for this mode of calculation, however, for manganese is much less common as an impurity in wolframites than is iron.

The quantity of $\mathrm{MnWO}_{4}$ and $\mathrm{FeWO}_{4}$ obtained as a result of the operations has then been treated as the theoretically pure wolframite present in the substance analyzed, all other substances present being considered as impurities. From the theoretical wolframite as a basis have been computed the percentages of $\mathrm{WO}_{3}, \mathrm{FeO}, \mathrm{MnO}, \mathrm{FeWO}_{4}$, and $\mathrm{MnWO}_{4}$ of which it is composed.

In making the calculations the following atomic values and molecular ratios have been used:

Atomic weight.

Calcium ................... 40

Iron......................... 56

Manganese.................. 55

Oxygen ..................... 16

Tungsten.................... 184

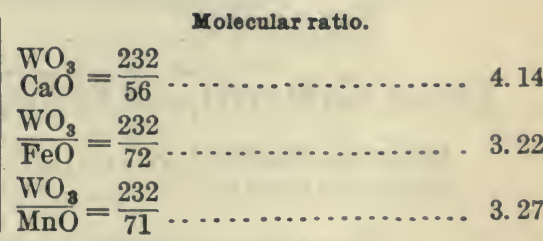

The values of the atomic weights are used only to the nearest integer and the ratios to the second decimal. These values are as 
exact as are warranted by the errors due to the uncertainty of the constituent minerals of the analyzed material and to the faults of analysis.

As an example of the process of calculation, analysis 37 may be taken:

Analysis of wolframite from Hill City, S. Dak.

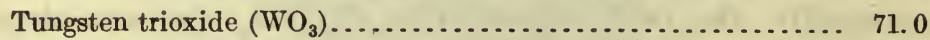

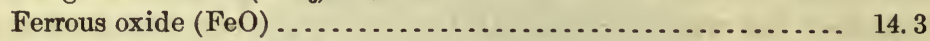

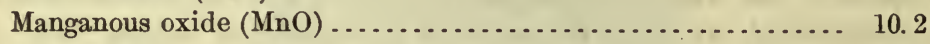

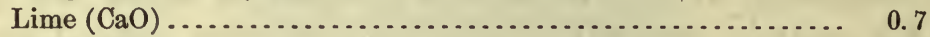

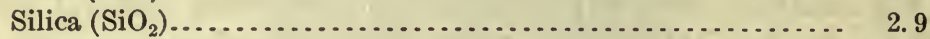

Magnesia $(\mathrm{MgO})$..................................... None.

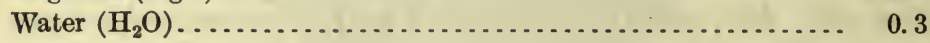

$$
\begin{aligned}
& \begin{array}{c}
\mathrm{CaO} \\
0.7 \times 4.14=2.9
\end{array} \\
& \stackrel{\mathrm{CaO}}{0.7}+2.9=3.6 \\
& \begin{array}{r}
\mathrm{MnO} \\
10.2 \\
\frac{\mathrm{WO}_{3}}{\mathrm{MnO}}
\end{array}=\begin{array}{r}
\mathrm{WO}_{3} \\
\hline .27
\end{array} \\
& \mathrm{MnO} \quad \mathrm{WO}_{3} \quad \mathrm{MnWO}_{4} \\
& 10.2+33.4=43.6
\end{aligned}
$$

$\mathrm{WO}_{3}$ required to satisfy the $\mathrm{CaO}$ and $\mathrm{MnO} \ldots \ldots \ldots \ldots \ldots \ldots \ldots . . . \ldots \ldots$

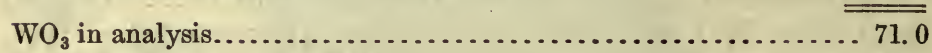

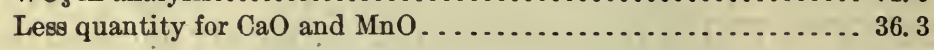

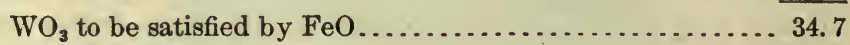

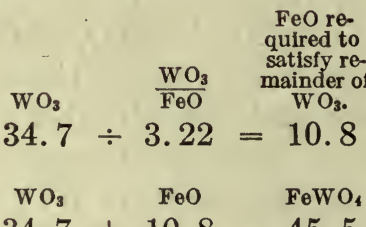

$$
\begin{aligned}
& 34.7+10.8=45.5
\end{aligned}
$$

$\mathrm{FeO}$ in analysis............................................ 3

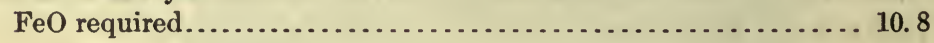

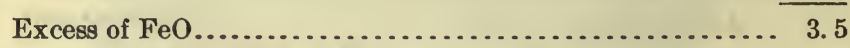

Adding the $\mathrm{MnWO}_{4}$ and $\mathrm{FeWO}_{4}$,

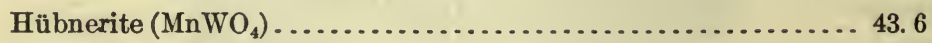

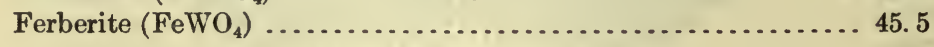

Theoretical wolframite in the material analyzed......... 89.1 

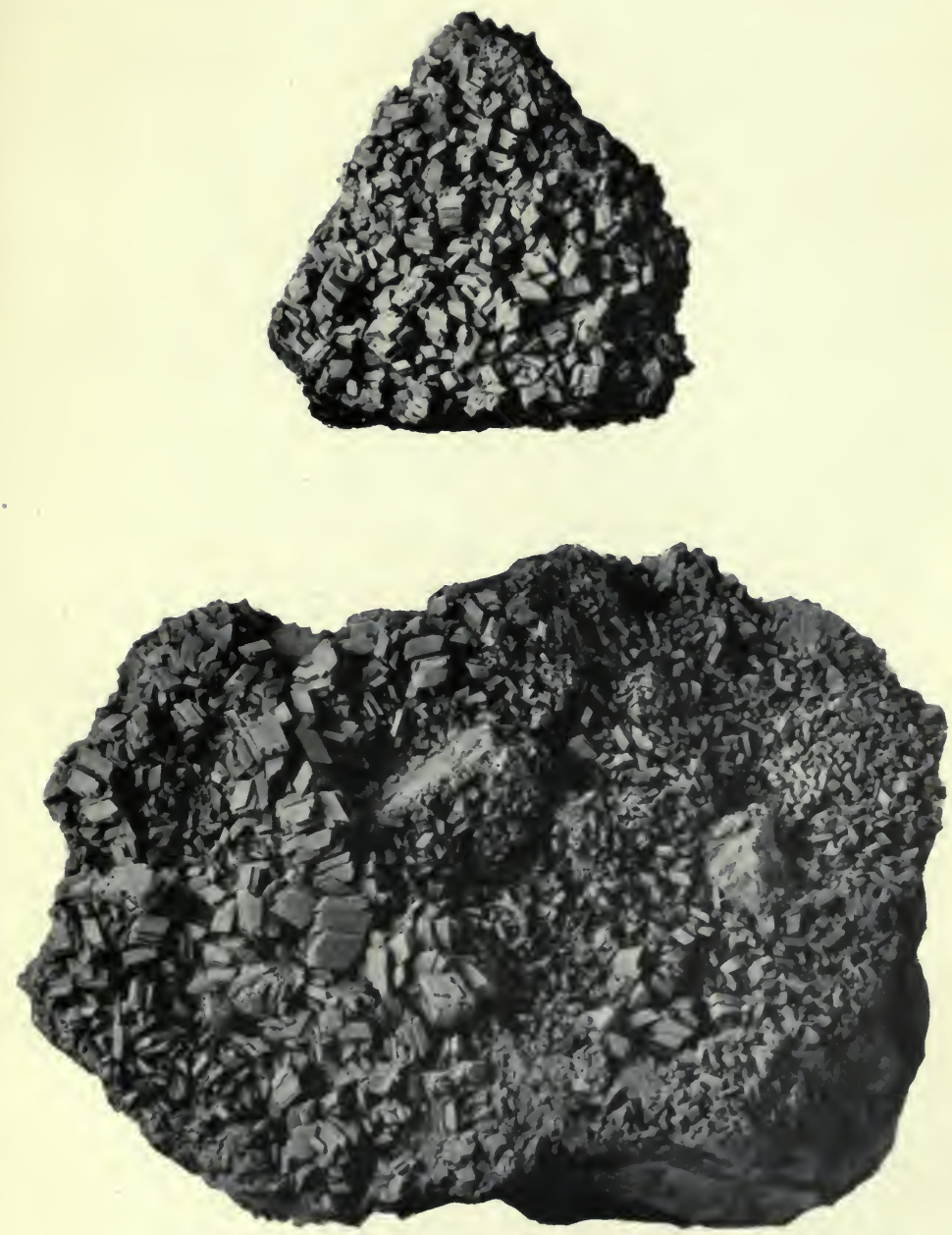

FERBERITE WITH RHOMBIC CRYSTAL FACES.

From the Nugget mine, Gilpin County, Colo. Coated with ammonium chloride. Natural size. 


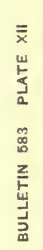

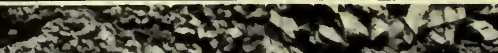

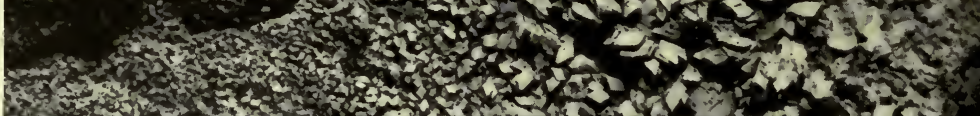

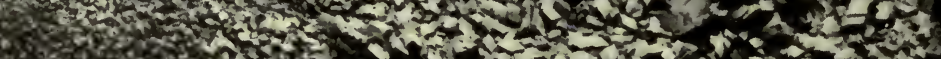

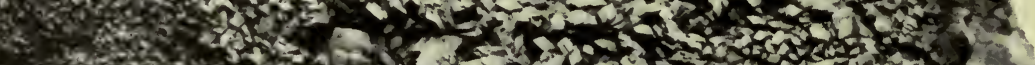

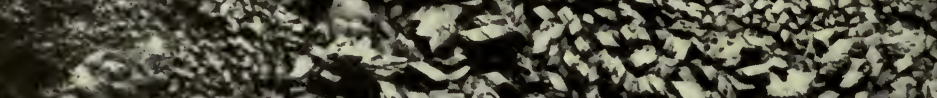

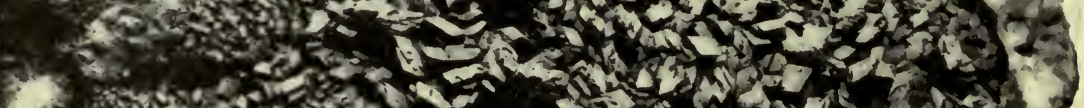

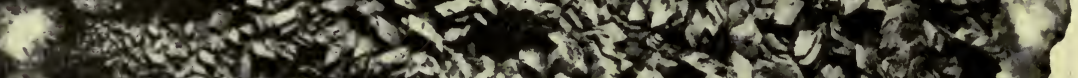

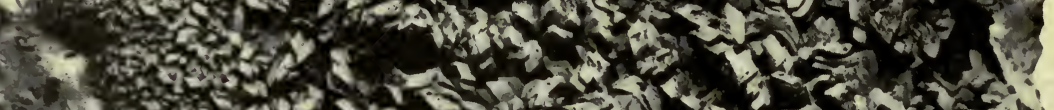

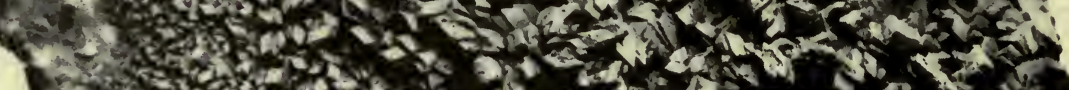

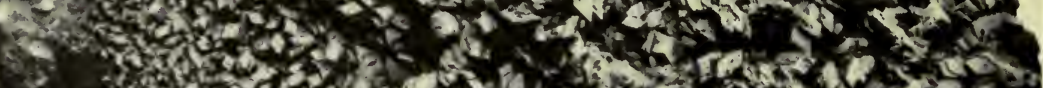

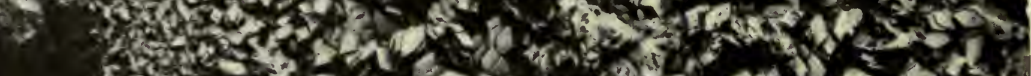

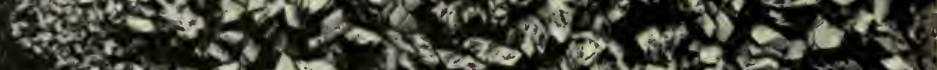

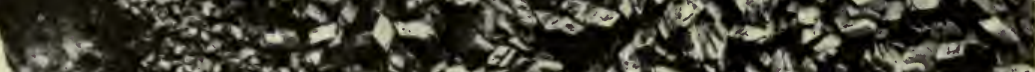

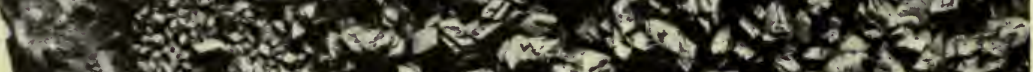

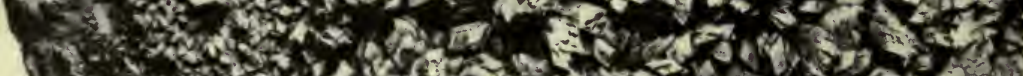

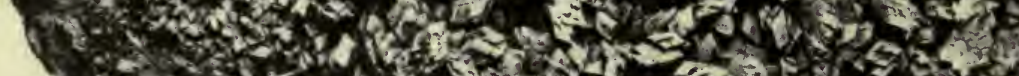

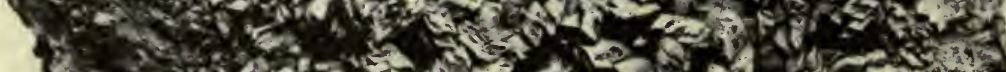

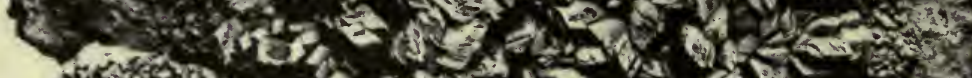

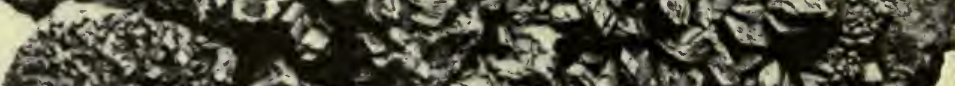

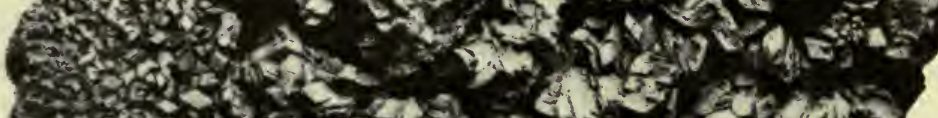

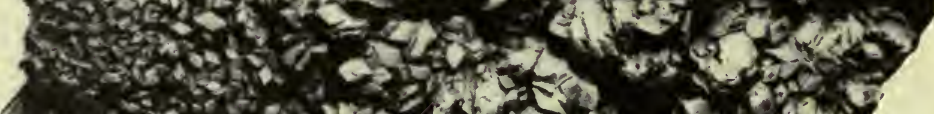

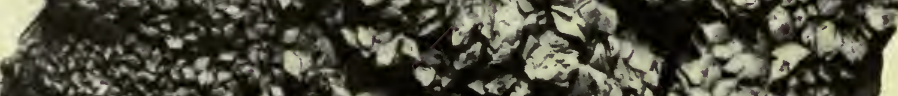

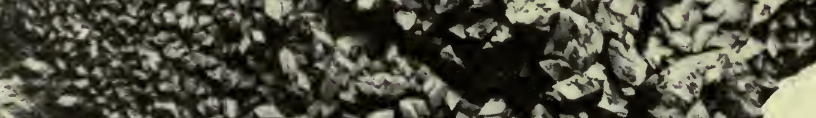
2.

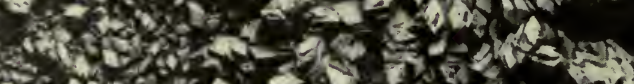

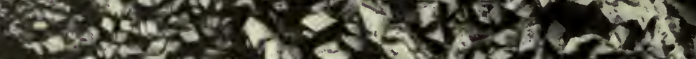

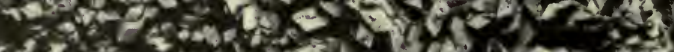

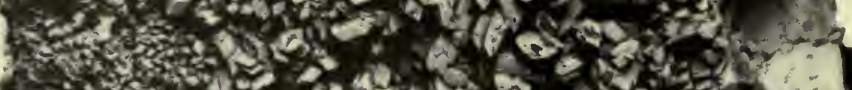

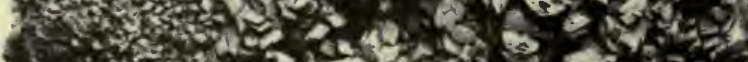

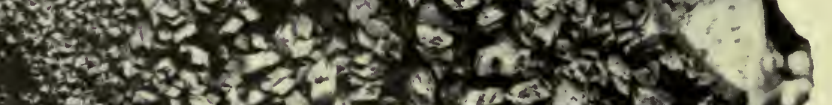

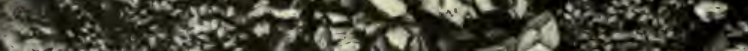

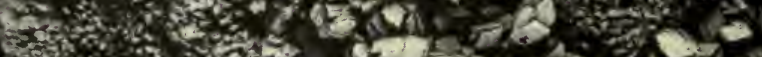


COMPOSITION OF FERBERITE AND OTHER MEMBERS OF SERIES. 23

Recalculating to percentages of the theoretical wolframite and then breaking up into oxides,

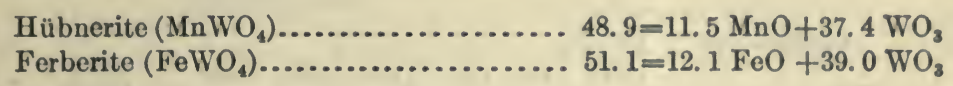

Total $\mathrm{WO}_{3}$ in theoretical wolframite

$\overline{76.4}$

The presence of water $(0.3)$ in the analysis probably indicates that a part of the apparent excess of $\mathrm{FeO}(3.5)$ is limonite. The 0.3 per cent of water will combine with 1.6 per cent of $\mathrm{FeO}$ to form 2.1 per cent of limonite, considered as $2 \mathrm{Fe}_{2} \mathrm{O}_{3} \cdot 3 \mathrm{H}_{2} \mathrm{O}$. This still leaves an excess of 1.9 per cent $\mathrm{FeO}$.

Summarizing, the calculation shows the wolframite to have a composition of-

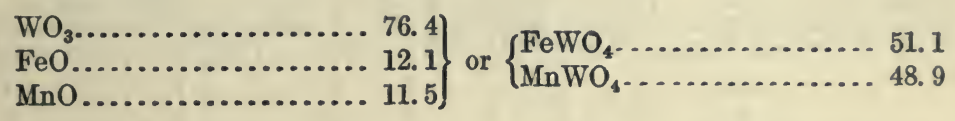

With which is associated in the mass scheelite, $\mathrm{CaWO}_{4}, 3.6$; excess FeO, 1.9; limonite, 2.1. 
Analyses of minerals of

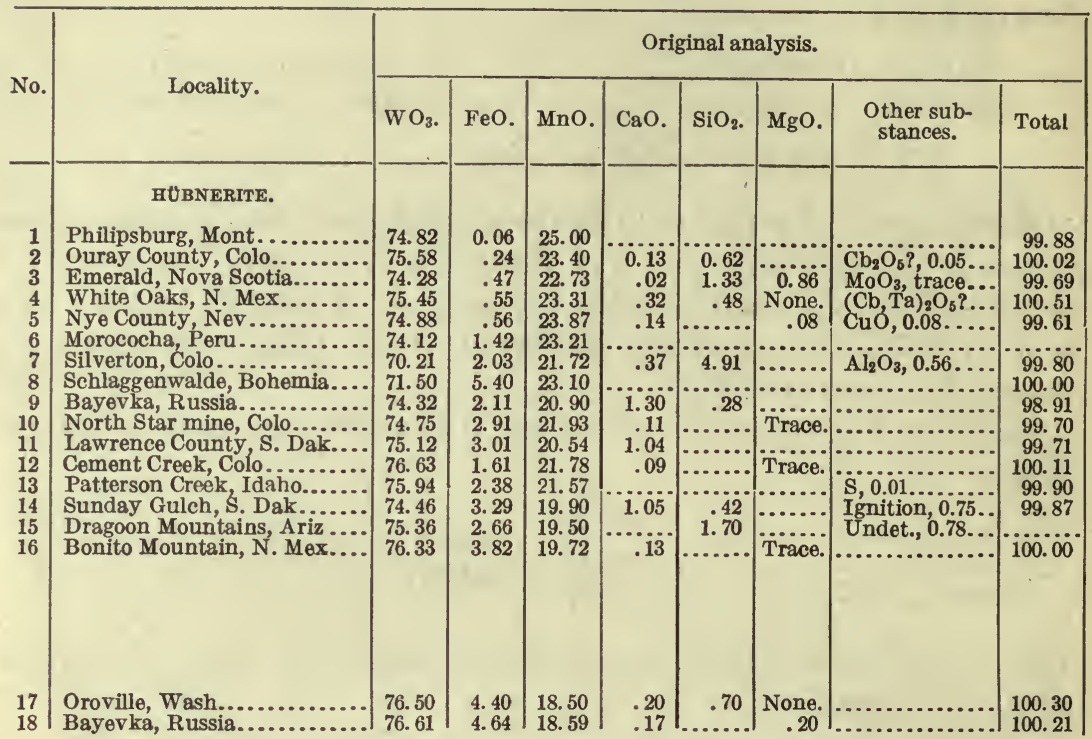

1. Hübnerite from Philipsburg, Mont. Analysis by A. H. Low quoted from Richard Pearce by Hillebrand, W. F., Miscellaneous mineral notes; Contributions to the mineralogy of the Rocky Mountains: U. S. Geol. Survey Bull. 20, p. 96, 1885.

2. Hübnerite from the Royal Albert vein, Uncompahgre district, Ouray County, Colo. Hillebrand, W. F., Miscellaneous mineral notes; Contributions to the mineralogy of the Rocky Mountains: U. S. Geol. Survey Bull. 20, p. 96, 1885.

3. Hübnerite from Emerald, Nova Scotia. Johnston, R. A. A., Hübnerite: Canada Geol. Survey Ann. Rept., new ser., vol. 11, p. 10R, 1898.

4. Hübnerite from the South Homestake mine, White Oaks, N. Mex. Analysis by J. G. Dinwiddie. Besides the items given the analysis showed $\mathrm{H}_{2} \mathrm{O}$ at $110^{\circ} \mathrm{C}$., none; $\mathrm{H}_{2} \mathrm{O}$ above $110^{\circ} \mathrm{C}, 0^{0.40}$. This hübnerite is to the unaided eye as black as the ferberite of the Boulder field, but in thin section it is translucent brown and olivegreen. The streak is olive-green. Microscopic examination showed no scheelite but much fluorite, so that the calcium has been considered as derived from that mineral. See also analysis 16.

5. Hübnerite from Riotte's original locality, Ellsworth, Mammoth district, Nye County, Nev. Genth, F. A., Contributions to mineralogy, No. 52; with crystallographic notes by S. L. Penfield: Am. Jour. Sci., 3d ser., vol. 43, p. 187, 1892.

6. Hübnerite from Morococha, Peru. Analysis by Pflücker quoted by Domeyko, Ignacio, Mineralojía, vol. 2, p. 92, 1897.

7. Hübnerite from the Natalie mine, Silverton, Colo. Ekeley, J. B., Some Colorado tungsten ores: Min. World, vol. 30, p. 280, 1909.

8. Hübnerite from Schlaggenwalde, Bohemia. Rammelsberg, C. F., Handbuch der Mineralchemie, p. 309, 1860. Fine red-brown needles, with fluorspar and apatite.

9. Average of two analyses of hübnerite from Bayevka, Ural Mountains, Russia. Koulibin, Von N. v., Manganhaltiger Wolfram aus der Grube Bajewsk am Ural: Russ.-k. mineral. Gesell. St. Petersburg Verh., vol. 3, 2d ser., p. 3, 1868.

10. Hübnerite from the North Star mine, Silverton, Colo. Genth, F. A., Contributions to mineralogy, No. 52; with crystallographic notes by S. L. Penfield: Am. Jour. Sci., 3d ser., vol. 43, p. 186, 1892. 
the wolframite series.

\begin{tabular}{|c|c|c|c|c|c|c|c|c|c|}
\hline \multirow{2}{*}{ No. } & \multicolumn{8}{|c|}{ Recalculated analysis. } & \multirow{2}{*}{$\begin{array}{l}\text { Specific } \\
\text { gravity. }\end{array}$} \\
\hline & $\mathrm{WO}_{8}$ & $\mathrm{FeO}$. & MnO. & FeWO4. & $\mathrm{MnWO}_{4}$ & $\begin{array}{c}\text { Excess } \\
\text { FoO. }\end{array}$ & $\begin{array}{l}\text { Excoss } \\
\text { MnO. }\end{array}$ & $\mathrm{CsWO}_{4}$. & \\
\hline 1 & 76.6 & & 23.4 & & 100.0 & & 2.1 & & \\
\hline 2 & 76.6 & ... & 23.4 & & 100.0 & .2 & .5 & 0.7 & 7.177 \\
\hline 3 & $\begin{array}{l}76.6 \\
76.6\end{array}$ & $\ldots$ & 23.4 & $\cdots$ & 100.0 & .5 & $\dddot{2}$ & 1 & \\
\hline $\begin{array}{l}4 \\
5\end{array}$ & $\begin{array}{l}76.6 \\
76.6\end{array}$ & .. & $\begin{array}{l}23.4 \\
23.4\end{array}$ & & $\begin{array}{l}100.0 \\
100.0\end{array}$ & .6 & 1.2 & .7 & \\
\hline 6 & 76.6 & & 23.4 & & 100.0 & 1.4 & .5 & & \\
\hline 7 & 76.6 & & 23.4 & .... & 100. & 2.0 & .7 & 1.9 & \\
\hline 8 & 76.6 & & 23.4 & $\because 7$ & 100.0 & 5.4 & 1.2 & & 6.45 \\
\hline 9 & 76.6 & 0.2 & 23.2 & 0.8 & 99.2 & 1.9 & & 6.7 & 7.357 \\
\hline 10 & 76.6 & .8 & 22.6 & 3.2 & 96.8 & 2.3 & $\ldots . .$. & .6 & 6.713 \\
\hline 11 & 76.6 & 1.4 & 22.0 & 6.0 & 94.0 & 1.2 & ..... & 5.4 & \\
\hline 12 & 76.6 & 1.6 & 21.8 & 6.7 & 93.3 & .1 & 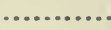 & .5 & 6.891 \\
\hline 13 & 76.6 & 1.6 & 21.8 & 6.9 & 93.1 & .8 & $\cdots$ & & \\
\hline 14 & 76.6 & 1.7 & 21.7 & 7.2 & 92.8 & 1.7 & ..... & 4.4 & .......... \\
\hline $\begin{array}{l}15 \\
16\end{array}$ & $\begin{array}{l}76.5 \\
76.6\end{array}$ & $\begin{array}{l}2.8 \\
3.5\end{array}$ & $\begin{array}{l}20.7 \\
19.9\end{array}$ & $\begin{array}{l}11.6 \\
14.9\end{array}$ & $\begin{array}{l}88.4 \\
85.1\end{array}$ & .1 & ........ & $\begin{array}{r}4.1 \\
.7\end{array}$ & $\dddot{7.163}$ \\
\hline & & & - & & & & $\begin{array}{l}\text { Excess } \\
\mathrm{WO}_{3} .\end{array}$ & & \\
\hline $\begin{array}{l}17 \\
18\end{array}$ & $\begin{array}{l}76.6 \\
76.5\end{array}$ & 4.5 & $\begin{array}{l}18.9 \\
18.8\end{array}$ & 19.1 & 80.9 & & 1.7 & 1.0 & $\begin{array}{l}7.20 \\
7.267\end{array}$ \\
\hline & 76.5 & & $18.8 \mid$ & 19.8 & 80.2 & & & & \\
\hline
\end{tabular}

11. Hübnerite from the Comstock mine, Lawrence County, S. Dak. Headden, W. P., Mineralogical notes: Colorado Sci. Soc. Proc., vol. 8, p. 175, 1906. "A black mineral fairly well crystallized."

12. Hübnerite from Cement Creek, Silverton, Colo. Genth, F. A., Contributions to mineralogy, No. 52; with crystallographic notes by S. L. Penfield: Am. Jour. Sci., 3d ser., vol. 43, p. 186, 1892.

13. Hübnerite from the Idaho Tungsten Co.'s property in the Blue Wing district, on Patterson Creek, Lemhi County, Idaho. An unpublished analysis by J. E. Talmadge, communicated by J. G. Lind. It seems improbable that from these deposits a specimen could be selected, the analysis of which would show neither $\mathrm{SiO}_{2}$ nor $\mathrm{CaO}$, but this is of course surmise. In the analysis given, were the ordinary error of high $\mathrm{MnO}$ made, it might account for the good summation, were other elements undetermined. On the other hand, manganese oxides occur in the vein in some quantity (see Umpleby, J. B., Geology and ore deposits of Lemhi County, Idaho: U. S. Geol. Survey Bull. 528, pp. 3, etc., 1913), and it may well be that they are present in interstices of the hübnerite, part of which is so dark as to suggest the inclusion of either manganese or iron oxides.

14. Hübnerite from Sunday Gulch, near Hill City, S. Dak. Headden, W. P., Mineralogical notes: Colorado Sci. Soc. Proc., vol. 8, p. 176, 1906. "Granular, almost entirely free from admixed gangue". (p. 175).

15. Hübnerite from Dragoon Mountains, Ariz. Guild, F. N., The mineralogy of Arizona, p. 92, 1910.

16. Hübnerite from Bonito Mountain, near White Oaks, N. Mex. Genth, F. A., Contributions to mineralogy, No. 52; with crystallographic notes by S. L. Penfield: Am. Jour. Sci., 3d ser., vol. 43, p. 187, 1892.

17. Hübnerite from Oroville, Wash. R. C. Wells, of the U. S. Geol. Survey, analyst. $\mathrm{SiO}_{2}$ includes any other insolubles. $\mathrm{Ta}, \mathrm{Cb}, \mathrm{Sn}, \mathrm{Mo}$, and rare earths are not present in appreciable quantities.

18. Average of two analyses of hübnerite from Bayevka, Ural Mountains. Beck, W., and Teich, N., Ueber Wolfram und Scheelit aus Fundörten Russlands: Russ.-k. mineral. Gesell. St. Petersburg Verh., 2d ser., vol. 4, pp. 315-316, 1869. 
Analyses of minerals of

\begin{tabular}{|c|c|c|c|c|c|c|c|c|c|}
\hline \multirow{2}{*}{ No. } & \multirow{2}{*}{ Locality. } & \multicolumn{8}{|c|}{ Original analysis. } \\
\hline & & $\mathrm{WO}_{3}$ & $\mathrm{FeO}$. & Mno. & $\mathrm{CaO}$ & $\mathrm{SiO}_{2}$ & $\mathrm{MgO}$ & $\begin{array}{l}\text { Other sub- } \\
\text { stances. }\end{array}$ & Total. \\
\hline & WOLFRAMTTE. & & & & & & & & \\
\hline $\begin{array}{l}19 \\
20\end{array}$ & $\begin{array}{l}\text { Whetstone Mountains, Ariz.. } \\
\text { Zinnwald, Germany......... }\end{array}$ & $\begin{array}{l}74.20 \\
76.20\end{array}$ & $\begin{array}{l}5.15 \\
5.60\end{array}$ & $\begin{array}{l}18.09 \\
17.94\end{array}$ & & 1.95 & & & $\begin{array}{l}99.39 \\
99.74\end{array}$ \\
\hline 21 & Zinnwald, Bohemia............ & 76.50 & 10.30 & 12.20 & $1.10^{\circ}$ & & Trace. & $\mathrm{SnO}_{2}$, trace. & 100.10 \\
\hline 22 & Zinnwald (Germany?) & 73.60 & 11.20 & 15.75 & & & & & 100.55 \\
\hline 23 & Lake Couchiching, Ontario.. & 73.45 & 9.05 & 15.35 & & .20 & & $\mathrm{Cb}_{2} \mathrm{O}_{5} ?, 1.95$ & 100.00 \\
\hline 24 & Zinnwald, Germany.. & 75.62 & 9.55 & 14.85 & & & & & 100.02 \\
\hline 25 & Altenberg, Germany. & 75.44 & 9.64 & 14.90 & & & & & 99.98 \\
\hline 26 & Zinnwald, Germany. & 76.01 & 9.81 & 13.90 & 1. 19 & & & & 100.91 \\
\hline 27 & Freiberg, Germany ............ & 75.84 & 9. 20 & 14.56 & & & & & 99.60 \\
\hline 28 & Schlaggenwalde, Bohemia... & 75.68 & 9.56 & 14.30 & & & & & 99.54 \\
\hline 29 & Zinnwald (Germany?). & 75.99 & 9.62 & 13. 96 & .48 & & & & 100.05 \\
\hline 30 & Zinnwald, Germany ... & 76.34 & 9.61 & 14.21 & & & & & 100.16 \\
\hline 31 & .....do............... & 75.62 & 8.73 & 12.17 & 2.27 & . & & $\left\{\mathrm{TiO}_{2} 1.89\right.$ & 100.99 \\
\hline 32 & Tenasserim, Burma.... & 72.80 & 11.44 & 12.08 & 1.18 & 2.36 & & Loss, 0.14 . & 100.00 \\
\hline 33 & Cornwall, Engl & 74.84 & & 12.55 & .80 & .30 & 12 & $(\mathrm{Ta}, \mathrm{Cb}$ & 100.38 \\
\hline 34 & Lost River, Alaska.. & 74.90 & 10.60 & 12. 80 & .30 & :90 & Trace? & $\mathrm{PbO}$, trace? & 100.10 \\
\hline 35 & Vilate, France... & 73.93 & 12.97 & 11.60 & & & & $\mathrm{Ta}_{2} \mathrm{O}_{6}, 1.03 \ldots$ & 99.53 \\
\hline 36 & Sudzukoya, Japan... & 71.90 & 15. 29 & 10.64 & & 1.02 & & Undet., 1.15. & \\
\hline $\begin{array}{l}37 \\
38\end{array}$ & Hill City, s. Dak........ & 71.00 & 14.30 & 10.20 & .70 & 2.90 & None. & $\mathrm{H}_{2} \mathrm{O}, 0.30 \ldots$ & 99. 40 \\
\hline & & & & & & & & & \\
\hline
\end{tabular}

19. Wolframite from the Whetstone Mountains, 12 miles south of Benson, Ariz. Analysis by J. M. Ruthrauff quoted by Guild, F. N., The mineralogy of Arizona, p. $94,1910$.

20. Wolframite from Zinnwald, Germany. Bernoulli, F. A., Ueber Wolfram und einige seiner Verbindungen: Poggendorf's Annalen, 4th ser., vol. 21, p. 604, 1860.

21. Wolframite from Zinnwald, Bohemia. Helmhacker, R., Wolfram ore: Eng. and Min. Jour., vol. 62, p. 154, 1896.

22. Wolframite from Zinnwald (Germany?). Richardson, T., Analysis of wolfram: Thomson's Records of general science, vol. 1, p. 451, 1835.

23. Wolframite from Lake Couchiching, Ontario. Hunt, T. S., Analysis of Canadian wolfram: Canadian Jour., new ser., vol. 5, p. 303, 1860.

24. Wolframite from Zinnwald, Germany. Kerndt, T., Ueber die Krystallform und chemische Zusammensetzung der natürlichen und künstlichen Verbindungen des Wolframmetalles: Jour. prakt. Chemie, vol. 42, p. 97, 1847.

25. Wolframite from Altenberg, Germany. Kerndt, T., Ueber die Krystallform und chemische Zusammensetzung der natürlichen und künstlichen Verbindungen des Wolframmetalles: Jour. prakt. Chemie, vol. 42, p. 110, 1847.

26. Wolframite from Zinnwald, Germany. Schneider, R., Ueber die chemische Constitution des Wolframminerals: Jour. prakt. Chemie, vol. 49, p. 332, 1850.

27. Wolframite from Neubeschert-Glück, Freiberg, Germany. Kerndt, T., Ueber die Krystallform und chemische Zusammensetzung der natürlichen und künstlichen Verbindungen des Wolframmetalles: Jour. prakt. Chemie, vol. 42, p. 102, 1847.

28. Wolframite from Schlaggenwalde, Bohemia. Kerndt, T., Ueber die Krystallform und chemische Zusammensetzung der natürlichen und künstlichen Verbindungen des Wolframmetalles: Jour. prakt. Chemie, vol. 42, p. 109, 1847.

29. Wolframite from Zinnwald, Germany (?). Ebelmen, J. J., Note sur la composition du wolfram: Annales des mines, 4 th ser., vol. 4, p. 407, 1843.

30. Wolframite from Zinnwald, Germany. Kerndt, T., Ueber die Krystallform und chemische Zusammensetzung der natürlichen und künstlichen Verbindungen des Wolframmetalles: Jour. prakt. Chemie, vol. 42, p. 96, 1847. 
the wolframite series-Continued.

\begin{tabular}{|c|c|c|c|c|c|c|c|c|c|}
\hline \multirow{2}{*}{ No. } & \multicolumn{8}{|c|}{ Recalculatod analysis. } & \multirow{2}{*}{$\begin{array}{l}\text { Specific } \\
\text { gravity. }\end{array}$} \\
\hline & WOs. & $\mathrm{FeO}$. & MnO. & FeWOs. & MnWO4. & $\begin{array}{c}\text { Excoss } \\
\text { FeO. }\end{array}$ & $\begin{array}{l}\text { Excess } \\
\mathrm{WO}_{3} \text {. }\end{array}$ & CaWO4. & \\
\hline 19 & 76.5 & 4.8 & 18.7 & 20.3 & 79.7 & 0.5 & & & \\
\hline 2 & 76.6 & 5.4 & 18.0 & 23.0 & 77.0 & 0.0 & & & \\
\hline 21 & 76.5 & 6.4 & 17.1 & 27.1 & 72.9 & 4.6 & & $\ddot{5} .7$ & \\
\hline 22 & 76.5 & 7.1 & 16.4 & 30.1 & 69.9 & 4.3 & & & 7.017 \\
\hline 23 & 76.5 & $\ddot{7.5}$ & 16.0 & 31.5 & 68.5 & 1.9 & & & \\
\hline 24 & 76.5 & 8.5 & 15.0 & 35 & 64 & 1.2 & & & 7.2 \\
\hline 25 & 76.5 & 8.6 & 14.9 & 36. & 63.7 & 1.2 & & $\cdots$ & 7.1 \\
\hline 26 & 76.5 & 8.7 & 14. & 36 & 63.4 & 1.7 & $\cdots$ & 6.1 & \\
\hline 27 & 76.5 & 8.7 & 14.8 & 37.3 & 62.7 & .4 &. & & 7.229 \\
\hline 28 & 76.5 & 9.1 & 14.4 & 38.3 & 61.7 & .6 & . & & 7.535 \\
\hline $\begin{array}{l}29 \\
30\end{array}$ & $\begin{array}{l}76.5 \\
76.5\end{array}$ & $\begin{array}{l}9.1 \\
9.3\end{array}$ & $\begin{array}{l}14.4 \\
14.2\end{array}$ & $\begin{array}{l}38.4 \\
39.2\end{array}$ & $\begin{array}{r}61.6 \\
-\quad 60.8\end{array}$ & .8 & $\ldots \ldots$ & 2.5 & \\
\hline 31 & 76.5 & 9.4 & 14.1 & 39.8 & 60.2 & .5 & ........ & 11.7 & \\
\hline 32 & 76.5 & 9.9 & 13.6 & 41 & 58.1 & 2.6 & ... & 6.1 & \\
\hline 33 & 76.5 & 10.1 & 13.4 & 42.7 & 57.3 & 1.9 & $1 \ldots \ldots$ & 4.1 & $\ddot{7} \ddot{7} \ddot{272}$ \\
\hline 34 & 76.4 & 10.3 & 13.3 & 43.3 & 56.7 & .7 & & 1.5 & 7.000 \\
\hline 35 & 76.4 & 11.6 & 12.0 & 48.8 & 51.2 & 1.8 & $\therefore$ & ..... & \\
\hline 36 & 76.4 & 12.1 & 11.5 & 50.9 & 49.1 & 4.0 & ... & & \\
\hline $\begin{array}{l}37 \\
38\end{array}$ & $\begin{array}{l}76.4 \\
76.4\end{array}$ & $\begin{array}{l}12.1 \\
12.3\end{array}$ & $\begin{array}{l}11.5 \\
11.3\end{array}$ & $\begin{array}{l}51.1 \\
51.9\end{array}$ & $\begin{array}{l}48.9 \\
48.1\end{array}$ & $\begin{array}{l}1.9 \\
1.4\end{array}$ & (a) & 3.6 & \\
\hline
\end{tabular}

a Limonite 2.1 per cent.

31. Wolframite from Zinnwald, Germany. Weidinger, G., Analyse eines Wolframkrystalls aus den Gruben bei sä' hsisch Zinnwald an der böhmisch-sächsischen Grenze: Zeitschr. Pharm., vol. 7, p. 73, 1855.

32. Wolframite presumably from the property of the Mount Pima Mining Co. (Ltd.), Tenasserim, Lower Burma. A published analysis by $\mathrm{O}$. Burger furnished through the courtesy of Radcliff \& Co., Rangoon, Burma.

33. Wolframite from Cornwall, England. The exact locality of origin is unknown. Analysis by Edgar T. Wherry on specimen No. 80179 in the United States National Museum. The analysis, which will appear in the Proceedings of the Museum, showed, besides the items given: $\mathrm{Fe}_{2} \mathrm{O}_{3}, 0.70$, which was calculated to its equivalent of $\mathrm{FeO}$ and added to that item. The wolframite is black and opaque and occurs in large crystals with pyrite and chalcopyrite. A section showed a later deposition of very thin bands of scheelite and wolframite in cracks of the crystals, so that the $\mathrm{CaO}$ evidently should be calculated into scheelite.

34. Wolframite from Lost River, Alaska. R. C. Wells, of the U. S. Geol. Survey, analyst. No $\mathrm{Ta}, \mathrm{Cb}, \mathrm{Mo}$, or rare earths present.

35. Wolframite from between Vilate and Chanteloube, France. Damour, A., Sur le wolfram tantalifère du département de la Haute-Vienne: Soc. géol. France Bull., $2 \mathrm{~d}$ ser., vol. 5, p. 108, 1848.

36. Wolframite from Takatori mine, Takatori Mountain, near Sudzukoya, HigashiIbaraki County, State of Hitachi, Japan. The mine is 12 miles northwest of Mito and 14 miles northeast of Kasama. Analysis by S. Katsuno, personal communication, Nov. 30, 1912.

37. Wolframite from Black Metal claims, Hill City, S. Dak. R. C. Wells, of the U. S. Geol. Survey, analyst. $\mathrm{Any} \mathrm{Al}_{2} \mathrm{O}_{3}$ present is included with the $\mathrm{FeO}$.

38. Wolframite from the southern end of the Sierra Cordoba, Argentina. Bodenbender, G., Die Wolfram-Minen der Sierra von Córdoba in der Argentinischen Republik: Zeitschr. prakt. Geologie, Nov., 1894, p. 409. 
Analyses of minerals of

\begin{tabular}{|c|c|c|c|c|c|c|c|c|c|}
\hline \multirow{2}{*}{ No. } & \multirow{2}{*}{ Locality. } & \multicolumn{8}{|c|}{ Original analysis. } \\
\hline & & $\mathrm{WO}_{3}$ & Feo. & MnO. & $\mathrm{CaO}$. & $\mathrm{SiO}_{2}$ & MgO. & $\begin{array}{l}\text { Other sub- } \\
\text { stances. }\end{array}$ & Total. \\
\hline & WOLFRAMTTE-continued. & & & & & & & & \\
\hline 39 & Lead, S. Dak.......... & 61.70 & 9.18 & 8.21 & 0.93 & 12.87 & Trace. & & 99.64 \\
\hline $\begin{array}{l}40 \\
41\end{array}$ & Montebelleux, France........ & 76.21 & 12.87 & 10.52 & & .15 & & & 99.75 \\
\hline $\begin{array}{l}41 \\
42\end{array}$ & Sadisdorf, Germany ............ & 70.38 & \begin{tabular}{|c|}
13.88 \\
15
\end{tabular} & 9.52 & 2.16 & & & & 100.70 \\
\hline 43 & Tavoy, Burma.................... & 74.78 & 13.80 & 9.36 & Trace. & 30 & Trace. & $\mathrm{Cb}_{2} \mathrm{O}_{5}, 0.20$ & 100.12 \\
\hline 44 & Wheal Gorland, Cornwali.... & 51.00 & 20.20 & 6.07 & & 1.83 & & As, 3.82 . & \\
\hline 45 & Northwest Spain........ & 64.13 & 10.88 & 6.42 & 1.21 & 7.71 & 3.16 & $\mathrm{SnO}_{2}, 0.68$ & 99.89 \\
\hline & $\begin{array}{l}\text { Quebrada de la Viuda, } \\
\text { Argentina. }\end{array}$ & & & & & & & $\mathrm{Cb}_{2} \mathrm{O}_{3}, 1.12$. & 100.87 \\
\hline 47 & $\begin{array}{l}\text { Miramichi River, Now } \\
\text { Brunswick. }\end{array}$ & 74.43 & 16.90 & 8.37 & & & & & 99.70 \\
\hline & Altai, Siberia.................. & 75.56 & 16.22 & 8.42 & & & & & 100.20 \\
\hline $\begin{array}{l}49 \\
50\end{array}$ & 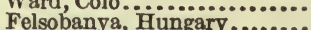 & $\begin{array}{l}71.27 \\
76.14\end{array}$ & 20.01 & $\begin{array}{l}7.15 \\
8.34\end{array}$ & 1.58 & $\cdots$ & & & 100.01 \\
\hline 51 & Perilhao, Portugal............ & 73.46 & 16.90 & 6.97 & ......... & 2.69 & & & 100.02 \\
\hline & Wheal Gorland, Cornwall.... & 57.18 & 15.87 & 5. 30 & & 6.83 & & As, 2.39. & \\
\hline
\end{tabular}

39. Wolframite from Two Strike mine, Yellow Creek, Lead, S. Dak. W. F. Hillebrand, analyst. Irving, J. D., Economic resources of the northern Black Hills: U. S. Geol. Survey Prof. Paper 26, p. 167, 1904. Besides the items noted, the analysis showed: $\mathrm{Fe}_{2} \mathrm{O}_{3}, 3.85 ; \mathrm{Al}_{2} \mathrm{O}_{3}, 0.52 ; \mathrm{SrO}, 0.02 ; \mathrm{BaO}, 0.04 ; \mathrm{K}_{2} \mathrm{O}+\mathrm{Na}_{2} \mathrm{O}+\mathrm{Li}_{2} \mathrm{O}, 0.08$; $\mathrm{H}_{2} \mathrm{O}$, below $105^{\circ}$ C., $0.20 ; \mathrm{H}_{2} \mathrm{O}$ above $105^{\circ} \mathrm{C} ., 0.87 ; \mathrm{As}_{2} \mathrm{O}_{5}, 1.25 ; \mathrm{P}_{2} \mathrm{O}_{5}, 0.12 ;$ traces of $\mathrm{V}_{2} \mathrm{O}_{5}$ and $\mathrm{S}$ or $\mathrm{SO}_{3}$. Extremely minute traces of $\mathrm{Zn}, \mathrm{Cu}$, Sb, and $\mathrm{Sn}$ were also found. Assays gave: Gold 0.05 ounce and silver 0.25 ounce to the ton of 2,000 pounds. The $\mathrm{P}_{2} \mathrm{O}_{5}$ was probably combined with $\mathrm{CaO}$ as apatite, and 0.18 has therefore been deducted from the $\mathrm{CaO}$ before combining it with $\mathrm{WO}_{3}$ for scheelite. The $\mathrm{FeO}$ is not sufficient, as indicated by the analysis, to combine with the $\mathrm{WO}_{3}$, and 0.6 must be taken from the $\mathrm{Fe}_{2} \mathrm{O}_{3}$ to supply the deficiency. A partial analysis of a specimen from the Harrison mine, near Lead, is given, as follows: $\mathrm{SiO}_{2}, 9.60 ; \mathrm{WO}_{3}, 61.70 ; \mathrm{Fe}_{2} \mathrm{O}_{3}$ and $\mathrm{FeO}, 12.67$, $\mathrm{MnO}, 7.21 ; \mathrm{CaO}, 5.39$. Recalculated: $\mathrm{WO}_{3}, 76.5 ; \mathrm{FeO}, 9.5 ; \mathrm{MnO}, 14.0 ; \mathrm{FeWO}_{4}$; 40.2; $\mathrm{MnWO}_{4}, 59.8 ; \mathrm{CaWO}_{4}, 39.4$. In this analysis the $\mathrm{CaO}(5.39)$ is high, and no determination of $\mathrm{P}_{2} \mathrm{O}_{5}$ is indicated. There is no corresponding increase in the $\mathrm{WO}_{3}$ and the relation of the $\mathrm{FeO}: \mathrm{MnO}$ is so much different as to indicate that part of the lime probably belongs in apatite. Specimens of ore collected by the present writer from this general locality and examined microscopically show apatite in small quantity. As given, the analysis falls between Nos. 31 and 32 .

40. Wolframite from Montebelleux, Brittany, France. Bourion, F., Sur un mode général de préparation des chlorures anhydres et ses applications à l'analyse chimique: Annales chim. phys., 8th ser., vol. 21, p. 103, 1910.

41. Wolframite from the Kupfergrube, Sadisdorf, Germany. Winter, H., Ueber Vorkommen und Reindarstellung des Scandiums: Inaugural-Dissertation, FriedrichWilhelms-Universität zu Berlin, p. 23, 1911. Besides the items mentioned, the analysis shows $\mathrm{PO}_{4}, 2.23 ; \mathrm{MoO}_{3}$, trace; earth acids $\left(\mathrm{TaO}_{2}, \mathrm{TiO}_{2}\right), 2.07 ; \mathrm{PbO}, 0.46 ; \mathrm{Sc}, 0.2$. It is stated that calcium phosphate was present in the gangue, and the $\mathrm{CaO}$ has therefore been combined with the $\mathrm{PO}_{4}$, which it is hardly sufficient to satisfy.

42. Wolframite from the Kupfergrube, Sadisdorf, Germany. Winter, H., Ueber Vorkommen und Reindarstellung des Scandiums: Inaugural-Dissertation, FriedrichWilhelms-Universität zu Berlin, p. 22, 1911. The analysis also showed: $\mathrm{TiO}_{2}$ and $\mathrm{TaO}_{2}, 0.63 ; \mathrm{PbO}$ and $\mathrm{SnO}_{2}, 0.47 ; \mathrm{Sc}, 0.2$.

43. Wolframite from the Tavoy district, Lower Burma. Analysis by C. S. Fawcitt. Bleeck, A. W. G., On some occurrences of wolframite lodes and deposits in the Tavoy District of Lower Burma. India Geol. Survey Records, vol. 43, pt. 1, pp. 67-68, 1913. 
the wolframite series-Continued.

\begin{tabular}{|c|c|c|c|c|c|c|c|c|c|}
\hline \multirow{2}{*}{ No. } & \multicolumn{8}{|c|}{ Recalculated analysis. } & \multirow{2}{*}{$\begin{array}{l}\text { Specifle } \\
\text { gravity. }\end{array}$} \\
\hline & $\mathrm{WO}_{2}$ & FeO. & MnO. & $\mathrm{FeWO} 4$. & $\mathrm{MnWO}_{4}$. & $\begin{array}{c}\text { Excess } \\
\text { FoO. }\end{array}$ & $\begin{array}{l}\text { Excess } \\
\mathrm{WO}_{3} \text {. }\end{array}$ & $\mathrm{CaWO}_{4}$. & \\
\hline 39 & 78.4 & 128 & 108 & & & & & & \\
\hline 40 & 76.4 & 13.0 & $\begin{array}{l}10.8 \\
10.6\end{array}$ & $\begin{array}{l}54.1 \\
54.8\end{array}$ & $\begin{array}{l}45.9 \\
45.2\end{array}$ & & 0.2 & 4.0 & . \\
\hline 41 & 76.4 & 13. 2 & 10.4 & 55.8 & 44. 2 & $\ddot{i} \ddot{7}$ & & & \\
\hline 42 & 76.4 & 13.4 & 10.2 & 56.4 & 43. 6 & 3.0 & . & $\ddot{2} . \ddot{8}$ & \\
\hline 43 & 76. & 14.0 & 9.6 & 59 & 40.8 & .1 & .. & & \\
\hline $\begin{array}{l}44 \\
45\end{array}$ & $\begin{array}{l}76.4 \\
76.4\end{array}$ & $\begin{array}{l}14.8 \\
14.8\end{array}$ & $\begin{array}{l}9.1 \\
8.7\end{array}$ & $\begin{array}{l}61.0 \\
62.8\end{array}$ & $\begin{array}{l}39.0 \\
37.2\end{array}$ & (?) & $3 . i^{\circ}$ & $\dddot{6} \ddot{2}$ & ...... \\
\hline $\begin{array}{l}90 \\
46\end{array}$ & 76. & $\begin{array}{l}15.0 \\
15.0\end{array}$ & 8. & $\begin{array}{l}0.2 \\
63.2\end{array}$ & $\begin{array}{l}37.2 \\
36.8\end{array}$ & $\ddot{1.3}$ & 3.1 & $\begin{array}{l}0.2 \\
2.7\end{array}$ & $\cdots$ \\
\hline 47 & 76.4 & 15.0 & 8.6 & 63.3 & 36.7 & 2.3 & & & \\
\hline 48 & 76.4 & 15.1 & 8.5 & 63.6 & 36.4 & 1.3 & & & 6.968 \\
\hline 49 & 76.4 & 15.1 & 8.5 & 63.8 & 36.2 & 7.2 & ................ & 8.1 & 7 \\
\hline 51 & 76.4 & 16. & 7.3 & 69.0 & 31.0 & 1.2 & $\ldots$ & $\ldots$ & \\
\hline & 76.4 & 16.6 & 7.0 & 70.0 & 30.0 & & & & \\
\hline
\end{tabular}

Besides the items noted in the table, the analysis shows $\mathrm{Al}_{2} \mathrm{O}_{3}, 0.81 ; \mathrm{Bi}_{2} \mathrm{O}_{3}, 0.14$; $\mathrm{SnO}_{2}$, trace; $\mathrm{MoO}_{3}, 0.51 ; \mathrm{H}_{2} \mathrm{O}, 0.22$.

44. Ore from Wheal Gorland, Cornwall. Analysis by B. Kitto, communicated by Mr. R. Woodward, managing director of Edgar Allen \& Co. (Ltd.), Sheffield, England. The analysis also shows: $\mathrm{Pb}, 0.10 ; \mathrm{Mg}$, trace; $\mathrm{Bi}, 0.15 ; \mathrm{P}$, trace; $\mathrm{CaF}_{2}, 4.06 ; \mathrm{Cu}, 0.88$; $\mathrm{S}, 2.02 ; \mathrm{Al}_{2} \mathrm{O}_{3}, 1.77 ; \mathrm{SnO}_{2}, 8.64 ; \mathrm{O}$, by difference, 3.96. $\mathrm{Cu}, \mathrm{Fe}, \mathrm{S}$, and As were combined as nearly as possible to form chalcopyrite and arsenopyrite. Although not made on as pure material as might be wished for the purposes of this paper, the analysis shows approximately the composition of the wolframite.

45. Wolframite from northwest Spain (ore). Steinhart, O. J., Classification, occurrence, identification, and properties of tungsten ores: Mineral Industry, vol. 17, p. 830, 1909. Tha analysis also shows: $\mathrm{Al}_{2} \mathrm{O}_{3}, 5.32$; and $\mathrm{CrO}, 0.38$.

46. Wolframite from Quebrada de la Viuda, Department of San Xavier, Argentina. Bodenbender, G., Die Wolfram-Minen der Sierra von Córdoba in der Argentinischen Republik: Zeitschr. prakt. Geologie, Nov., 1894, p. 409. A trace of CaO is present but no $\mathrm{MgO}$.

47. Wolframite from the confluence of the southwest Miramichi and Burnt Hill Brook, New Brunswick. Walker, T. L., Recently discovered wolframite deposits in New Brunswick: Econ. Geology, vol. 6, p. 397, 1911.

48. Wolframite from Kolywanowschen mine, Altai, Siberia. Beck, W., and Teich, N., Ueber Wolfram und Scheelit aus Fundörten Russlands: Russ.-k. mineral. Gesell. St. Petersburg Verh., 2d ser., vol. 4, p. 317, 1869.

49. Wolframite from Ward, Colo. Analysis by J. B. Ekeley. George, R. D., The main tungsten area of Boulder County, Colo.: Colorado Geol. Survey First Rept., p. $43,1909$.

50. Wolframite from Felsobanya, Hungary. Sipöcz, L., Ueber die chemische Zusammensetzung einiger seltener Minerale aus Ungarn: Min. pet. Mitt., new ser., vol. 7, p. $270,1886$.

51. Wolframite from Perilhao, Portugal. Bourion, F., Sur un mode général de préparation des chlorures anhydres et ses applications a l'analyse chimique: Annales chim. et phys., 8th ser., vol. 21, p. 104, 1910.

52. Ore from Wheal Gorland, Cornwall. Analysis by B. Kitto, communicated by Mr. R. Woodward, managing director of Edgar Allen \& Co. (Ltd.), Sheffield, England. $\mathrm{Fe}(12.34)$ has been calculated as $\mathrm{FeO}$ (15.87). The analysis also shows: $\mathrm{SnO}_{2}, 2.75$; traces of $\mathrm{Pb}$ and $\mathrm{MgO} ; \mathrm{CaF}_{2}, 4.37 ; \mathrm{Cu}, 0.45 ; \mathrm{S}, 1.31 ; \mathrm{Al}_{2} \mathrm{O}_{3}, 4.13$; and $\mathrm{O}$, by difference, 2.95 . 
Analyses of minerals of

\begin{tabular}{|c|c|c|c|c|c|c|c|c|c|}
\hline \multirow{2}{*}{ No. } & \multirow{2}{*}{ Locality. } & \multicolumn{8}{|c|}{ Original analysis. } \\
\hline & & $\mathrm{WO}_{3}$. & FeO. & MnO. & $\mathrm{CaO}$. & $\mathrm{SiO}_{2}$. & MgO. & $\begin{array}{l}\text { Other sub- } \\
\text { stances. }\end{array}$ & Total. \\
\hline & WOLFRAMITE-continued. & & & & & & & & \\
\hline 53 & Meymac, France. . & 74.75 & 16.17 & 6. 40 & 0.40 & 1.12 & 0.17 & $\mathrm{a}_{2} \mathrm{O}_{5}, 0.9$ & 99.96 \\
\hline 54 & .....do....................... & 74.25 & 15.85 & 6.51 & .80 & & .04 & \{ & 99.25 \\
\hline $\begin{array}{l}55 \\
56\end{array}$ & $\begin{array}{l}\text { Oreville, S. Dak.............................. } \\
\text { Carrock Fell, England... }\end{array}$ & $\begin{array}{l}76.00 \\
76.24\end{array}$ & $\begin{array}{l}17.00 \\
16.39\end{array}$ & $\begin{array}{l}6.60 \\
6.05\end{array}$ & $\begin{array}{r}.20 \\
1.05\end{array}$ & .90 & $\begin{array}{r}\text { None. } \\
.11\end{array}$ & & $\begin{array}{r}100.70 \\
99.84\end{array}$ \\
\hline 57 & Mount Carbine, Queensland. & 71.2 & 18.0 & 6.0 & & 4.0 & & 0. & \\
\hline 58 & Gordon Gulch, Colo.. & 60.84 & 18.36 & 4.73 & & 16.28 & & & \\
\hline 59 & Cabarrus County, N. C. . & 75. 79 & 19.80 & 5.35 & .32 & & & $\mathrm{SnO}_{2}$, trace. & 101.26 \\
\hline 60 & Neudorf, Germany...... & 76.21 & 18.54 & 5.23 & .40 & & .36 & & 100.74 \\
\hline 61 & Pioche, Nev ............... & 70.73 & 16.42 & 4.71 & .50 & .2 & .14 & $(\mathrm{Ta}, \mathrm{Cb})_{2} \mathrm{O}_{5}, 0.82$ & 97.08 \\
\hline 62 & Irish Creek, Va........... & 74.56 & 15.19 & 3.84 & 4.10 & & .41 & $(\mathrm{Ta}, \mathrm{Cb})_{2} \mathrm{O}_{5}$, etc. & 100.20 \\
\hline 63 & Stassberg, Germany. & 76.57 & 18.98 & 4.90 & .70 & & Trace. & & 101.15 \\
\hline 64 & Cedar Canyon, Wash. & 75.73 & 18.68 & 4.93 & ..... & .36 &..... & Undet., $0.22 .$. & 99.92 \\
\hline 65 & Chanteloube, France. & 75.82 & 19.33 & 4.84 & & & & 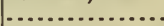 & 99.99 \\
\hline 66 & Harzgerode, Germany. & 75.90 & 19.25 & 4. 80 & & & & & 99.95 \\
\hline 67 & Monte Video.. & 76.02 & 19.21 & 4.75 & & & & & 99.98 \\
\hline
\end{tabular}

53. Wolframite from Meymac, Correze, France. Carnot, A., Sur quelques minéraux de tungstène de Meymac (Correze): Compt. Rend., vol. 79, p. 638, 1874 . Any alumina present is included with the silica.

54. Wolframite from Meymac, Correze, France. Carnot, A., Sur quelques minéraux de tungstène de Meymac (Correze): Compt. Rend., vol. 79, p. 638, 1874.

55. Wolframite from "Wolfram" claim, 3 miles east of Oreville, S. Dak. R. C. Wells, of the U. S. Geol. Survey, analyst. $\mathrm{SiO}_{2}$ includes any other insolubles. Ta, $\mathrm{Cb}, \mathrm{Sn}, \mathrm{Mo}$, and rare earths are not present in appreciable quantities.

56. Wolframite from Carrock Fell, England. Finlayson, A. M., The ore-bearing pegmatites of Carrock Fell and the genetic significance of tungsten ores: Geol. Mag., vol. 7, p. 21, 1910.

57. Wolframite. Analysis of "typical Mount Carbine [Queensland] wolfram concentrate" by Alex. Cumming. The $\mathrm{SiO}_{2}$ (4.0) includes "insol., etc." Besides the items in the table there is also "undetermined, 0.5." Quoted by Ball, L. C., Wolfram mines of Mount Carbine. No. 1: Queensland Govt. Min. Jour., vol. 14, p. 70, 1913.

58. Ore from Gordon Gulch, Boulder County, Colo. Greenawalt, W. E., The tungsten deposits of Boulder County, Colo.: Eng. and Min. Jour., vol. 83, p. 951, 1907. The analysis also includes: Gold, trace; silver, 3.1 ounces to the ton. The item given under $\mathrm{SiO}_{2}$ is given by Greenawalt as " $\mathrm{Si}$."

59. Wolframite from the Flowe mine, Cabarrus County, N. C. Genth, F. A., The minerals of North Carolina: U. S. Geol. Survey Bull. 74, p. 80, 1891.

60. Wolframite from Grube Pfaffenberg, Neudorf, Harz Mountains, Germany. Schneider, R., Ueber die chemische Constitution des Wolfram-Minerals: Jour. prakt. Chemie, vol. 49, p. 334, 1850.

61. Black wolframite from Silver Comet mine, 11 miles west of Pioche, Nev. J. G. Dinwiddie, analyst; personal communication. The analysis also showed $\mathrm{Fe}_{2} \mathrm{O}_{3}, 2.92$; $\mathrm{H}_{2} \mathrm{O}$ below $110^{\circ} \mathrm{C}, 0.03 ; \mathrm{H}_{2} \mathrm{O}$ above $110^{\circ} \mathrm{C}$, 0.57 . The $\mathrm{FeO}$ of the analysis gave an 


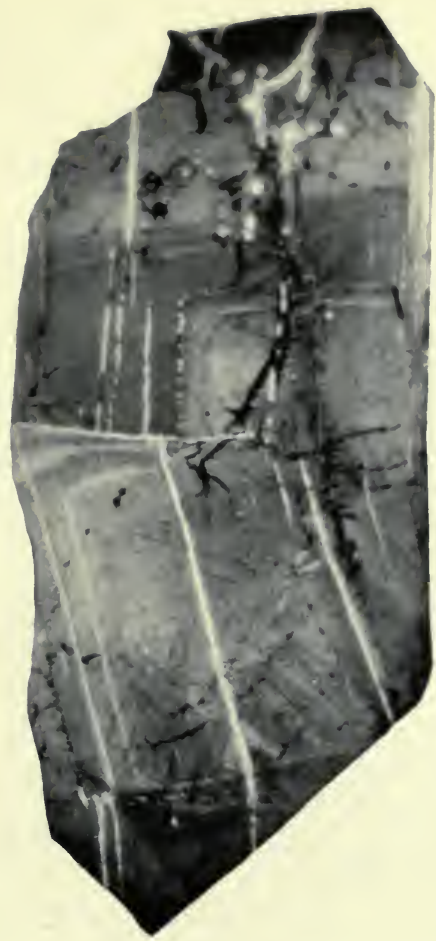

A. HÜBNERITE FROM THE DRAGOON MOUNTAINS, ARIZ.

Section showing zonal structure. $\times 5$.

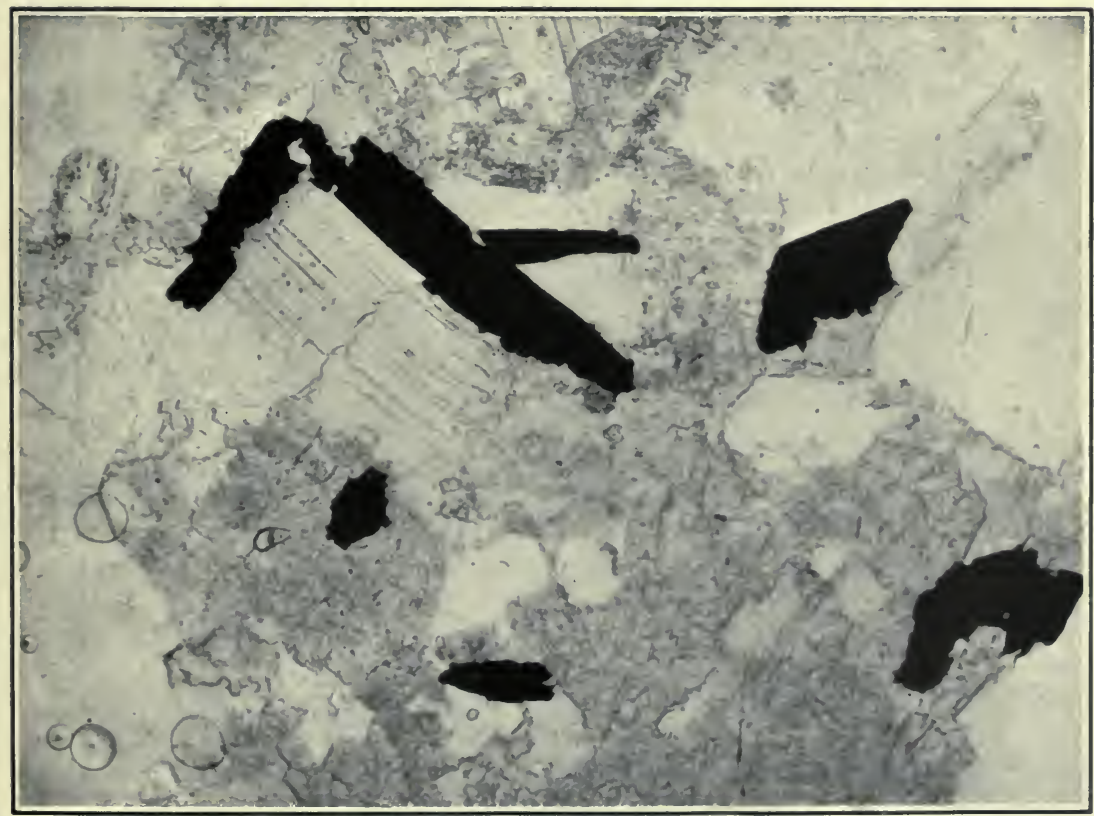

B. PHOTOMICROGRAPH OF GRANITE FROM WHETSTONE MOUNTAINS, ARIZ. Showing wolframite (black) with warty protuberances of scheelite. $\times 90$. 


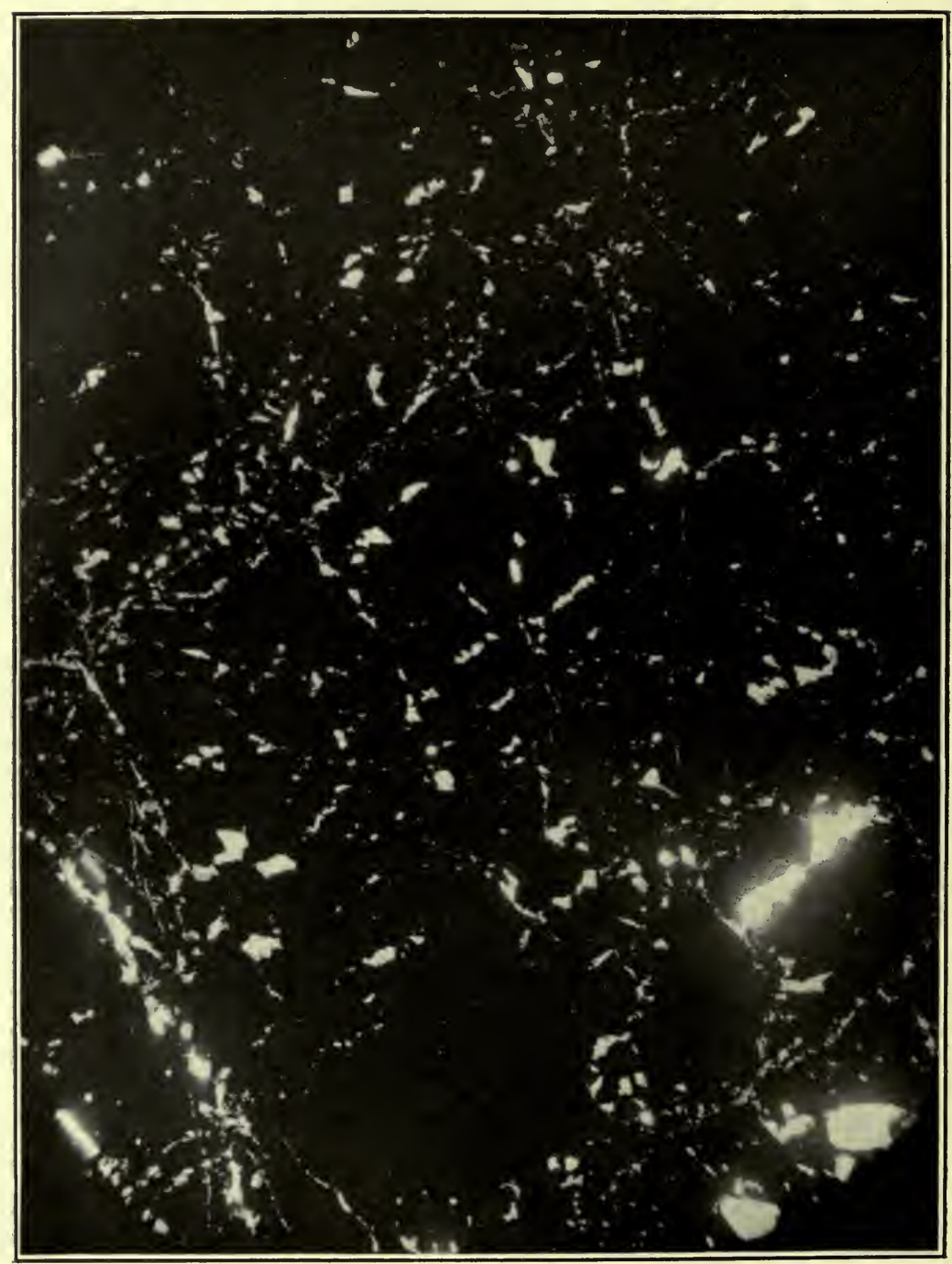

WOLFRAMITE FROM IRISH CREEK, VA.

Section showing interstitial scheelite. $\times 30$. 
the wolframite series-Continued.

\begin{tabular}{|c|c|c|c|c|c|c|c|c|c|}
\hline \multirow{2}{*}{ No. } & \multicolumn{8}{|c|}{ Recalculated analysis. } & \multirow{2}{*}{$\begin{array}{l}\text { Specific } \\
\text { gravity. }\end{array}$} \\
\hline & $\mathrm{WO}_{3}$ & FeO. & MnO. & FeWO4. & $\mathrm{MnWO}_{4}$. & $\begin{array}{c}\text { Excess } \\
\text { FeO. }\end{array}$ & $\begin{array}{l}\text { Excess } \\
\mathrm{WO}_{3} \text {. }\end{array}$ & CaWO. & \\
\hline 53 & 76.4 & 16.6 & 7.0 & 70.1 & 29.9 & 0.4 & ... & 4.1 & \\
\hline 54 & 76.4 & 16.9 & 6.7 & 71.4 & 28.6 & .1 & & 2.1 & ........... \\
\hline $\begin{array}{l}55 \\
56\end{array}$ & $\begin{array}{l}76.4 \\
76.4\end{array}$ & $\begin{array}{l}16.9 \\
17.2\end{array}$ & $\begin{array}{l}6.7 \\
6.4\end{array}$ & $\begin{array}{l}71.4 \\
72.5\end{array}$ & $\begin{array}{l}28.6 \\
27.5\end{array}$ & $\begin{array}{l}.4 \\
.2\end{array}$ & $\mid \ldots \ldots \ldots \ldots$ & $\begin{array}{l}1.0 \\
5.4\end{array}$ & $\begin{array}{r}6.70 \\
\ldots .6 .\end{array}$ \\
\hline 57 & 76.4 & 17.2 & 6.4 & 72.5 & 27.5 & 2.0 & $\ldots$ & ............ & $\ldots \ldots \ldots$ \\
\hline 58 & 76.4 & 17.7 & 5.9 & 74.6 & 25.4 & 4.3 & & ....... & $\ldots \ldots$ \\
\hline $\begin{array}{l}59 \\
60 \\
61 \\
62\end{array}$ & $\begin{array}{l}76.4 \\
76.4 \\
76.4 \\
76.3\end{array}$ & \begin{tabular}{l|l|l}
18.1 & \\
18.3 & \\
18.3 & \\
18.6 &
\end{tabular} & $\begin{array}{l}\mathbf{5 . 5} \\
\mathbf{5 . 3} \\
5.3 \\
\mathbf{5 . 1}\end{array}$ & $\begin{array}{l}76.6 \\
77.2 \\
77.4 \\
78.3\end{array}$ & $\begin{array}{l}23.4 \\
22.8 \\
22.6 \\
21.7\end{array}$ & $\begin{array}{r}2.1 \\
.6 \\
2.8 \\
1.2\end{array}$ & $\begin{array}{r}\ldots \ldots \ldots \\
\cdots \cdots \\
\cdots \cdots\end{array}$ & $\begin{array}{r}1.7 \\
2.1 \\
3.3 \\
21.1\end{array}$ & \begin{tabular}{r}
$\quad 7.496$ \\
$\ldots \ldots \ldots \ldots$ \\
\hdashline$\ldots \ldots \ldots$ \\
\hdashline$\ldots \ldots$. \\
\end{tabular} \\
\hline $\begin{array}{l}63 \\
64 \\
65 \\
66 \\
67\end{array}$ & $\begin{array}{l}76.3 \\
76.3 \\
76.3 \\
76.3 \\
76.3\end{array}$ & $\begin{array}{l}18.6 \\
18.7 \\
18.8 \\
18.9 \\
18.9\end{array}$ & $\begin{array}{l}5.1 \\
5.0 \\
4.9 \\
4.8 \\
4.8\end{array}$ & $\begin{array}{l}78.3 \\
78.8 \\
79.2 \\
79.4 \\
79.6\end{array}$ & $\begin{array}{r}21.7 \\
21.2 \\
20.8 \\
20.6 \\
20.4\end{array}$ & $\begin{array}{r}1.1 \\
.2 \\
.7 \\
.5 \\
.4\end{array}$ & 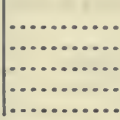 & $\begin{array}{l}3.6 \\
\cdots \cdots \\
\cdots \cdots \\
\cdots \cdots\end{array}$ & $\begin{array}{r}7.51 \\
7.228 \\
7.513\end{array}$ \\
\hline
\end{tabular}

excess of 0.2 and to this has been added 2.6, the equivalent of the $\mathrm{Fe}_{2} \mathrm{O}_{3}$ given. In appearance the material is so pure that it is difficult to account for the apparent presence of 3.3 per cent of scheelite $\left(\mathrm{CaWO}_{4}\right)$. Possibly the " $\mathrm{H}_{2} \mathrm{O}$ above $110^{\circ} \mathrm{C}$., 0.57 ," should be $\mathrm{CO}_{2}$.

62. Wolframite from Cash tin mine, Irish Creek, Rockbridge County, Va. Analysis by J. G. Dinwiddie. The analysis also shows $\mathrm{Fe}_{2} \mathrm{O}_{3}, 4.03 ; \mathrm{FeO}, 11.56 ; \mathrm{H}_{2} \mathrm{O}$ at $110^{\circ}, 0.12 ; \mathrm{H}_{2} \mathrm{O}$ above $110^{\circ}, 0.63 ; \mathrm{TiO}_{2}, 0.02 ; \mathrm{Al}_{2} \mathrm{O}_{3}, 0.32 ; \mathrm{CO}_{2}, 0.5$. The $\mathrm{Fe}_{2} \mathrm{O}_{3}$ has been changed to $\mathrm{FeO}$ and added to that item. It is extremely difficult to make accurate determinations of ferric and ferrous iron in the wolframites, owing to the likelihood of part of the iron being oxidized during grinding and difficulties inherent in the chemical determination. The change also makes the analysis foot up better. The scheelite $\left(\mathrm{CaWO}_{4}\right)$ is very high, (21.1), but specimens of wolframite from the locality show many inclusions of scheelite. (See Pl. XIV.)

63. Wolframite from Neuhaus Stollberg, Stassberg, Harz Mountains, Germany. Analysis by Petzold. Schneider, R., Ueber einen härzer Wolfram: Poggendorf's Annalen, 4th ser., vol. 3, p. 474, 1854.

64. Wolframite from the Germania mine, Cedar Canyon, Stevens County, Wash. R. C. Wells, of the U. S. Geol. Survey, analyst.

65. Wolframite from Chanteloube, Limoges, France. Kerndt, T., Ueber die Krystallform und chemische Zusammensetzung der natürlichen und künstlichen Verbindungen des Wolframmetalles: Jour. prakt. Chemie, vol. 42, p. 105, 1847.

66: Wolframite from Harzgerode, Germany. Kerndt, T., Ueber die Krystallform und chemische Zusammensetzung der natürlichen und künstlichen Verbindungen des Wolframmetalles: Jour. prakt. Chemie, vol. 42, p. 105, 1847.

67. Wolframite from "Monte Video," country not given, Kerndt, T., Ueber die Krystallform und chemische Zusammensetzung der natürlichen und kủnstlichen Verbindungen des Wolframmetalles: Jour. prakt. Chemie, vol. 42, p. 102, 1847. 
Analyses of minerals of

\begin{tabular}{|c|c|c|c|c|c|c|c|c|c|}
\hline \multirow{2}{*}{ No. } & \multirow{2}{*}{ Locality. } & \multicolumn{8}{|c|}{ Original analysis. } \\
\hline & & $\mathrm{WO}_{3}$. & $\mathrm{FeO}$. & MnO. & $\mathrm{CaO}$. & $\mathrm{SiO}_{2}$. & $\mathrm{MgO}$. & $\begin{array}{l}\text { Other sub- } \\
\text { stances. }\end{array}$ & Total. \\
\hline & FERBERITE. & & & & & & & & \\
\hline 68 & Limoges, France. & 76.20 & 19.19 & 4.48 & & & 0.80 & & 100.67 \\
\hline $\begin{array}{l}60 \\
69\end{array}$ & Traversella, Italy & 75.99 & 16.29 & 3. 45 & 4.03 & & & & 99.76 \\
\hline 70 & Nagpur, India... & 51.59 & 14.50 & 2.94 & . & 3.40 & & $\ddot{P}, 0.018$ & 72.45 \\
\hline 71 & Estremadura, Spain. & 72.93 & 22.70 & 4.10 & ........ & . & & -20.0 & 99.73 \\
\hline 72 & Inverell, New South Wales.. & 77.64 & 18.76 & 4.12 & & & & & 100.52 \\
\hline 73 & Neudorf, Germany... & 76.30 & 20.12 & 4.12 & .38 & & .16 & & 101.08 \\
\hline 74 & Torrington, New South Wales & 70.73 & 18.13 & 3.64 & 1.64 & & Trace. & Gangue, 5.55 & 99.69 \\
\hline 75 & Gordon Gulch, Colo........... & 61.80 & 16.36 & 3.12 & .35 & 15.93 & 1.71 & $\mathrm{Al}_{2} \mathrm{O}_{3}, 1.06 \ldots$ & 100.33 \\
\hline 76 & Neudorf, Germany. & 76.28 & 20.38 & 3.80 & .20 & $\ldots \ldots$ & .07 & & 100.73 \\
\hline 77 & Beaver Creek, Colo...... & 66.41 & 24.31 & 3.25 & & 6.00 & & & \\
\hline 78 & Cave Creek, Ariz....... & 73.74 & 18.18 & 3.37 & .24 & .72 & & $(\mathrm{Ta}, \mathrm{Cb})_{2} \mathrm{O}_{5}, 2.2$ & 99.79 \\
\hline 79 & Sierra Almagrera, Spain & 70.11 & 23.29 & 3.02 & 1.75 & & & $\mathrm{Cb}_{2} \mathrm{O}_{5}$, trace.. & 99.90 \\
\hline 80 & $\begin{array}{l}\text { Kootenay Belle mine, British } \\
\text { Columbia. }\end{array}$ & 74.90 & 17.75 & 2.75 & 1.52 & 1.02 & 2.66 & ................ & 100.60 \\
\hline 81 & Hill City, S. Dak......... & 70.94 & 17.61 & 2.71 & & 8.70 & & & 99.96 \\
\hline 82 & Sierra Almagrera, Spain.. & 69.06 & 25.97 & 2.17 & 1.52 & & & & 98.72 \\
\hline 83 & Adun-Tschilon, Sibería... & 75.55 & 21.31 & 2.37 & .26 & & .51 & & 100.00 \\
\hline 84 & Ivigtut, Greenland.. & 75.19 & 22.97 & 1.33 & & $\cdots$ & ...... & $\mathrm{Cb}_{2} \mathrm{O}_{5}, 0.76$ & 100.25 \\
\hline 85 & Last Chance, Col & 62.30 & 19.90 & .69 & .79 & 14. & & $\mathrm{Al}_{2} \mathrm{O}_{3} 1.3$ & 99.70 \\
\hline
\end{tabular}

68. Ferberite from Limoges, probably from Puy-les-Vignes. (See Lacroix, A., Minéra. logie de la France et de ses colonies, vol. 4, pt. 1, p. 285, footnote, 1910.) Ebelmen, J. J., Note sur la composition du wolfram: Annales des mines, 4th ser., vol. 4, p. 407, 1843.

69. Ferberite from Traversella, Italy. Bernoulli, F. A., Ueber Wolfram und einige seiner Verbindungen: Poggendorf's Annalen, 4th ser., vol. 21, p. 603, 1860.

70. Ferberite from Nagpur district, India. Analysis by Carnegie Steel Co. Quoted by Fermor, L. L., Note on an occurrence of wolfram in the Nagpur district, Central Provinces: India Geol. Survey Records, vol. 36, pt. 4, p. 309, 1908.

71. Ferberite from Estremadura, Spain. Analysis by Truchot quoted by Mennicke, Hans, Die Metallurgie des Wolfram, p. 18, 1911.

72. Ferberite from Inverell, County Gough, New South Wales. Liversidge, A., The minerals of New South Wales, p. 85, 1888.

73. Ferberite from Grube Meiseberg, Neudorf, Harz Mountains, Germany. Schneider, R., Ueber die chemische Constitution des Wolfram-Minerals: Jour. prakt. Chemie, vol. 49, p. 334, 1850.

74. Ferberite from the Bismuth mine, Torrington, New South Wales. Analysis by H. P. White quoted by Carne, J. E., The tungsten mining industry in New South Wales: New South Wales Geol. Survey Min. Res. No. 15, p. 70, 1912.

75. Ferberite from Gordon Gulch, Boulder County, Colo. Analysis quoted as having been made by the Colorado Tungsten Corporation. George, R. D., The main tungsten area of Boulder County, Colo.: Colorado Geol. Survey First Rept., p. 43, 1909.

76. Ferberite from Grube Meiseberg, Neudorf, Germany. Schneider, R., Ueber die chemische Constitution des Wolfram-Minerals: Jour. prakt. Chemie, vol. 49, p. $334,1850$.

77. Ore from Beaver Creek, Boulder County, Colo. Analysis given by Greenawalt, W. E., The tungsten deposits of Boulder County, Colo.: Eng. and Min. Jour., vol. 83 , p. 951, 1907. The analysis also gives: Gold, trace; silver, 1.2 ounces to the ton. The item given under $\mathrm{SiO}_{2}$ is designated in the original as " $\mathrm{Si}$."

78. Ferberite from Cave Creek, Maricopa County, Ariz., U. S. Nat. Mus. catalogue No. 87283. Analysis by Edgar T. Wherry. The mineral is black and opaque. The 
the wolframite series-Continued.

\begin{tabular}{|c|c|c|c|c|c|c|c|c|c|}
\hline \multirow{2}{*}{ No. } & \multicolumn{8}{|c|}{ Recalculated analysis. } & \multirow{2}{*}{$\begin{array}{l}\text { Specifio } \\
\text { gravity. }\end{array}$} \\
\hline & $\mathrm{WO}_{8}$. & $\mathrm{FeO}$. & MnO. & FeWO4. & $\mathrm{MnWO}_{4}$ & $\begin{array}{l}\text { Excess } \\
\text { FeO. }\end{array}$ & $\begin{array}{l}\text { Excess } \\
\text { WO }_{3} \text {. }\end{array}$ & $\mathrm{CaWO}_{4}$. & \\
\hline & & & & & & & & & \\
\hline $\begin{array}{l}68 \\
69 \\
70\end{array}$ & $\begin{array}{c}76.4 \\
76.4 \\
76.4\end{array}$ & $\begin{array}{l}19.1 \\
19.2 \\
19.3\end{array}$ & $\begin{array}{l}4.5 \\
4.4 \\
4.3\end{array}$ & $\begin{array}{l}80.8 \\
81.1 \\
81.5\end{array}$ & $\begin{array}{l}19.2 \\
18.9 \\
18.5\end{array}$ & $\begin{array}{l}0.1 \\
1.4 \\
1.5\end{array}$ & & 20.7 & \\
\hline 71 & 76.4 & 19.3 & 4 & $\begin{array}{l}81.7 \\
81.8\end{array}$ & $\begin{array}{l}18.3 \\
18.3\end{array}$ & 4.2 & & ... & $\because \cdots$ \\
\hline $\begin{array}{l}72 \\
73\end{array}$ & $\begin{array}{l}76.3 \\
76.3\end{array}$ & $\begin{array}{l}19.4 \\
19.5\end{array}$ & $\begin{array}{l}4.3 \\
4.2\end{array}$ & $\begin{array}{l}81.8 \\
82.1\end{array}$ & $\begin{array}{l}18.2 \\
17.9\end{array}$ & 111 & 3.7 & & $\cdots \cdots$ \\
\hline 74 & 76.35 & $\begin{array}{l}19.0 \\
19.7\end{array}$ & $\begin{array}{l}4.2 \\
3.95\end{array}$ & 83.1 & 16.9 & ..... & 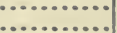 & .0 & (n...... \\
\hline 75 & 76.3 & 19.8 & $\begin{array}{l}3.9 \\
3.8\end{array}$ & $\begin{array}{l}83.4 \\
83.6\end{array}$ & 16.6 & .8 & $\cdots . .$. & 1.8 & $\cdots \ldots$ \\
\hline 77 & 76.3 & 19.9 & 3.8 & 84.0 & 16.0 & 7.0 & & & \\
\hline 78 & 76.3 & 20.0 & 3.7 & 84.2 & 15.8 & & 3.1 & 1.2 & 7.162 \\
\hline $\begin{array}{l}79 \\
80\end{array}$ & $\begin{array}{l}76.3 \\
76.3\end{array}$ & $\begin{array}{l}20.0 \\
20.5\end{array}$ & $\begin{array}{l}3.7 \\
3.2\end{array}$ & & $\begin{array}{l}15.7 \\
13.6\end{array}$ & 5.4 & $\dddot{2.4}$ & $\begin{array}{l}9.0 \\
7.8\end{array}$ & \\
\hline 81 & & 20.5 & & & & & 5,4 & & \\
\hline 82 & 76.3 & 21.0 & 2.7 & 88.7 & 11.3 & 8.7 & ..... & 7.0 & \\
\hline 83 & $\begin{array}{l}76.3 \\
766.3\end{array}$ & 21.3 & 2.4 & 89.6 & 10.4 & .6 & ............... & 1.3 & 6.405 \\
\hline $\begin{array}{l}84 \\
85\end{array}$ & $\begin{array}{l}76.3 \\
76.3\end{array}$ & $\begin{array}{l}22.8 \\
22.8\end{array}$ & $\begin{array}{r}1.4 \\
.9\end{array}$ & $\begin{array}{l}94.2 \\
96.1\end{array}$ & $\begin{array}{l}5.8 \\
3.9\end{array}$ & $\begin{array}{l}1.0 \\
2.3\end{array}$ & $\ldots$ & 4.1 & \\
\hline
\end{tabular}

analysis shows also $\mathrm{CuO}, 1.34 ;{ }^{\prime} \mathrm{Ta}_{2} \mathrm{O}_{5}$, approximately 1.50 , and $\mathrm{Cb}_{2} \mathrm{O}_{5}, 0.70$, judging from density of oxides." The quantity of tantalic and columbic pentoxides indicated is unusually high. The excess $\mathrm{WO}_{3}$ shown seems to be combined with part of the $\mathrm{CuO}$ to form a hydrous copper tungstate new to science. Work is now being undertaken on this mineral. Part of the copper is probably combined with the $\mathrm{SiO}_{2}$ as chrysocolla.

79. Ferberite from the Sierra Almagrera, southern Spain. Liebe, K. L. T., Ein neuer Wolframit; ein Beitrag zur Mineral-Chemie: Neues Jahrb., 1863 p. 645,. The analysis also shows $\mathrm{Al}_{2} \mathrm{O}_{3}, 1.15$; limonite, $1.39 ; \mathrm{SnO}_{2}, 0.14 ; \mathrm{GlO}$, trace. The analysis as given follows Dana's recalculation after subtracting the limonite (System of Mineralogy, p. 985). The specific-gravity determination is stated to have been made by Breithaupt.

80. Ferberite from Kootenay Belle mine, Salmo, British Columbia. Walker, T. L., Report on the tungsten ores of Canada: Canadian Dept. Mines, Mines Branch, p. 38, 1909.

81. Ferberite from the American Tungsten Co.'s mine, Hill City, S. Dak. Analysis made at the South Dakota School of Mines. Quoted by C. H. Fulton in a private report on the mine. Traces of $\mathrm{SnO}_{2}$ and $\mathrm{S}$ were found. If the quantities given are otherwise correct, it seems probable that a part of the substance determined as " $\mathrm{SiO}_{2}$ " is really $\mathrm{CaO}$; hence the excess of $\mathrm{WO}_{3}$.

82. Ferberite from the Sierra Almagrera, southern Spain. Rammelsberg, C. F., Ueber die chemische Zusammensetzung des Ferberits: K. preuss. Akad. Wiss. Berlin Monatsber., p. 175, 1865.

83. Ferberite from Adun-Tschilon, Siberia. Average of four analyses. Beck, W., and Teich, N., Ueber Wolfram und Scheelit aus Fundörten Russlands: Russ.-k. mineral. Gesell. St. Petersburg Verh., 2d ser., vol. 4, p. 315, 1869.

84. Ferberite from Ivigtut, Greenland. Analysis by Chr. Christensen. Böggild, O. B., Mineralogia Groenland (Særtryke af Meddelelser om Grönland, vol. 32): Mineral. and Geol. Mus. Univ. Copenhagen, Contr. to Mineralogy No. 6, p. 182, 1905.

85. Ferberite from Last Chance, Boulder County, Colo. Analysis by J. B. Ekeley. George, R. D., The main tungsten area of Boulder County, Colo.: Colorado Geol. Survey First Rept., p. 42, 1909. 
Analyses of minerals of

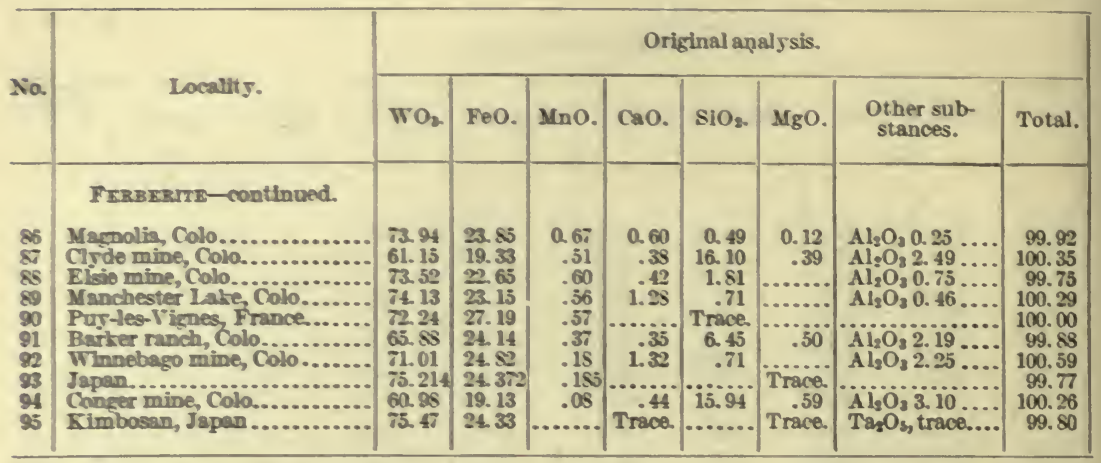

86. Ferberite from Magnolia, Boulder County, Colo. Analysis by J. B. Ekeley. George, R. D., The main tungsten area of Boulder County, Colo.: Colorado Geol. Survey First Rept., p. 42, 1909.

87. Ferberite from Clyde Mine, Nederland, Boulder County, Colo. Analysis by Ekeley, J. B., The composition of some Colorado tungsten ores: Colorado Univ. Studies, vol. 6, No. 2, p. 95, 1909.

88. Ferberite from Elsie mine, Boulder County, Colo. Analysis by J. B. Ekeley. George, R. D., The main tungsten area of Boulder County, Colo.: Colorado Geol. Survey First Rept., p. 42, 1909.

89. Ferberite from claim near Manchester Lake, Gilpin County, Colo. Analysis by J. B. Ekeley. George, R. D., The main tungsten area of Boulder County, Colo.: Colorado Geol. Survey First Rept., p. 42, 1909.

90. Ferberite from Puy-les-Vignes, France. Analysis by Nicolardot quoted by Lacroix, A., Minéralogie de la France et de ses colonies, vol. 4, pt. 1, p. 282, 1910. The analysis shows a trace of $\mathrm{SnO}_{2}$. 
the wolframite series-Continued.

\begin{tabular}{|c|c|c|c|c|c|c|c|c|c|}
\hline \multirow{2}{*}{ No. } & \multicolumn{8}{|c|}{ Recalculated analysis. } & \multirow{2}{*}{$\begin{array}{l}\text { Specific } \\
\text { gravily. }\end{array}$} \\
\hline & $\mathrm{WO}_{8}$. & $\mathrm{FeO}$. & Mno. & FeWO, & $\mathrm{MnWO}_{4}$. & $\begin{array}{l}\text { Excess } \\
\text { FeO. }\end{array}$ & $\begin{array}{l}\text { Excess } \\
\mathrm{WO}_{3} .\end{array}$ & $\mathrm{CaWO}_{4}$. & \\
\hline & & & & & & & & & \\
\hline $\begin{array}{l}\infty \\
87\end{array}$ & $\begin{array}{l}76.3 \\
76.3\end{array}$ & $\begin{array}{l}23.0 \\
23.0\end{array}$ & 0.7 & $\begin{array}{l}96.9 \\
97.2\end{array}$ & $\begin{array}{l}3.1 \\
2.8\end{array}$ & $\begin{array}{l}2.3 \\
1.3\end{array}$ & .. & 3.1 & ..... \\
\hline 88 & 76.3 & 23.1 & .6 & 97.3 & 2.7 & 1.1 & .......... & $\begin{array}{l}2.8 \\
2.6\end{array}$ & $\ldots$ \\
\hline 89 & 76.3 & 23.1 & .6 & 97.4 & 2.6 & 1.5 & & 6.6 & \\
\hline 90 & 76.3 & $\begin{array}{l}23.1 \\
23.1\end{array}$ & .6 & 97.5 & 2.5 & 5.3 & & ..... & \\
\hline 91 & $\begin{array}{l}76.3 \\
76.3\end{array}$ & 23.3 & $\begin{array}{r}.4 \\
.2\end{array}$ & $\begin{array}{l}98.1 \\
99.1\end{array}$ & $\begin{array}{r}1.9 \\
.9\end{array}$ & $\begin{array}{l}4.5 \\
4.6\end{array}$ & & 6.8 & . \\
\hline 93 & $\begin{array}{l}76.3 \\
76.3\end{array}$ & $\begin{array}{l}23.5 \\
23.6\end{array}$ & .2 & $\begin{array}{l}99.2 \\
99.6\end{array}$ & 8 & 1.2 & & $\dddot{3}$ & 7.079 \\
\hline 95 & 76.3 & 23.7 & & 100.0 & & .8 & & 2.8 & 6.640 \\
\hline
\end{tabular}

91. Ferberite from the Barker ranch, Nederland, Boulder County, Colo. Analysis by J. B. Ekeley. George, R. D., The main tungsten area of Boulder County, Colo.: Colorado Geol. Survey First Rept., p. 42, 1909.

92. Ferberite from Winnebago mine, Gilpin County, Colo. Analysis furnished by E. M. Green, Rollinsville, Colo. The original gives: $\mathrm{FeO}, 22.11$, and $\mathrm{Fe}_{2} \mathrm{O}_{3}, 3.01$. The ferric oxide has been calculated to its equivalent of ferrous oxide, and this seems to accord better with the remainder of the analysis.

93. Analysis of a pseudomorph of ferberite (reinite) after scheelite from Otomezaka or Kurasawa, Japan, by F. Kodera. Quoted by Tsunashiro Wada, Minerals of Japan (translated by Takudzi Ogawa), p. 77, 1904.

94. Ferberite from Conger mine, Nederland, Boulder County, Colo. Analysis by Ekeley, J. B., The composition of some Colorado tungsten ores: Univ. Colorado Studies, vol. 6, p. 95, 1909.

95. Ferberite (reinite) replacing scheelite, from Kimbosan, Kei, Japan. Analysis by E. Schmidt. Quoted by Luedecke, Otto, Ueber Reinit, K. v Fritsch, Ein neues Wolframsäures Eisenoxydul: Neues Jahrb., 1879, p. 288. 


\section{CONSIDERATION OF THE ANALYSES.}

The collection of analyses just given indicates an essentially complete series of mixtures of manganese and iron tungstates ranging from pure manganese tungstate to pure iron tungstate, with the possible number of members limited only by the number of specimens analyzed and by the accuracy of the determinations. The series is analogous to those of the plagioclase feldspars and the columbite-tantalite group. The greatest difference between consecutive analyses in either hübnerite or wolframite molecules is 5.5 per cent, which is found between the wolframites from Lost River, Alaska (No. 34), and Vilate, France (No. 35), which contain, respectively, as recalculated, 56.7 per cent and 51.2 per cent $\mathrm{MnWO}_{4}$, but there can be little doubt that analyses of other specimens from these or other localities would fall within the gap. It is also probable that if the exact quantity of iron and manganese combined as tungstates were known, the results would be considerably different. Most writers on the subject have treated the wolframites as definite compounds of $\mathrm{FeWO}_{4}$ and $\mathrm{MnWO}_{4}$, bearing relations to each other which could be expressed by small whole numbers, but this does not seem to be borne out by the analyses. Groups of analyses of wolframites from Zinnwald, from the Boulder district, and from the Black Hills, all small areas, show a very considerable variation in the ratio of iron and manganese bearing molecules. Those from Zinnwald range from 77.0 per cent to 60.2 per cent $\mathrm{MnWO}_{4}$, and those from Boulder County range from 36.2 per cent to 0.4 per cent $\mathrm{MnWO}_{4}$. In some crystals of hubnerite a considerable variation in color, probably due to difference in composition of different zones, can be seen. Were it not for the black color of each part, a zonal growth similar to that of porphyritic plagioclase feldspars could probably be observed in many wolframite crystals. (See PI.XIII, p. 30.) As stated in another place by W. T. Schaller, no difference in crystal form can be noticed between the two ends of the series. If there were a series of definite compounds between the two end members, some expression of the fact would probably be found in the facial angles.

Attention is called to the number of wolframites whose analyses show the presence of tantalum and columbium. It is probable that in some analyses, particularly the earlier ones, other substances have been determined as these elements, and in other analyses they have not been recognized or determined when present. Dr. Eberhard showed spectroscopically (p. 18) that columbium was present in a specimen of Boulder County ferberite, but he made no test for tantalum. Where one element is present, however, the other is almost sure also to be there. 
Tantalum and columbium are common in wolframites and their commercial possibilities have been investigated rather extensively. ${ }^{1}$ Mennicke mentions 1.5 per cent as the highest content of the oxides known in wolframites, but the ferberite from Cave Creek, Ariz., carries 2.2 per cent of the combined $\mathrm{Ta}_{2} \mathrm{O}_{5}$ and $\mathrm{Cb}_{2} \mathrm{O}_{5}$, according to Wherry's analysis. The form in which these oxides are present is not positively known, but it seems probable that, as suggested by Damour, ${ }^{2}$ they occur as minute particles of columbite. In the ferberite of Cave Creek irregularities in cleavage faces seem to be due to the presence of small bodies of a different black opaque mineral which may be columbite. I hope to do further work upon this subject.

\section{DEFINITION OF FERBERITE AND OTHER MEMBERS OF THE WOLFRAMITE SERIES.}

The continuity of the wolframite series as indicated by the analyses quoted shows that its customary division into hübnerite, wolframite, and ferberite must of necessity be arbitrary. The analysis on which the species ferberite is based (No. 79) gives a content of 3.02 per cent $\mathrm{MnO}$, equivalent to 3.7 per cent $\mathrm{MnO}$ or 15.7 per cent $\mathrm{MnWO}_{4}$ after recalculation. Great accuracy can not be claimed for the figures showing the constituent molecules, as the material was impure. In defining the species it can hardly be held that 3.07 per cent $\mathrm{MnO}$ or 15.7 per cent $\mathrm{MnWO}_{4}$ must mark the extreme limit of $\mathrm{Mn}$ allowable in ferberite. As by common usage the wolf ramite series is divided into three groups, 20 per cent $\mathrm{MnWO}_{4}$ seems to be a convenient and reasonable limit to place upon the $\mathrm{MnWO}_{4}$ allowable in a ferberite, and convenience would seem to indicate for hübnerite a similar limit of 20 per cent for its content of iron tungstate, $\mathrm{FeWO}_{4}$. For the mixtures between these end members the older term wolframite may properly be retained, and this term may well serve also as a general or field name. for the members of the series which can not be definitely identified.

I therefore propose the following definitions for the members of the wolframite series:

Ferberite: A monoclinic iron tungstate having when pure the composition $\mathrm{FeWO}_{4}$. It may contain not more than 20 per cent of the hübnerite molecule, $\mathrm{MnWO}_{4}$.

Hübnerite: A monoclinic manganese tungstate having when pure the composition $\mathrm{MnWO}_{4}$. It may contain not more than 20 per cent of the ferberite molecule, $\mathrm{FeWO}_{4}$.

\footnotetext{
1 Mennicke, Hans, Die Metallurgie des Wolframs, pp. 125-130, 1911.

2 Damour, A., Sur le wolfram tantalifère du département de lä Haute-Vienne: Soc. géol . France Bull., 2d ser., p. 108, 1848.
} 
Wolframite: A monoclinic mineral containing the ferberite molecule $\left(\mathrm{FeWO}_{4}\right)$ and the hübnerite molecule $\left(\mathrm{MnWO}_{4}\right)$ in all proportions between 20 per cent $\mathrm{FeWO}_{4}$ and 80 per cent $\mathrm{MnWO}_{4}$, and 80 per cent $\mathrm{FeWO}_{4}$ and 20 per cent $\mathrm{MnWO}_{4}$.

Under this scheme the analyses show ferberites from 13 widely separated localities-Boulder County, Colo., Cave Creek, Ariz., and Hill City, S. Dak., in the United States; British Columbia; Greenland; France; Saxony; Italy; Sierra Almagrera and Estremadura, Spain; New South Wales; India; Siberia; and Japan. The ferberite of Japan was described as reinite and replaces scheelite. From Limoges, France (No. 68), is shown a ferberite that contains nearly the maximum amount of manganese. The purest ferberite, showing no manganese and only a small excess of iron oxide ( 0.8 per cent), is that from Japan. Minerals from Gordon Gulch (No. 58) and Ward (No. 49), in the Boulder tungsten field, fall well within the wolframites, although from the most remarkable ferberite locality known. They merely emphasize the characteristic variability of the hübneriteferberite mixture.

\section{EXCESS OF FERROUS OXIDE AND MANGANOUS OXIDE.}

A point to which considerable importance has been attached by different writers is the excess of $\mathrm{FeO}$ in the ferberites, but the table of analyses shows that they are not unique in this, though some ferberites do carry large excesses of FeO.

The proneness of $\mathrm{WO}_{3}$ to form a lower oxide on heating and its solubility make it seem probable that many determinations of the oxide are low, so that the appearance of an excess of 0.1 or 0.2 per cent $\mathrm{FeO}$ may be neglected. It is also probable that in many of the analyses the $\mathrm{MnO}$ is too high, a common error when the determination is made gravimetrically, and a very small excess of $\mathrm{MnO}$ would cause a somewhat larger apparent excess in the $\mathrm{FeO}$. Only a few of the analyses show the presence of alumina, but many wolframites occur in a gangue containing muscovite or feldspar or both, and small quantities are likely to be mixed with the mineral analyzed. If the mineral is fused, the alumina, unless specially separated, will be precipitated with the iron oxide, and, if the iron is determined gravimetrically, will by so much make it appear larger.

Iron oxide is commonly present as such, for in the oxidized zone the breaking down of minerals such as siderite, pyrite, chalcopyrite, or wolframite setsfree iron oxide, which may formfilms over the residual wolframite or fill cavities of microscopic or larger size. A cut and polished crystal of brown ferberite from the Winnebago claim near Rollinsville shows a very porous structure (see $\mathrm{Pl}$. IV, $A, \mathrm{p} .13$ ) and the cavities are coated with hydrous iron oxide. This material is similar to that found on part of the Rogers tract and would surely give a 
considerable excess of iron on analysis. Specular hematite or magnetite, in particles too small to be easily distinguished, may occur in the ore, and the presence of one or both of these minerals may account for the surplus iron shown in some determinations.

In those wolframites which contain tantalum and columbium columbite may furnish a part of the apparent excess of iron. Microscopic examinations made by reflected light on polished and etched specimens of clean black ferberite show none of the differences in texture to be expected if such other minerals were present. There are, however, minute cavities which may be partly filled with iron minerals. Manganese dioxide, though in less quantity than iron oxides, is commonly associated with the ores, but its presence on the lighter-colored hübnerites should be easily distinguishable. The possibility of $\mathrm{FeO}$ and $\mathrm{MnO}$ being held in solid solution in the minerals of the wolframite series suggests itself, but no proof of this has been found.

It is to be noted that if the analyses given had been recalculated by first satisfying the $\mathrm{FeO}$ with $\mathrm{WO}_{3}$, and then combining the remainder of the $\mathrm{WO}_{3}$ with the $\mathrm{MnO}$, the excess of the $\mathrm{FeO}$ would disappear in most of the analyses and there would be an excess of $\mathrm{MnO}$. However, as just stated, manganese oxide occurs with the wolframites in much less quantity than iron oxide, and for this reason in recalculating an analysis it is best to first satisfy the $\mathrm{MnO}$ with $\mathrm{WO}_{3}$. It appears, therefore, that though some of the wolframites may carry an excess of $\mathrm{FeO}$, and a few an excess of both $\mathrm{FeO}$ and $\mathrm{MnO}$, most if not all of the apparent excesses are due to impurities present in the material analyzed and to errors of analysis.

Many careful analyses of well-selected minerals and many examinations by metallographic methods must be made before a real excess of $\mathrm{FeO}$ or $\mathrm{MnO}$ in the wolframites can be demonstrated. 


\title{
CRYSTALLOGRAPHY OF FERBERITE FROM COLORADO.
}

\author{
By Waldemar T. Schaller.
}

\section{PREVIOUS PUBLICATIONS.}

The several papers mentioned by Mr. Hess in his part of this report give some general facts in regard to the habit and size of crystals of ferberite. Two other papers, by Warren and by Moses (see Bibliography, pp. 74-75), give descriptions of ferberite crystals which may have come from this locality. The crystal figured by Warren is said to have come from South Dakota, though he states that the exact locality could not be ascertained. From the appearance of the crysta] it is more likely to have come from Colorado than from South Dakota. The crystal figured and described by Moses as crystallized wolframite from Boulder County, Colo., is very similar to those here described.

These two papers are the only publications on the crystallography of the ferberite from Colorado that could be found.

\section{GENERAL CHARACTER OF THE CRYSTALS.}

MODE OF OCCURRENCE.

In the specimens examined the ferberite crystals are perched on the country rock in groups or they line or nearly fill the cavities or fissures in the matrix. Layers of ferberite several centimeters thick, consisting of crystals whose bases have coalesced, are found on the rock. Much of the ferberite, which at first glance seems to be massive, is found on closer inspection to be a granular compact mass of small crystals.

The crystals occur isolated as distinct individuals (Pls. VII, p. 18, and VIII, p. 19), in groups of parallel or nearly parallel individuals (Pls. IX, p. 20, and X, p. 21), or in confused masses consisting of numerous abutting and even penetrating crystals. Twins are common, though single untwinned crystals are far more plentiful. The nearly parallel groupings are of two kinds: (1) A group of flattened crystals which may depart several degrees from strict parallelism and which are joined by the $a(100)$ faces (fig. 1); and (2) crystals joined by the $c(001)$ faces and superposed, the line of demarcation of the 
different crystals being well shown by the irregular lines crossing the prism zone normal to the vertical striations (fig. 2). The distribution of the dome faces on several of the parallel groupings joined by the $a(100)$ face conclusively demonstrates that the crystals are not twinned.

Well-developed crystals are abundant, but many crystals are rounded and curved either in a single zone or throughout. The curving of the surfaces in a single zone is generally due to the marked development of the striations in the prism zone. (See fig. 9, p. 59.) The curving of the faces over an entire crystal is due to the nearly parallel

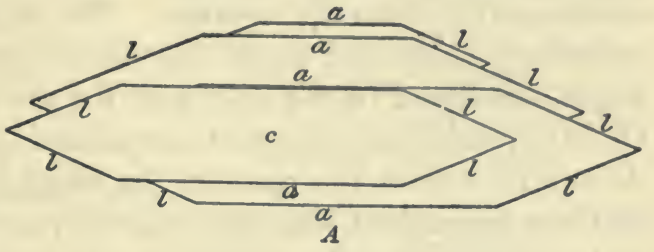
grouping of a number of crystals, each one deviating successively a little more from parallelism with the original unit.

The various forms of occurrence of ferberite found on the specimens examined may conveniently be summarized as follows:

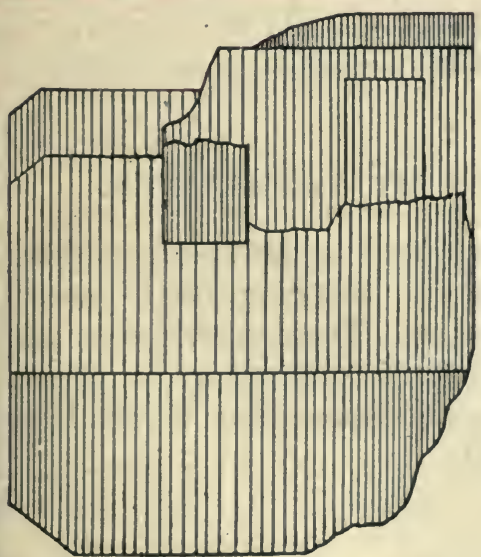

FigURE 2.-Superposed crystals, joined by the $c(001)$ faces. The line of demarcation is normal to the vertical striations on the large $a(100)$ faces.

1.5 centimeters long ( $b$ axis), half as high ( $c$ axis), and about 4 millimeters thick ( $a$ axis). The general average would be about 5 to 10 millimeters long, 2 to 5 millimeters high, and 1 to 3 millimeters thick. On

2, Bladed, indistinctly crystallized.

3 , Distinct individual crystals.

$a$, Single well-formed crystals (Pls. VII, VIII, XI, and XII, and text figs. 3-34).

$b$, Twinned crystals (Pl. VIII, $\mathbf{A}$, and text figs. 14, 15, 17, and 18).

$c$, Crystals grouped in parallel position (Pls. IX and X).

(1), Composition face $a(100)$ (fig. 1).

(2), Composition face $c(001)$ (fig. 2).

$d$, Rounded crystals or groups of crystals.

\section{SIZE.}

In size the crystals vary considerably. The largest seen were about

1, Massive. 
some of the rock specimens areas extending over many square centimeters are coated by minute crystals, few of which measure more than a millimeter in any direction. Most of the crystals measured were much smaller than the average. The dimensions of the crystals were accurately measured under the microscope, so that their proportions might be shown in the drawings for the text figures in this bulletin. Of 18 crystals thus accurately measured the $a$ axis lay between 0.3 and 0.7 millimeter on 14 crystals; the $b$ axis (which in most of these crystals has about half the true original value) between 0.5 and 2.5 millimeters on 16 crystals; and the $c$ axis between 1.0 and 3.5 millimeters on 13 crystals. The extreme values are: $a$ axis, 0.3 to 5.0 millimeters (the 5.0 is an extreme value, the next highest is only 1.5 ; all the other values are less than 1.0 millimeter); $b$ axis, 0.6 to 3.2 millimeters; $c$ axis, 0.3 to 3.8 millimeters.

Most of the crystals measured were bounded on one side by a cleavage face of $b(0 \overline{10})$, so that the sizes here given do not actually represent the size of the original crystals in the direction of the $b$ axis. In the illustrations (figs. 3 to 34 ) the crystals are generally shown relatively longer in the $b$ axis than the measured values indicate, in order to represent more truly their actual original sizes. The $b$ axis on many of the complete crystals was probably twice as great as measured.

\section{COLOR AND CLEAVAGE.}

The crystals are black and their luster is splendent, nearly metallic. The streak is dark brown, suggesting hematite. It is distinctly not black. Cleavage is clinopinacoidal, $b\{010\}$, very good, and commonly visible on the basal pinacoid.

\section{THE MEASURED CRYSTALS BY LOCALITIES.}

In the following table the crystals measured are grouped according to the mine from which they came. In addition their general character and habit are given for reference. These descriptions and localities are based entirely on the material collected by Mr. Hess. For other localities, not mentioned here, the papers given by Mr. Hess in his bibliography should be consulted. 
List of crystals by localities.

\begin{tabular}{|c|c|c|c|c|}
\hline $\begin{array}{c}\text { Crys- } \\
\text { tal } \\
\text { No. }\end{array}$ & Locality. & $\begin{array}{l}\text { Illus- } \\
\text { trated in } \\
\text { figure- }\end{array}$ & $\begin{array}{c}\text { Original } \\
\text { noto- } \\
\text { book No. }\end{array}$ & Description and hablt. \\
\hline $\begin{array}{r}1 \\
2 \\
3 \\
4 \\
5 \\
6 \\
7 \\
8 \\
9 \\
10 \\
11 \\
12\end{array}$ & $\begin{array}{l}\text { Crystals 1-12 from } 1 \text { specimpn of ore f:om the } \\
\text { loo-foot level of the Hoosiermine, Boulder County, } \\
\text { Colo. }\end{array}$ & $\begin{array}{r}4 \\
11 \\
10 \\
22 \\
23 \\
\ldots \ldots \\
\ldots \ldots \\
24 \\
14 \\
\ldots \ldots\end{array}$ & $\begin{array}{l}A_{1} \\
A_{2} \\
A_{3} \\
A_{1} \\
\mathbf{A}_{3} \\
A_{6} \\
A_{7} \\
A_{8} \\
A_{9} \\
A_{10} \\
\mathbf{A}_{11} \\
\mathbf{A}_{12}\end{array}$ & $\begin{array}{l}\text { 8, prismatic. } \\
\text { S, wedgelike. } \\
\text { S, prismatic. } \\
\text { s, wedgelike. } \\
\text { S, prismatic. } \\
\text { Do. } \\
\text { Do. } \\
\text { S, wedgelike. } \\
\text { S, prismatic. } \\
\text { T, tabular. } \\
\text { Do. } \\
\text { Do. }\end{array}$ \\
\hline $\begin{array}{l}13 \\
14 \\
15 \\
16 \\
17\end{array}$ & $\begin{array}{l}\text { Crystals } 13-17 \text { from } 1 \text { specimen from the Nugget } \\
\text { claim, } 5 \text { miles southeast of Nederland, } 1 \frac{1}{2} \text { miles } \\
\text { northeast of Rollinsville, Gilpin County, Colo: } \\
\text { Specimen taken from a 17-foot winze. }\end{array}$ & $\begin{array}{r}25 \\
\ldots \ldots \\
26 \\
27\end{array}$ & $\begin{array}{l}B_{1} \\
B_{2} \\
B_{3} \\
B_{4} \\
B_{5}\end{array}$ & $\begin{array}{l}\text { S, prismatic. } \\
\text { Do. } \\
\text { Do. } \\
\text { G, prismatic. } \\
\text { S, prismatic. }\end{array}$ \\
\hline $\begin{array}{l}18 \\
19 \\
20 \\
21 \\
22 \\
23 \\
24 \\
25 \\
26 \\
27\end{array}$ & $\begin{array}{l}\text { Crystals } 18-23,24-25,26-27 \text {, from three differen tspeci- } \\
\text { mens, all from the sam I claim as crystals } 13-17 \\
\text { (Nugget claim). }\end{array}$ & $\begin{array}{r}13 \\
33 \\
34 \\
\cdots\end{array}$ & $\begin{array}{l}\mathrm{C}_{1}-1 \\
\mathrm{C}_{1}-2 \\
\mathrm{C}_{1}-3 \\
\mathrm{C}_{1}-4 \\
\mathrm{C}_{1}-5 \\
\mathrm{C}_{1}-6 \\
\mathrm{C}_{2}-1 \\
\mathrm{C}_{2}-2 \\
\mathrm{C}_{3}-1 \\
\mathrm{C}_{3}-2\end{array}$ & $\begin{array}{l}\text { Do. } \\
\text { Do. } \\
\text { G, prismatic. } \\
\text { S, prismatic. } \\
\text { Do. } \\
\text { T, tabular. } \\
\text { S, rhombic. } \\
\text { Do. } \\
\text { Do. } \\
\text { T, tabular. }\end{array}$ \\
\hline $\begin{array}{l}28 \\
29 \\
30 \\
31 \\
32 \\
33 \\
34 \\
35\end{array}$ & $\begin{array}{l}\text { Crystals } 28-35 \text { from one specimen from Town Lot } \\
\text { mine, Nederland, Boulder County, Colo. }\end{array}$ & 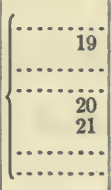 & $\begin{array}{l}\mathrm{C}_{8}-3 \\
\mathrm{D}_{1} \\
\mathrm{D}_{2} \\
\mathrm{D}_{3} \\
\mathrm{D}_{4} \\
\mathrm{D}_{5} \\
\mathrm{D}_{8} \\
\mathrm{D}_{7}\end{array}$ & $\begin{array}{l}\text { S, tabular. } \\
\text { S, wedgelike. } \\
\text { Do. } \\
\text { Do. } \\
\text { Do. } \\
\text { Do. } \\
\text { Do. } \\
\text { Do. }\end{array}$ \\
\hline $\begin{array}{l}36 \\
37\end{array}$ & From Black IIawk claim, Boulder County, Colo... & $\begin{array}{l}31 \\
32\end{array}$ & $\begin{array}{l}\mathbf{E}_{1} \\
\mathbf{E}_{2}\end{array}$ & $\begin{array}{l}\text { S, cubic. } \\
\text { Do. }\end{array}$ \\
\hline 38 & $\begin{array}{l}\text { From Georgia A. vein, } 2 \text { miles northeast of Nederland, } \\
\text { Boulder County, Colo. }\end{array}$ & 6 & $\mathbf{F}$ & Do. \\
\hline
\end{tabular}

a S, simple crystal; G, group of crystals in nearly parallel position; T, twin erystal.

\section{AXIAL ELEMENTS.}

The discussion of the axial elements of ferberite leads at once to the question of the relation of ferberite to the wolframite group.

In this connection a consideration of the relation in angular values between the pure iron tungstate and the pure manganese tungstate is of interest. The ferberite crystals at hand did not yield results as satisfactory as had been expected, because of the imperfection of the crystals, due to striations, parallel groupings, and like features; because of the scarcity of well-developed terminal forms; and because the high polish of most of the crystals had been destroyed by the hydrofluoric acid used to remove the matrix and clean the crystals.

\section{CALCULATION OF VALUES.}

Below are given the best measurements obtained that are suitable for the calculation of the axial elements, and these are compared with the measurements given in the literature for the members of the 
wolframite group. All measurements were made with a Goldschmidt two-circle goniometer.

\section{Average of best measurements.}

(010) : (110)

Fair reflection:

$50^{\circ} 16^{\prime}$

22
23
12
24
20
22
16
15

Poor reflection:

$50^{\circ} 31^{\prime}$

27

28

22

17

20

21

Average of 9 measurements with fair reflection, $50^{\circ} 19^{\prime}$.

Average of 7 measurements with poor reflection, $50^{\circ} 24^{\prime}$.

Average of the 16 measurements, ${ }^{1}$ $50^{\circ} 20 \frac{1}{2}^{\prime}$.

(001) : (011)

Good reflection:

$\begin{array}{cc}41^{\circ} & 00^{\prime} \\ & 01 \\ & 00 \\ 40 & 59 \\ & 59 \\ & 57 \\ & 57 \\ & 57 \\ & 58 \\ & 56 \\ & 53 \\ & 56\end{array}$

Average of 11 measurements, $40^{\circ} 58^{\prime}$.
(010) : (210)

Good reflection:

$67^{\circ} 27^{\prime}$

23

24

26

25

31

25

32

21

Fair reflection:

$67^{\circ} 17^{\prime}$

23

16

28

19

27

30

26

Average of 9 measurements with good reflection, $67^{\circ} 26^{\prime}$.

Average of 8 measurements with fair reflection, $67^{\circ} 23^{\prime}$.

Average of the 17 measurements, ${ }^{1}$ $67^{\circ} 25^{\prime}$.

$$
\text { (001) : (102) }
$$

$27^{\circ} 46^{\prime}$

49

$27 \quad 43$

45

37

50

Average of 6 measurements, $27^{\circ} 46^{\prime}$. (001) : (100)

$89^{\circ} 50^{\circ}$
34
32
33

Average of 4 measurements, $89^{\circ} 37^{\prime}$.

In the measurements of the prism angles the $\phi$ angle was obtained, this being the same as the angle (010) $\wedge$ prism. The $v_{0}$ or zero 
reading on $b(010)$ was averaged for each crystal from the readings obtained on (010) and $(0 \overline{1} 0)$ (often a cleavage face), and from the aver-

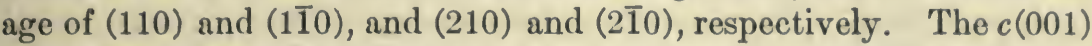
faces were generally striated in the zone (001): (100), but this in nowise interfered with the accuracy of the measurement of the angle (001): (011). The accurate measurements from (001) to (102) and to (100) were very few in number, as the base (001) was striated in this direction on most of the crystals.

\section{COMPARISON OF VALUES.}

Instead of deriving axial elements from these angular values I have compared the interfacial angles directly with the best ones I could find in the literature for the entire wolframite group. These have been arranged in order of decreasing percentage of $\mathrm{MnO}$, so that the first lines in the table below represent hübnerite and the last lines (except the very last) represent ferberite. The very last line contains the values taken from Goldschmidt's Winkeltabellen, in which the axial elements of Descloizeaux, Krenner, and Seligmann have been averaged. (See Bibliography, pp. 74-75.) A careful study of the angular values given in any column does not show any regular increase or decrease corresponding with the regular decrease in percentage of $\mathrm{MnO}$. In fact the variation in angular values for two or more wolframites of nearly the same composition is nearly as great as between the extreme end members. The correlation of the chemical composition and the crystallographic constants is doubtful in so far as the analytical figures given were not obtained on the material actually measured.

Comparison of angles with variation in chemical composition.

\begin{tabular}{|c|c|c|c|c|c|c|c|}
\hline \multirow{2}{*}{$\begin{array}{l}\text { Locality and } \\
\text { material. }\end{array}$} & \multirow{2}{*}{ Author. } & \multirow{2}{*}{$\begin{array}{l}\text { Per } \\
\text { cent } \\
\text { MnO. }\end{array}$} & \multicolumn{3}{|r|}{ Angle. } & \multicolumn{2}{|l|}{$=$} \\
\hline & & & (010):(110). & $(010):(210)$ & $(001):(011)$ & $(001):(102)$ & $(001):(100)$ \\
\hline $\begin{array}{c}\mathrm{MnWO}_{\text {ficial). }} \text { (arti- } \\
\text {. }\end{array}$ & $\begin{array}{l}\text { Groth and Arz- } \\
\text { runi. }\end{array}$ & 23.4 & $\stackrel{\circ}{ } \quad \dot{15}$ & - , & 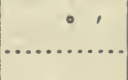 & - , & •. \\
\hline $\begin{array}{l}\text { Megabasite ..... } \\
\text { Colorado........ }\end{array}$ & Penfield........................... & $\begin{array}{l}22.24 \\
21.93\end{array}$ & $5027 \frac{1}{2}$ & 6719 & 4055 & $2712 \frac{1}{2}$ & $8907 \frac{1}{2}$ \\
\hline $\begin{array}{l}\mathrm{Mn}_{2} \mathrm{Fe}_{3}\left(\mathrm{WOO}_{4}\right)_{5} \\
\text { (artificial). }\end{array}$ & $\begin{array}{l}\text { Groth and Arz } \\
\text { runi. }\end{array}$ & 9.4 & 5021 & -. & $4051 \frac{1}{2}$ & & \\
\hline Saxony......... & Krenner.......... & 4.96 & 5030 & 6736 & 40423 & 2729 & $\begin{array}{r}89391 \\
\end{array}$ \\
\hline 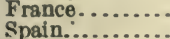 & Descloizeaux.... & $\begin{array}{l}4.84 \\
3.15\end{array}$ & $\begin{array}{l}5018 \frac{1}{2} \\
5036\end{array}$ & $\begin{array}{l}6728 \\
6740\end{array}$ & $\begin{array}{ll}40 & 57 \\
41 & 031\end{array}$ & $\begin{array}{l}2727 \frac{1}{3} \\
2750 \frac{1}{4}\end{array}$ & $\begin{array}{l}8921 \frac{1}{2} \\
8934\end{array}$ \\
\hline Colorado .......... & W.T. Schalier.. & .1 & 50204 & $67 \cdot 25$ & 4058 & 2746 & $\begin{array}{l}8934 \\
8937\end{array}$ \\
\hline $\mathrm{FeWO}_{4}$ (arti- & Groth and Arz- & .0 & 5033 & ........ & .......... & 2733 & -. \\
\hline Average a.. & $\begin{array}{l}\text { Goldschmidt's } \\
\text { Winkeltab e l- } \\
\text { len. }\end{array}$ & & 5027 & $6734 \frac{1}{3}$ & 4054 & 2735 & 8932 \\
\hline
\end{tabular}


A definite, measured difference in crystallographic constants between ferberite $\left(\mathrm{FeWO}_{4}\right)$ and hübnerite $\left(\mathrm{MnO}_{4}\right)$ is not shown by the table just given. The average axial elements given by Goldschmidt represent closely the angular values for the different members of the wolframite group. These values are also close to those obtained on the Colorado ferberite as shown below.

Comparison of angles of ferberite from Colorado with the values given in Goldschmidt's Tables.

\begin{tabular}{|c|c|c|c|}
\hline Angle. & $\begin{array}{l}\text { Gold- } \\
\text { schmidt's } \\
\text { Winkel- } \\
\text { tabellen. }\end{array}$ & $\begin{array}{c}\text { Boulder } \\
\text { County } \\
\text { ferberite. }\end{array}$ & Difference. \\
\hline $\begin{array}{l}(010):(110) \ldots \ldots \\
(010):(210) \ldots \ldots \ldots \\
(001):(011) \ldots \ldots \ldots \\
(001):(102) \ldots \ldots \ldots \\
(001):(100) \ldots \ldots \ldots\end{array}$ & $\begin{array}{cc}\circ & , \\
50 & 27 \\
67 & 34 \\
40 & 54 \\
27 & 35 \\
89 & 32\end{array}$ & \begin{tabular}{ll}
$\circ$ & \multicolumn{1}{c}{} \\
50 & 201 \\
67 & 25 \\
40 & 58 \\
27 & 46 \\
89 & 37
\end{tabular} & $\begin{array}{l} \\
-061 \\
-09 \\
+04 \\
+11 \\
+05\end{array}$ \\
\hline
\end{tabular}

The axial elements given by Goldschmidt, namely, $a: b: c=0.8255$ : $1: 0.8664, \beta=89^{\circ} 32^{\prime}$, therefore best represent the constants for the entire wolframite group.

The data for the percentages of manganese given in the table on page 45 have been taken from Dana. ${ }^{1}$ Descloizeaux's measurements were made on material from Vilate, near Chanteloube (HauteVienne), France. An analysis of wolframite from Chanteloube shows 4.84 per cent $\mathrm{MnO}$ and 19.32 per cent $\mathrm{FeO}$. Krenner's measurements were made on crystals from Ehrenfriedersdorf, Saxony, and an analysis of material from the same locality shows 4.96 per cent $\mathrm{MnO}$ and 19.16 per cent FeO. Seligmann's ferberite from Sierra Almagrera, Spain, contains 3.15 per cent $\mathrm{MnO}$ and 19.95 per cent $\mathrm{FeO}$, according to Doelter. ${ }^{2}$ Two confirmatory analyses of the Spanish ferberite show 3.00 and 3.02 per cent $\mathrm{MnO}$ with high $\mathrm{FeO}$. Hübnerite from Colorado $^{3}$ showed 21.93 per cent $\mathrm{MnO}$ and 2.91 per cent $\mathrm{FeO}$. "Megabasite" from Schlaggenwald contained 22.24 per cent $\mathrm{MnO}$ and 3.74 per cent $\mathrm{FeO}$.

\section{FORMS AND ANGTES.}

A total of 32 forms were determined on the ferberite crystals from Colorado. Of these 12 are new for the wolframite group. These 32 forms are given in the table below with the measured and calculated coordinate angles. The new forms are marked with an asterisk (*). 
List of forms and angles on ferberite crystals.

[New forms are marked with an asterisk.]

\begin{tabular}{|c|c|c|c|c|c|c|c|}
\hline \multirow{2}{*}{ No. } & \multirow{2}{*}{ Letter. } & \multicolumn{2}{|c|}{ Symbol. } & \multicolumn{2}{|c|}{ Measured. } & \multicolumn{2}{|c|}{ Calculated. } \\
\hline & & $\begin{array}{l}\text { Gold- } \\
\text { schmidt. }\end{array}$ & Miller. & $\phi$ & $\rho$ & $\phi$ & $\rho$ \\
\hline & & & & - 1 & - 1 & - & - 1 \\
\hline 1 & $c$ & 0 & 001 & 9000 & 023 & 9000 & 028 \\
\hline 2 & $b$ & $0 \infty$ & 010 & 000 & 9000 & 000 & 9000 \\
\hline 3 & $a$ & $\infty 0$ & 100 & 9012 & 9000 & 9000 & 9000 \\
\hline 4 & $r$ & $\infty 2$ & 120 & 3349 & 9000 & 3112 & 9000 \\
\hline 5 & $m$ & $\infty$ & 110 & 5021 & 9000 & 5027 & 9000 \\
\hline 6 & $l$ & $2 \infty$ & 210 & 6725 & 9000 & 6731 & 9000 \\
\hline 7 & $* R$ & $4 \infty$ & 15.7 .0 & 6900 & 9000 & 6856 & 9000 \\
\hline 8 & $* C$ & $+\infty$ & 940 & 7001 & 9000 & 6951 & 9000 \\
\hline 9 & $* F$ & $\infty$ & 520 & 7139 & 9000 & 7144 & 9000 \\
\hline 10 & $Q$ & $\frac{2}{3} \infty$ & 830 & 7319 & 9000 & 7248 & 9000 \\
\hline 11 & $d$ & $3 \infty$ & 310 & $74 \quad 47$ & 9000 & 7437 & 9000 \\
\hline 12 & ${ }^{*} G$ & $\infty$ & 720 & 7645 & 9000 & 7644 & 9000 \\
\hline 13 & $* M$ & $5 \infty$ & 510 & 8030 & 9000 & 8038 & 9000 \\
\hline 14 & $* N$ & $4 \infty$ & 11.2 .0 & 8135 & 9000 & $\delta 128$ & 9000 \\
\hline 15 & $\vec{j}$ & $6 \infty$ & 610 & 8200 & 9000 & 8210 & 9000 \\
\hline 16 & $* L$ & $7 \infty$ & 710 & 8308 & 9000 & 8316 & 9000 \\
\hline 17 & $\bar{n}$ & $8 \infty$ & 810 & 8420 & 9000 & 8406 & 9000 \\
\hline 18 & $f$ & 01 & 011 & 004 & 4054 & 032 & 4054 \\
\hline 19 & $u$ & +10 & 104 & 9000 & 1628 & 9000 & 1508 \\
\hline 20 & $t$ & +20 & 102 & 9000 & 2746 & 9000 & 2803 \\
\hline 21 & $* H I$ & +0 & 904 & 9000 & 6631 & 9000 & 6707 \\
\hline 22 & $r$ & - iो 0 & I. 0.11 & 9000 & 420 & 9000 & 459 \\
\hline 23 & $* B$ & $+\frac{3}{3}$ & 123 & 3110 & 3413 & 3147 & 3412 \\
\hline 24 & $* E$ & + $151^{\circ}$ & 5.9 .14 & 3425 & 3348 & 3431 & 3103 \\
\hline 25 & $\omega$ & +1 & 111 & 5025 & 5345 & 5040 & 5349 \\
\hline 26 & $\Delta$ & $+\frac{1}{2}$ & 112 & $50 \quad 16$ & 3424 & $50 \quad 53$ & 3429 \\
\hline 27 & $* A$ & $+\frac{3}{1}$ & 337 & 5045 & 3037 & 5058 & 3031 \\
\hline 28 & $p$ & $+\frac{1}{2}+$ & 214 & 6942 & 3122 & 6753 & 2955 \\
\hline 29 & $* D$ & $+1 \frac{1}{3}$ & 313 & 7421 & 4721 & $74 \quad 44$ & 4738 \\
\hline 30 & 8 & -12 & โิ21 & 3914 & 6345 & 3100 & 6341 \\
\hline 31 & $e$ & $-\frac{1}{2}$ & I12 & 5016 & 3427 & $\begin{array}{lll}50 & 01\end{array}$ & 3359 \\
\hline 32 & 0 & -1 & I11 & $50 \quad 26$ & 5348 & 5014 & 5334 \\
\hline
\end{tabular}

\section{NEW FORMS.}

A somewhat detailed description is given of the new forms found on the crystals. They may be grouped as follows:

Groups of new forms on ferberite crystals.

New prisms.................... 7

New positive domes................ 1

New positive pyramids................ 4

Measurements of ${ }^{*} R\{15.7 .0\}$.

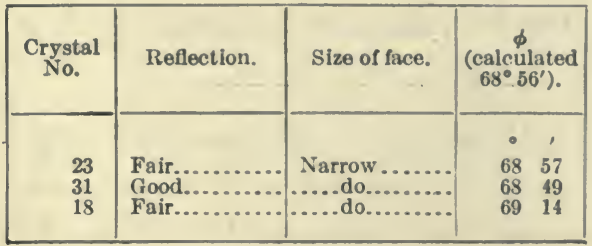


On crystal 23 , the new form, $R$, lies between $l\{210\}$ and $Q\{830\}$ as a very narrow face, giving a distinct signal. The faces measured in one-half the prism zone are (010), (110), (210), (810), (100); (010), (110), (210), (15.7.0), ( $\overline{8} 30)$, (100).

On crystal 31, three faces lying very close together gave good signals, and the measurements showed the presence of the three forms $l\{210\}, R\{15.7 .0\}$, and $C\{940\}$.

On crystal 18 a part of the prism zone (see description of $C\{940\}$, crystal 18) showed the forms $Q\{830\}, C\{940\}, R\{15.7 .0\}$, and $l\{210\}$.

In all the three occurrences of $R\{15.7 .0\}$ the form is associated with $l\{210\}$ and in two of them it lies between $l\{210\}$ and $C\{940\}$. From these facts, as well as the close agreement in measured and calculated values, the form is considered as definite and well established.

Measurements of ${ }^{*} C\{940\}$.

\begin{tabular}{|c|c|c|c|}
\hline $\begin{array}{c}\text { Crystal } \\
\text { No. }\end{array}$ & Reflection. & Size of face. & $\begin{array}{c}\phi \\
\text { (calculated } \\
\left.69^{\circ} 51^{\prime}\right) .\end{array}$ \\
\hline $\begin{array}{r}18 \\
31 \\
1\end{array}$ & $\begin{array}{l}\text { Fair..... } \\
\text { Good.... } \\
\text { Poor... }\end{array}$ & $\begin{array}{l}\text { Narrow ...... } \\
\text { Li...do........... }\end{array}$ & $\begin{array}{cc}\circ & , \\
69 & 49 \\
69 & 53 \\
70 & 21\end{array}$ \\
\hline
\end{tabular}

On crystal 18 the form was one of three faces lying close to $l\{210\}$ and between it and $a\{100\}$. They form alternating narrow faces, but the signals they gave were clear and distinct. The faces were not striated. The prism zone is incomplete, the piece measured being only a fragment of a crystal. The other three forms present in the zone are $Q\{830\}, R\{15.7 .0\}$, and $l\{210\}$.

On crystal 31 the three forms $l\{210\}, R\{15.7 .0\}$, and $C\{940\}$ lie close together and form alternating nonstriated faces similar to those observed on crystal 18. The other parts of the prism zone are not measurable, so that the presence on this crystal of other faces of the last two forms could not be confirmed.

On crystal 1 the form was noted once as a line face between $a(100)$ and a cleavage face of $b(0 \overline{1} 0)$. On other parts of the crystal the form was absent.

Measurements of ${ }^{*} F\{520\}$.

\begin{tabular}{|c|c|c|c|}
\hline $\begin{array}{l}\text { Crystal } \\
\text { No. }\end{array}$ & Reflection. & Size of face. & $\begin{array}{c}\phi \\
\text { (calculated } \\
\left.71^{\circ} 44^{\prime}\right):\end{array}$ \\
\hline $\begin{array}{r}1 \\
22\end{array}$ & Poor... & $\begin{array}{l}\text { Line face....... } \\
\ldots . . . \text { do } \ldots . . . .\end{array}$ & $\begin{array}{c}\circ \\
71 \\
71 \\
71\end{array}$ \\
\hline
\end{tabular}


On crystal 1 the new prism was noted once with the forms $a\{100\}$, $m\{110\}, b\{010\}$. On crystal 22 the portion of the zone with the new prism was richer in faces, chose present being $b(010), m(\overline{1} 10), l(210)$, $F(\overline{5} 20), a(\overline{1} 00)$. The new form $F$ is considered as established, though the agreement between the angles is not so good as for the two more complex symbols just described.

Measurement of ${ }^{*} G\{720\}$.

(calculated

$\left.76^{\circ} 44^{\prime}\right)$.

Crystal No. 14

$76^{\circ} 45^{\prime}$

The new prism $G$ was observed only once as a narrow face yielding a fair reflection. It formed one of four faces lying very close together, each of which, however, gave a distinct signal. These four faces, lying between $m(110)$ and $a(100)$, are $G(720)$, a face near (410) but not determinable, $M(510)$, and $N(11.2 .0)$.

Measurements of ${ }^{*} M\{510\}$.

\begin{tabular}{|c|c|c|c|}
\hline $\begin{array}{c}\text { Crystal } \\
\text { No. }\end{array}$ & Reflection. & Size of face. & $\begin{array}{c}\phi \\
\text { (calculated } \\
80^{\circ} 38^{\prime} \text { ). }\end{array}$ \\
\hline $\begin{array}{r}13 \\
1 \\
14\end{array}$ & $\begin{array}{l}\text { Good... } \\
\text { Poor... } \\
\text { Fair... }\end{array}$ & $\begin{array}{l}\text { Narrow } . . . . \\
\ldots . \text { do } \\
\ldots . . .\end{array}$ & $\begin{array}{ll}\circ & , \\
80 & 21 \\
80 & 58 \\
80 & 12\end{array}$ \\
\hline
\end{tabular}

The new prism $M$ is always associated with several other rare prisms. Narrow faces of it were found on crystal 13 with $n(810)$, $a(100), n(8 \overline{1} 0), M(5 \overline{1} 0)$; on crystal 1 as a striated face with $b(010)$, $m(110), F(520), a(100), M(5 \overline{1} 0), l(2 \overline{1} 0), m(1 \overline{1} 0)$, and $b(0 \overline{1} 0)$; and on crystal 14 with $G(720)$.

Measurements of ${ }^{*} N\{11.2 .0\}$.

\begin{tabular}{|c|c|c|c|}
\hline $\begin{array}{l}\text { Crystal } \\
\text { No. }\end{array}$ & Reflection. & Size of face. & $\begin{array}{l}\text { क } \\
\text { (calculated } \\
81^{\circ} 28^{\prime} \text { ). }\end{array}$ \\
\hline $\begin{array}{l}14 \\
14 \\
17\end{array}$ & 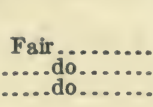 & 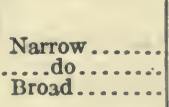 & $\begin{array}{ll}\circ & , \\
81 & 26 \\
81 & 31 \\
81 & 48\end{array}$ \\
\hline
\end{tabular}

The two faces of $N$ on crystal 14 are both narrow and both occurred with other prisms, but each with different forms. With one of them the associated forms were $m(\overline{1} 10), G(\overline{7} 20)$, a face near $(410), M(\overline{5} 10)$, $N(11.2 .0)$ and $a(100)$; with the other the forms were $n(\overline{81} 0), L(\overline{71} 0)$, and $N(11 . \overline{2} .0)$. On crystal $17 N$ occurred with $a(100), n(810)$, and $l(210)$, being broader than either $l$ or $n$.

$35659^{\circ}-$ Bull. $583-14-4$ 
Measurements of $* L\{710\}$.

\begin{tabular}{|c|c|c|c|}
\hline $\begin{array}{c}\text { Crystal } \\
\text { No. }\end{array}$ & Reflection. & Size of face. & $\begin{array}{c}\phi \\
\text { (calculated } \\
83^{\circ} 16^{\prime} \text { ). }\end{array}$ \\
\hline $\begin{array}{r}14 \\
5 \\
5\end{array}$ & $\begin{array}{l}\text { Fair } . . . . \\
\text { Poor } . . . \\
\text { Fair.............. }\end{array}$ & $\begin{array}{l}\text { Narrow ........ } \\
\text { Broad......... } \\
\ldots \ldots . \text { do } . . . . .\end{array}$ & $\begin{array}{cc}\circ & , \\
83 & 19 \\
83 & 11 \\
82 & 55\end{array}$ \\
\hline
\end{tabular}

The occurrence of $L\{710\}$ on crystal 14 has already been noted under $N\{11.2 .0\}$. On crystal 5 it is present twice as broad faces, in each case unaccompanied by other rare prisms and forming the only face between $a(100)$ and $l(210)$.

Measurements of ${ }^{*} H\{904\}$.

\begin{tabular}{|c|c|c|c|}
\hline $\begin{array}{c}\text { Crystal } \\
\text { No. }\end{array}$ & Reflection. & Size of face. & $\begin{array}{c}\text { (calculated } \\
\left.67^{\circ} 07^{\prime}\right) .\end{array}$ \\
\hline $\begin{array}{l}13 \\
14 \\
24 \\
15 \\
16 \\
19 \\
28 \\
31 \\
26 \\
34 \\
20 \\
27\end{array}$ & 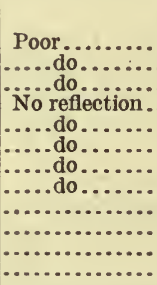 & 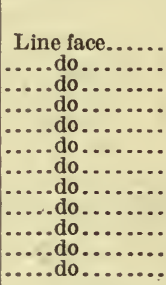 & $\begin{array}{c}\text {. } \\
6706 \\
6713 \\
6738 \\
a 66 \\
a 67 \\
a 66 \\
a 69 \\
a 68 \\
(b) \\
(b) \\
(b) \\
(b)\end{array}$ \\
\hline
\end{tabular}

a Approximate.

$b$ Not measured.

This new dome, always present as a line face, was noted on 12 crystals, as shown in the table. The reflections from the faces were either very poor or not discernible, so that the approximate measurements (expressed only in degrees) were made by using the position of maximum illumination. The form is near to the simpler one $\{201\}$, but the measurements show that $\{904\}$ are the correct symbols. The calculated $\rho$ angle for the form $\{201\}$ is $64^{\circ} 37^{\prime}$ :

Figures 25, 26, 29, 30, 33, and 34 show the new form $H\{904\}$.

Measurements of ${ }^{*} B\{123\}$.

\begin{tabular}{|c|c|c|c|c|}
\hline $\begin{array}{c}\text { Crystal } \\
\text { No. }\end{array}$ & Reflection. & Size of face. & $\begin{array}{c}\dot{\phi} \\
\text { (calculated } \\
\left.31^{\circ} 47^{\prime}\right)\end{array}$ & $\begin{array}{l}\stackrel{\rho}{ } \\
\text { (calculated } \\
\left.34^{\circ} 1^{\prime}\right) \text {. }\end{array}$ \\
\hline $\begin{array}{l}13 \\
19\end{array}$ & $\begin{array}{l}\text { Poor............. } \\
\text {.....do......... }\end{array}$ & $\begin{array}{l}\text { Small .......... } \\
\text { Line face.... }\end{array}$ & $\begin{array}{cc}\circ & , \\
31 & 22 \\
30 & 58\end{array}$ & $\begin{array}{cc}\circ & 1 \\
34 & 21 \\
34 & 05\end{array}$ \\
\hline
\end{tabular}

On crystal 13 the small face of $B$ gave a poor but distinct reflection. The occurrence is illustrated in figure 25 (p. 66), an ideal representa- 
tion of the crystal, which shows two faces of the form. The second side of the crystal is, however, not present, as a cleavage face of (0I0) terminates that side of the crystal. On crystal 19 the form $B\{123\}$ is represented by a line face lying between $E\{5.9 .14\}$ and $f\{011\}$, both of which are larger than $B$. This occurrence is represented in figure 29 (p. 67). The form is probably also present on crystal 20, where a nonmeasurable line face was observed between $\Delta\{112\}$ and $f\{011\}$, though it could not be determined whether the form was $\{123\}$ or $\{5.9 .14\}$.

Measurements of ${ }^{*} E\{5.9 .14\}$.

\begin{tabular}{|c|c|c|c|c|}
\hline $\begin{array}{l}\text { Crystal } \\
\text { No. }\end{array}$ & Reflection. & Size of face. & $\begin{array}{c}\phi \\
\text { (calculated } \\
\left.34^{\circ} 31^{\prime}\right) \text {. }\end{array}$ & $\begin{array}{l}\text { (calcúlated } \\
34^{\circ} 03^{\prime} \text { ). }\end{array}$ \\
\hline $\begin{array}{l}19 \\
20 \\
27\end{array}$ & $\begin{array}{l}\text { Poor.... } \\
\text { …..do. } \\
\text { …do. }\end{array}$ & 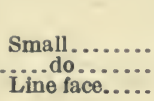 & 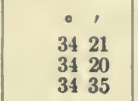 & $\begin{array}{cc}\circ & \text { ' } \\
33 & 50 \\
34 & 02 \\
33 & 31\end{array}$ \\
\hline
\end{tabular}

The first two occurrences of $E\{5.9 .14\}$ are small faces, much wider than the usual line faces and, as shown in figure 29 (p. 67), the face on crystal 19 reaches a fair size, whereas the corresponding simpler form $B\{123\}$ is present as a line face. On crystal 20 (fig. 30, p. 68) the small face of $E\{5.9 .14\}$ lies between $\Delta\{112\}$ and $f\{011\}$ and also attains an appreciable size. On crystal 27 , however, it is present as a mere line face.

The symbols for the form $E$ are rather complex and unusual, but the identification of the form on three crystals, the small distinct faces, and the close agreement between measured and calculated angles show that the form is well established.

Measurements of ${ }^{*} A\{337\}$.

\begin{tabular}{|c|c|c|c|c|}
\hline $\begin{array}{c}\text { Crystal } \\
\text { No. }\end{array}$ & Reflection. & Size of face. & $\begin{array}{c}\phi \\
\text { (calculated } \\
\left.50^{\circ} 58^{\prime}\right) .\end{array}$ & $\begin{array}{l}\text { p } \\
\text { (calculated } \\
30^{\circ} 31^{\prime} \text { ). }\end{array}$ \\
\hline $\begin{array}{l}13 \\
15 \\
20 \\
21\end{array}$ & $\begin{array}{l}\text { Poor... } \\
\ldots . . \text { do } \\
\ldots . . \text { do } \\
\text {......do. }\end{array}$ & 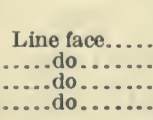 & $\begin{array}{lc}\circ & , \\
50 & 47 \\
51 & 00 \\
51 & 00 \\
50 & 13\end{array}$ & $\begin{array}{cc}\circ & , \\
31 & 08 \\
30 & 12 \\
30 & 05 \\
31 & 03\end{array}$ \\
\hline
\end{tabular}

The form $A$ is characteristically a line face between $c\{001\}$ and $\Delta\{112\}$. The only forms in this zone observed on these crystals are $m\{110\}, \omega\{111\}, \Delta\{112\}, A\{337\}, c\{001\}, e\{\overline{1} 12\}$, and $o\{\overline{1} 11\}$. The form is shown in figures 25 and 30 (pp. 66, 68).

$* D\{313\}$. Only one face of this new form was observed, this being on crystal 19, where a small face yielded a fair reflection whose measurement gave $\phi, 74^{\circ} 21^{\prime}$ (calculated $74^{\circ} 44^{\prime}$ ); $\rho, 47^{\circ} 21^{\prime}$ (calculated $47^{\circ} 38^{\prime}$ ). The form is shown in figure 29 (p. 67). 


\section{FORMS PREVIOUSLY DESCRIBED.}

\section{COMMMON FORMS.}

The common forms merit only a brief description, as their relative development and occurrence can well be seen by studying the drawings illustrating the different combinations and habits.

In the prism zone the orthopinacoid $a\{100\}$ is always strongly striated vertically. These striations are not shown in the crystal drawings. The orthopinacoid is often replaced by vicinal forms several degrees from the true position of $a\{100\}$. On other crystals the faces of $a\{100\}$ are very close to their true position of $90^{\circ} 00^{\prime}$. No connection could be traced between the presence of vicinal forms replacing $a\{100\}$ and the presence of new or rare prisms, as the following table shows:

Measurements of a $\{100\}$ and list of associated prisms.

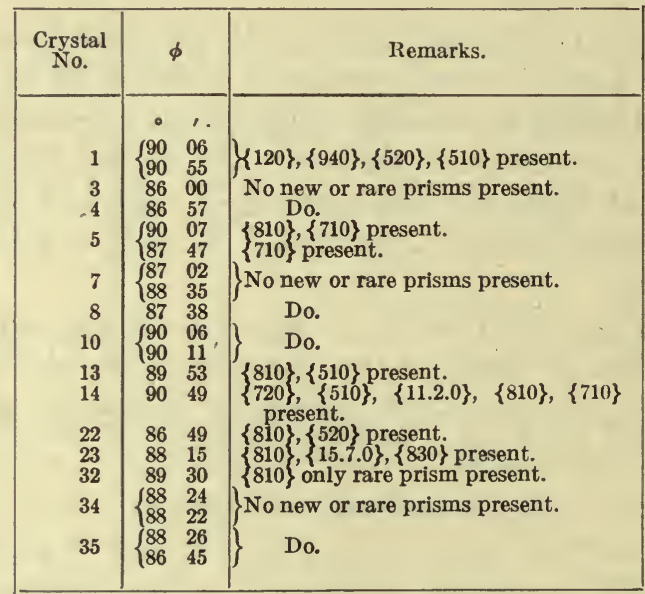

The common prisms $l\{210\}$ and $m\{110\}$ are striated on some crystals and free from any striæ on others, those without striæ yielding good and distinct reflections.

The base $c\{001\}$ is generally rounded in the zone $\{001\}:\{100\}$, commonly giving several reflections, the extreme ones on some crystals being several degrees apart.

The faces of $f\{011\}$, generally small, all gave good and distinct signals; those of $t\{102\}$ were generally distinct, although on a few crystals they were somewhat blurred.

The pyramids are generally so small that the reflections from their faces are faint. The striations on $\Delta\{112\}$ cause the large faces of this form to yield indistinct and blurred signals. The striations are shown in figure 28 (p. 67). 


\section{RARE FORMS.}

A number of rare forms which were observed on these crystals are entitled to a short discussion. The results are also applied to the tabulation of the forms of the wolframite group as developed on a later page.

$r\{120\}$, already noted by Descloizeaux and Jeremejew, ${ }^{1}$ is probably present as a line face on crystal $1 ; \phi$ measured $33^{\circ} 49^{\prime}$ (calculated $\left.31^{\circ} 12^{\prime}\right)$.

$Q\{\$ 30\}$, found by Penfield on hübnerite from Colorado, ${ }^{2}$ is verified by the presence of two line faces on the crystals herein described. On crystal 18 a line face yielded a fair reflection whose measurement gave $\phi$ a value of $73^{\circ} 06^{\prime}$ (calculated $72^{\circ} 48^{\prime}$ ); crystal 23 showed a very narrow face, the measurement of whose reflection gave $\phi$ a value of $73^{\circ} 32^{\prime}$ (calculated $72^{\circ} 48^{\prime}$ ). Penfield's ${ }^{2}$ letter $q$ was changed ${ }^{3}$ to $Q$, as $q$ had already been preempted by the form $\{103\}$. $d\{310\}$, noted by Krenner, Böggild, and as doubtfully present by Moses, was found once on crystal 9 as a very narrow face, giving a poor reflection. $\phi$ measured $74^{\circ} 47^{\prime}$ (calculated $74^{\circ} 37^{\prime}$ ). The occurrence is illustrated in figure 24 (p. 66).

$j\{610\}$ was first described by Böggild, who assigned to the new form the letter $p$. As this letter had been used by Moses to designate the form $\{214\}$, I have changed Böggild's $p$ to $j$, as here given. The form was noted once, on crystal 9 , as a medium-sized striated face; $\phi$ measured about $82^{\circ}$ (calculated $82^{\circ} 10^{\prime}$ ). The form is shown in figure 27 (p. 67).

$n\{810\}$, first noted by Groth and Arzruni, has been observed a number of times on these crystals. Some occurrences are shown in figures 22,25 , and 27 . The angles measured are as follows:

Measurements of $n\{810\}$.

\begin{tabular}{|c|c|c|c|}
\hline $\begin{array}{c}\text { Crystal } \\
\text { No. }\end{array}$ & Reflection. & Size of face. & $\begin{array}{c}\phi \\
\text { (calculated } \\
\left.84^{\circ} 06^{\prime}\right) \text {. }\end{array}$ \\
\hline $\begin{array}{r}5 \\
13 \\
14 \\
17 \\
32\end{array}$ & 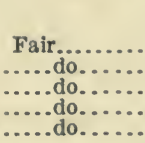 & 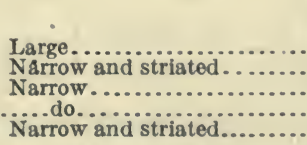 & $\begin{array}{rr}\circ & , \\
84 & 13 \\
83 & 50 \\
84 & 23 \\
84 & 52 \\
84 & 20\end{array}$ \\
\hline
\end{tabular}

$u\{104\}$, observed only by Jeremejew, is confirmed by finding it on crystal 13 as a line face with $t(102)$ and $H(904)$, as shown in figure 25 (p. 66). The reflection was very poor and its measurement gave $\rho$ $16^{\circ} 2 S^{\prime}$ (calculated $15^{\circ} 08^{\prime}$ ).

3 Goldschmidt's Winkeltabellen, p. 366, 1897. 
$r\{\overline{1} \cdot 0.11\}$, the only negative dome observed on any of these crystals, was first noted by Groth and Arzruni and is verified by finding it on three of these crystals. The reflections were, however, very poor, owing to the rounded and striated character of the faces. For comparison the original measurement of Groth and Arzruni is added to the table below. The $\rho$ angle, as here given, is equal to $(001 \wedge \overline{1} .0 .11)-$ $\left(90^{\circ}-\beta\right)\left[\begin{array}{ll}=0^{\circ} & 28^{\prime}\end{array}\right]$. The calculated values of $\rho$ for $\{1 \cdot 0.10\}$ and $\{1.0 .12\}$ are also added, and though my own measurements would agree better with these two forms, it is preferable, on account of the poor quality of the reflections, to assign them to the known form $r\{1.0 .11\}$.

Measurements of $\gamma\{\overline{1} \cdot 0.11\}$.

\begin{tabular}{|c|c|c|c|}
\hline $\begin{array}{c}\text { Crystal } \\
\text { No. }\end{array}$ & Reflection. & Size of face. & $\begin{array}{c}\stackrel{\rho}{\text { (calculated }} \\
\left.4^{\circ} 59^{\prime}\right) \text {. }\end{array}$ \\
\hline $\begin{array}{r}6 \\
9 \\
35\end{array}$ & 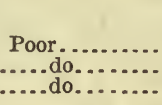 & 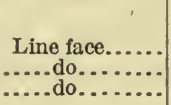 & $\begin{array}{lr}\circ & , \\
3 & 51 \\
5 & 23 \\
3 & 46\end{array}$ \\
\hline
\end{tabular}

As measured by Groth and Arzruni, $\rho=4^{\circ} 59 \frac{1}{2}^{\prime}$.

$\rho$ calculated for $\{\overline{1} .0 .10\}=5^{\circ} 32^{\prime}$.

$\rho$ calculated for $\{1.0 .12\}=4^{\circ} 32^{\prime}$.

The form $r\{1.0 .11\}$ is illustrated in figures 23 and 24 (p. 66).

$p\{214\}$ was first described by Moses on a crystal from Boulder County, Colo. It was also noticed by me as narrow faces on crystals 19, 29, and 30 (see figs. 19 and 29, pp. 64, 67), lying in the zone $c(001)$ : $l(210)$. The faces gave poor reflections. The angles measured by Moses are also shown in the table below.

The form was measured on crystal 19 with the following result:

Measurements of $p\{214\}$.

\begin{tabular}{|c|c|c|c|}
\hline \multirow{2}{*}{ Angle. } & \multirow{2}{*}{ Calculated. } & \multicolumn{2}{|c|}{ Measured. } \\
\hline & & Schaller. & Moses. \\
\hline $\begin{array}{l}\phi \ldots . . . . \\
\rho \ldots . . .\end{array}$ & \begin{tabular}{rr} 
& \multicolumn{1}{c}{} \\
6753 \\
2955
\end{tabular} & $\begin{array}{cc}\circ & \\
69 & 42 \\
31 & 22\end{array}$ & $\begin{array}{ll} & \\
68 & 45 \\
30 & 17\end{array}$ \\
\hline
\end{tabular}

In addition to the measurements of $p\{214\}$ given above, the form was identified on crystals 29 and 30 . These crystals, however, were so incompletely developed that they could not be well placed in polar position. The angle between $p(214)$ and $l(210)$ was therefore measured, with the following results:

Measurements of angle $p(214): l(210)$.

Crystal 29............................................. 38

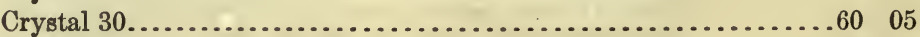

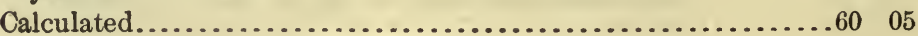


On all three of these crystals the form occurred in the zone $c(001)$ : $l(210)$, and on crystal 19 it was also determined to lie in the zone of and between $t(102)$ and $\Delta(112)$, so that its determination as (214) is verified by its zonal relations.

\section{DISCUSSION OF THE PRISM ZONE.}

The prism zone contains numerous forms of somewhat complex symbols and a discussion ${ }^{1}$ of these forms is here given in order to show how closely the forms approach the normal series.

The entire prism zone from $b(010)$ to $a(100)$ shows, when plotted in gnomonic projection (see fig. 35, p. 70), a partition into three parts, the points of division being $m(110)$ and $d(310)$. The three zone segments are then:

(1) $b(010), r(120), S(7.11 .0), m(110)$.

(2) $m(110), l(210), R(15.7 .0), C(940), F(520), Q(830), d(310)$.

(3) $d(310), G(720), M(510), N(11.2 .0), j(610), L(710), n(810), a(100)$.

In the following discussion, these three segments are taken up in turn:

(1) Zone segment, b.....m.

Form

$\left\{\begin{array}{cc}b & r \\ 010 & 120\end{array}\right.$

$S \quad m$

Sy

1

1-

0 .

ymbol $=\frac{h}{k}$

................................

$\frac{1}{2}$

$\frac{7}{11} \quad 1$

$-v^{\circ}$

$\mathrm{N}_{2}$

In place of $\frac{7}{4}$ or (7.11.0), the simple form 2 or (230) should occur.

The form $S(7.11 .0)$ was not observed by me but was described by Warren. The measured angle (7.11.0) : (7.11.0) is given as $74^{\circ} 51^{\prime}$, whereas the calculated angle $(230):(\overline{2} 30)$ is $77^{\circ} 50^{\prime}$, a difference too great to allow of the form being referred to the symbol (230). Compare also the remarks on page 69 on the indices of this form.

(2) Zone segment $m \ldots . . . d$.

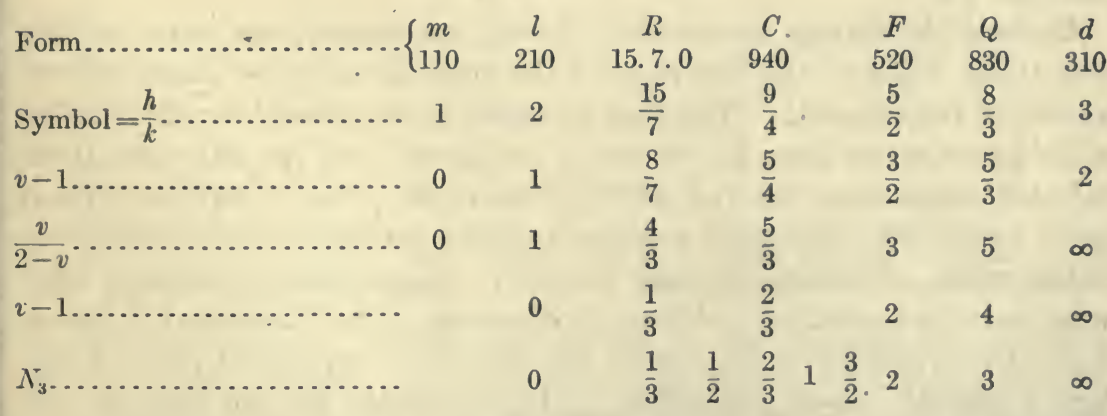

1 For a description of the methods of the discussion, see Hillebrand, W. F., and Schaller, W. T., The mercury minerals from Terlingua, Tex.: U. S. Geol. Survey Bull. 405, p. 13, 1909. 
The forms fit well into the normal series notwithstanding their complex indices.

(3) Zone segment $d \ldots . .$. .

\begin{tabular}{|c|c|c|c|c|c|c|c|c|}
\hline Form $\ldots \ldots \ldots \ldots \ldots \ldots \ldots \ldots \ldots$ & $\left\{\begin{array}{c}d \\
310\end{array}\right.$ & $\begin{array}{c}G \\
720\end{array}$ & $\begin{array}{r}M \\
510\end{array}$ & $\begin{array}{l}N . \\
11.2 .0\end{array}$ & $\begin{array}{l}\cdot j \\
610\end{array}$ & $\begin{array}{c}L \\
710\end{array}$ & $\begin{array}{c}n \\
810\end{array}$ & $\begin{array}{c}a \\
100\end{array}$ \\
\hline Symbol $=\frac{h}{k} \ldots \ldots \ldots \ldots \ldots \ldots \ldots$ & 3 & $\frac{7}{2}$ & 5 & $\frac{11}{2}$ & 6 & 7 & 8 & $\infty$ \\
\hline$\ldots \ldots \ldots$ & 0 & $\frac{1}{2}$ & 2 & $\frac{5}{2}$ & 3 & 4 & 5 & $\infty$ \\
\hline$v-2 \ldots \ldots \ldots \ldots \ldots \ldots \ldots \ldots \ldots \ldots \ldots$ & & & 0 & $\frac{1}{2}$ & 1 & 2 & 3 & $\infty$ \\
\hline 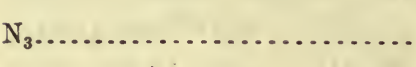 & & & 0 & $\frac{1}{3} \frac{1}{2}$ & 1 & 2 & & $\infty$ \\
\hline
\end{tabular}

All the new prisms fit well into the normal series.

\section{HABIT.}

Five very distinct habits were observed on the crystals examined, babit meaning the relative development and size of the different crystal faces and the consequent resultant shape of the crystal as a whole. Thus twin crystals are not considered as necessarily of different habit from a simple untwinned crystal. These fire habits are as follows:

1. Long, narrow, wedge-shaped. This is the habit most frequently observed for the ferberite crystals studied. This is the habit of the penetration twins (figs. 17 and 18, p.64) but not of the contact twins. (See Pls. VII and VIII, $A$, pp. 18, 19, and fig. 3.)

2. Short, prismatic, somewhat flattened parallel to the orthopinacoid $a\{100\}$. Crystals of this habit are fairly abundant. (See Pls. IX, p. 20, and X, p. 21, and fig. 4.)

3. Tabular, parallel to $a\{100\}$. Rarely observed in simple crystals but the common habit for the individuals of a contact twin. (See fig. 5, also the twin crystals shown in figs. 14 and 15, p. 63.)

4. Cubic rare. (See Pl. VIII, $B$, p. 19, and fig. 6.)

5. Rhombic, fairly abundant. (See Pls. XI, p. 22, and XII, p. 23, and fig. 7.)

Besides the habits mentioned above, two forms were noted which owe their shape to the cleavage of the crystals and are therefore not habits of the mineral. The first of these forms occurs in thin plates, which, as can be seen by reference to figure $8, A$ (p. 58), owe their tabular appearance to the $b\{010\}$ cleavage. The complete crystal from which this thin plate was cleaved was probably of the fourth or cubic habit. The second form occurs in long, slender rods and likewise owes its peculiarity of form to cleavage. As illustrated in figure $8, B$, it is probably derived from the edge of a crystal of habit 1 (see figs. 3 and 9 ), where the prism $l\{210\}$ extended to the edge of the crystal. 
Habit 1 . The wedge-shaped crystals are generally striated in the prism zone with the forms $a\{100\}, l\{210\}$, and $m\{110\}$ grading into one another, as shown in figure 9. On many crystals, however, the individual prism faces are sharply separated and commonly yield single

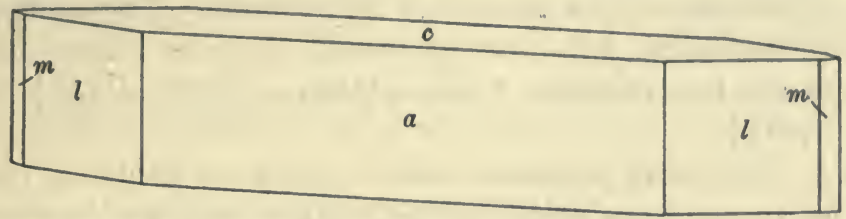

FIGURE 3.-Long, narrow, wedge-shaped crystal of habit 1, the most frequently observed habit. Forms: $c\{001\}, a\{100\}, m\{110\}, l\{210\}$.

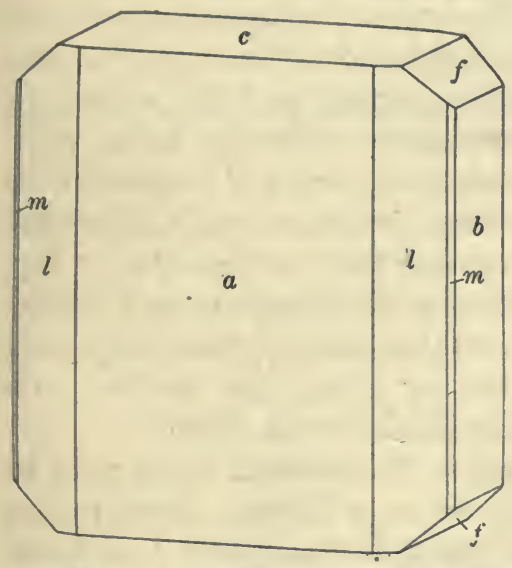

FIGURE 4. - Short, prismatic, somewhat flattened crystal of habit 2. Fairly abundant. Forms: $c\{001\}, b\{010\}, a\{100\}, m\{110\}, l\{210\}, f\{011\}$.

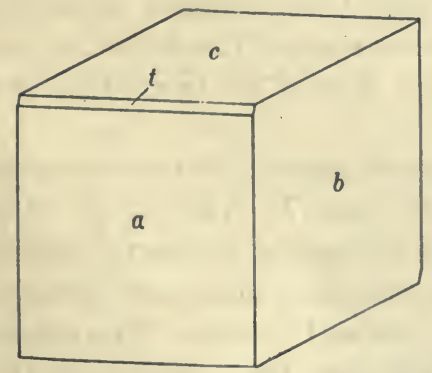

Figure 6.-Cubic crystal of habit 4. Rare. Forms: $c\{001\}, b\{010\}, a\{100\}, t\{102\}$.

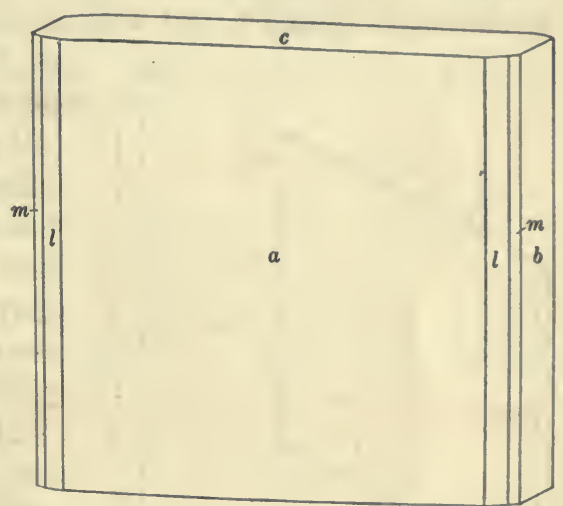

Figure 5.-Tabular crystal of habit 3. Common habit for contact twins, but rare for single crystals. Forms: $c\{001\}, b\{010\}, a\{100\}, m\{110\}$, $l\{210\}$.

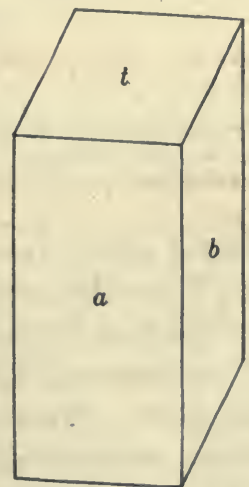

Figure 7.-Rhombic crystal of habit 5. Fairly abundant. Forms: $b\{010\}, a\{100\}, t\{102\}$.

distinct reflections. Figure 10 (crystal 4) also represents a typical crystal of this habit. On removing these crystals from the matrix, to which they are firmly attached, they usually cleave, and the resulting loosened crystal piece will consequently be much shorter in the 
direction of the $b$ axis than the original crystal. From the sharp edge on one side such cleaved pieces show a peculiar axlike shape. (See fig. 11, crystal2.) The penetration twins(figs. 17, 18, p. 64, and Pl.VIII, $A$, p. 19) are generally of this habit, and the contact twins (figs. 14 and 15, p. 63) are of the tabular or third habit. The wedge-shaped crystals of this first habit are generally poor in forms, few being found except the common ones, $a\{100\}, c\{001\}, l\{210\}, m\{110\}$, $b\{010\}, f\{011\}$.

Habit 2. The short prismatic habit, somewhat flattened parallel to $a\{100\}$, is the common habit for the wolframite group in general and is fairly abundant on the Colorado ferberite. An example was shown in figure 4 (crystal 1), and figure 12 illustrates the same combination as shown in figure 4 , but with a habit intermediate between the first

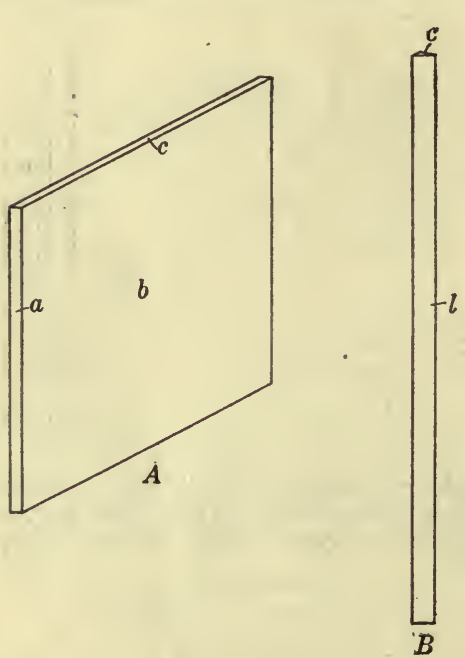

Figure 8.-Cleavage pieces of crystals. $A$, thin tabular; $B$, long, prismatic. Forms: $c\{001\}, b\{010\}$ cleavage, $a\{100\}, l\{210\}$. or wedge shaped and the second or short prismatic. The two habits show all gradations, and it is impossible to refer some crystals to one of these two habits rather than to the other. Figure 12 does not illustrate any particular crystal measured, but many were seen having about the relative proportions shown in the figure.

Habit 3. The tabular habit may be considered as a further development of the change from habit 1 to habit 2 , which is intermediate between habits 1 and 3 . Single crystals of this habit, as shown in figure 5, are rare, but in contact twins they are fairly abundant. The orthopinacoid, $a\{100\}$; is strongly striated in the twin crystals of this habit, whereas the other forms in the prism zone are in general nearly free of striæ.

Habit 4. The cubic crystals were found abundantly on one specimen, a side of which was literally covered with them (Pl. VIII, $B$, p. 19 , and fig. 6). They were small, few being over a millimeter in length, and were highlyiridescent. Some of the crystals are slightly elongated in the vertical direction, whereas others are nearly perfectly cubic. The shape of the crystals is conditioned by the combination being essentially that of the three pinacoids, $a\{100\}, b\{010\}, c\{001\}$, two of which are at right angles to each other, and the third very nearly so, the angle being $89^{\circ} 32^{\prime}$. The dome $t\{102\}$ is always present, and the pyramid $\Delta\{112\}$ is usually developed. The crystals of this habit are very poor in forms. 


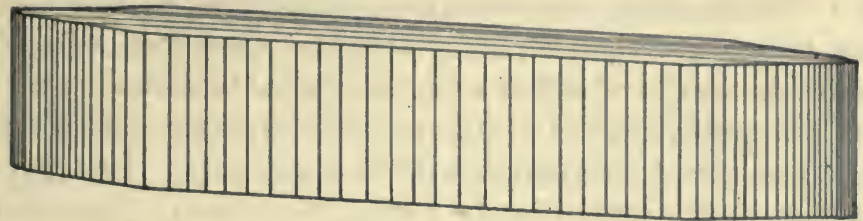

FIGURE 9. - Striations on wedge-shaped crystals of habit 1, causing a rounded appearance in the prism 2one. The top base is also slightly striated and in some crystals rounded.

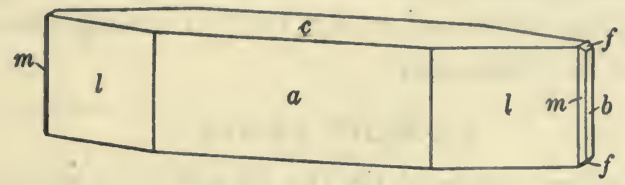

FIQURE 10.-Crystal 4, wedge-shaped habit, which has sharp, distinct faces, not rounded as in figure 9. Forms: $c\{001\}, b\{010\}, a\{100\}, m\{110\}, l\{210\}, f\{011\}$.

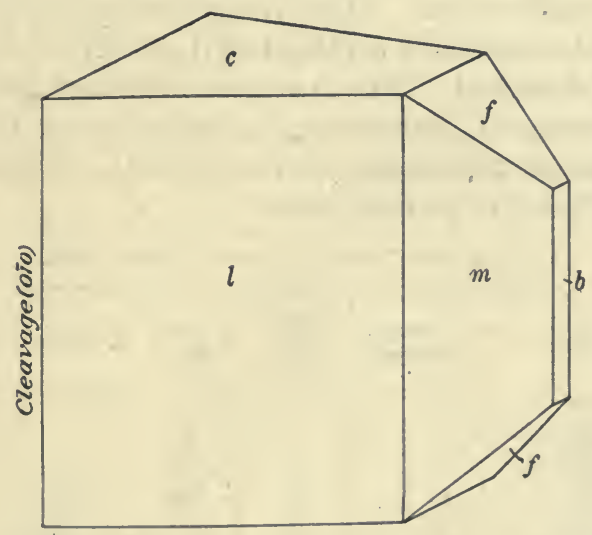

Fioure 11.-Peculiar shape of crystals of wedge-shaped habit caused by cleavage on $b\{010\}$. Crystal No. 2. Forms: $c\{001\}, b\{010\}, m\{110\}, l\{210\}, .\{011\}$.

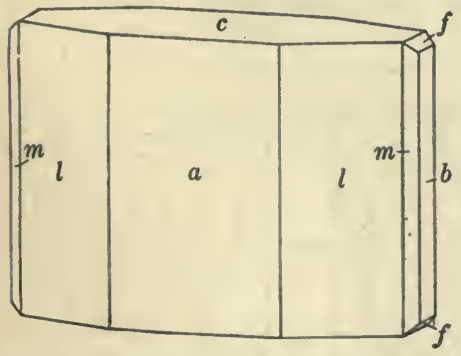

Figure 12.-Crystal of a short prismatic, somewhat flattened habit. Forms: $c\{001\}, b\{010\}, a\{100\}$, $m\{110\}, l\{210\}, f\{011\}$.

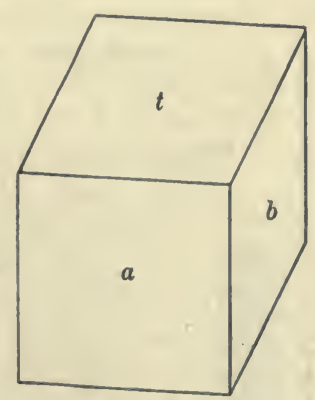

Figcre 13.-Crystal of rhombic habit, nearly equidimensional. Compare with figure 7, p. 57. Crystal No. 24. Forms: $b\{010\}, a\{100\}, t\{102\}$. 
Habit 5. The rhombic crystals are very abundant on some specimens and other habits are then entirely absent. (See Pls. XI and XII.) The rhomboids consist of either a single crystal bounded by plane surfaces or of an agglomeration of innumerable crystals, each deviating a little more from strict parallelism with the first unit. The crystals are generally elongated parallel to the $c$ axis, as shown in figure 7 , though some of them are more nearly equidimensional, as shown in figure 13 (crystal No. 24). The characteristic combination is $b\{010\}, a\{100\}$, $t\{102\}$, and other forms are rare. Many of these rhombic crystals are fairly large, the longer diameter of $t\{102\}$ in average individuals measuring nearly half a centimeter.

\section{COMBINATIONS.}

The combinations observed on the 38 crysta.s measured are shown in the following tables, wherein the different crystals have been grouped according to their habit, as the various habits have a markedly different combination. Thus the essential forms, that is, those which are characteristic for a certain habit, are given below for the five different habits observed. The forms are further grouped as prominent or not prominent, depending on whether or not they have a decided influence on the shape of the crystal. Forms that are not prominent are placed in parentheses.

Characteristic forms for each crystal habit.

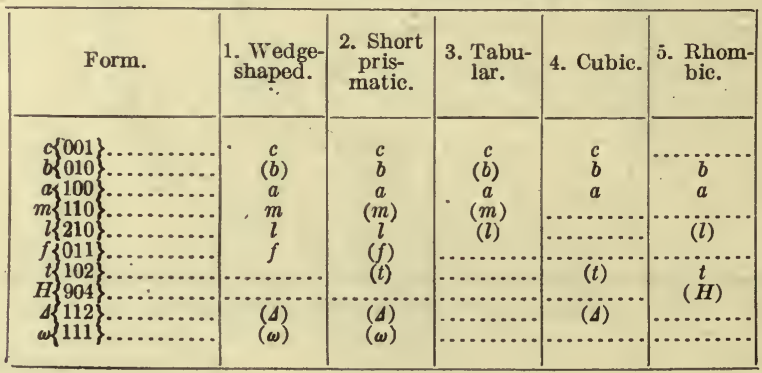

Combinations on crystals with wedge-shaped habit.

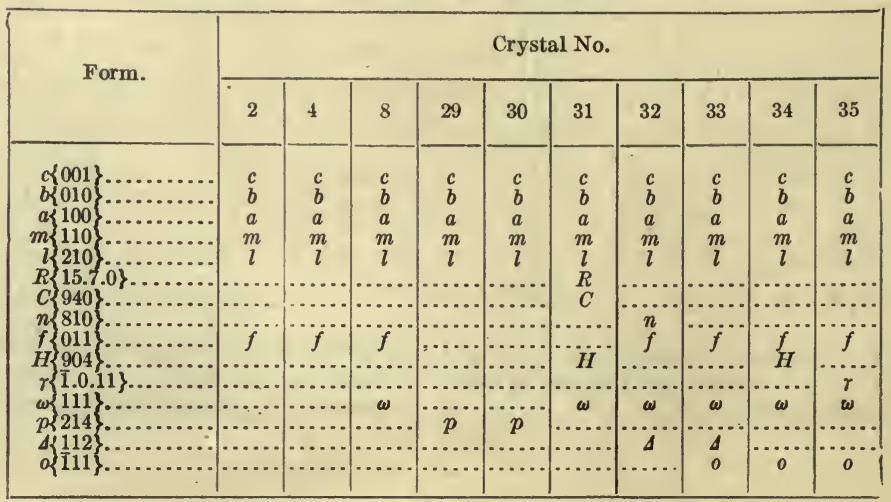


COMBINATIONS.

Combinations on crystals with short prismatic habit.

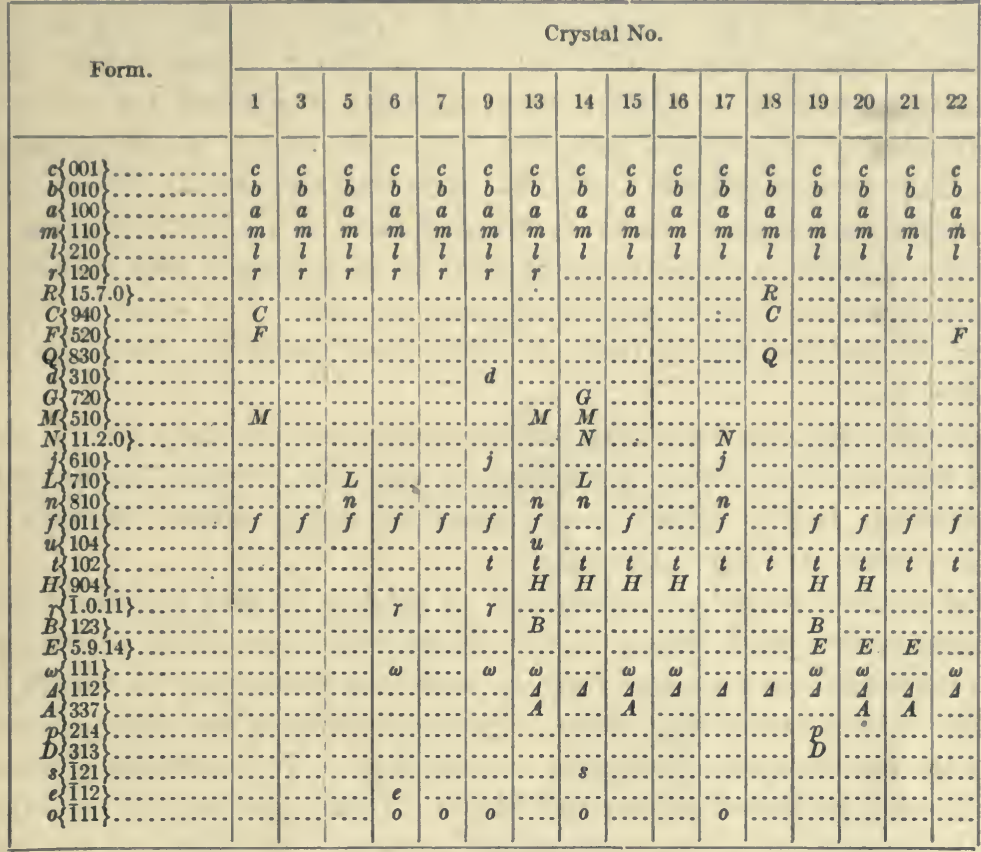

Combinations on crystals with tabular habit.

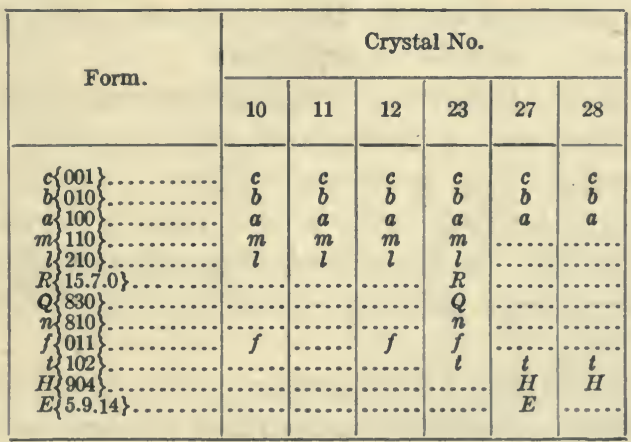

Combinations on crystals with cubic and rhombic habits.

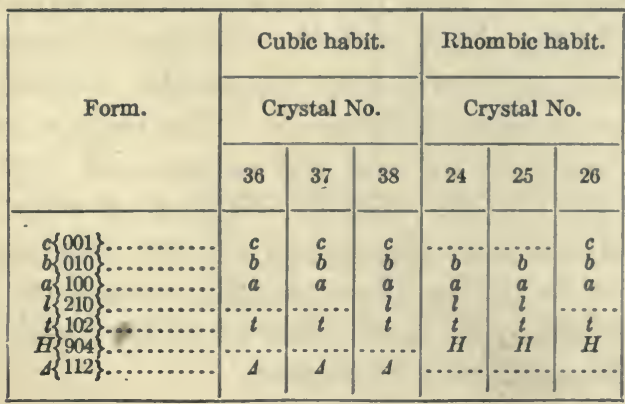




\section{TWINNING.}

Twin crystals were often observed. Only one twinning law was noticed, namely, with $\{023\}$ as the twinning plane. The many groupings parallel to $a\{100\}$ were carefully examined for evidences of twinning on the $a(100)$ face, but none were seen. As these parallel groupings generally have the $t(102)$ face well developed, twinning on the $a(100)$ face would cause a twinned face of $t(102)$ to assume the position of (102), and there would then be an apparent rear orthodome as well as a front one on such a twinned crystal. The absence of such a rear orthodome would indicate that these parallel groupings were not twinned.

Though only one twinning law was observed, namely $\{023\}$, there were two kinds of twins according to this law, namely, contact and penetration twins. Both were observed many times. though the contact twins are more abundant.

The contact twins are illustrated in figures 14 and 15, which show the twinned crystal facing in two directions, or in other words show the two positions a twinned group will take according to which face of $\{023\}$ acts as twinning plane. Both positions of the twinned group have the same crystallographic relationship. The position shown in figure 14 shows the clinopinacoid $b\{010\}$ of the twinned crystal adjoining the same form of the untwinned crystal. In figure 15 the basal pinacoid $c\{001\}$ of the twinned crystal is shown. In the two illustrations the relationships of the contact twins are more clearly indicated than can be done by a written description.

The line of contact of the two crystals affords some points of interest, but for the present only a description of it is given. Theoretically it should be a straight line, as drawn in figures 14 and 15 , but actually it is very uneven, the two parts of the twinned crystal being very irregularly dovetailed, as illustrated diagrammatically in figure 16, which was drawn from a twinned crystal (notebook No. A13), as seen on the goniometer.

In the penetration twins the containing unit is always much larger than the one which is partly embedded and projects out of the middle of the larger crystal, as shown in figure 17 . The two crystals, though of different appearance, have the same combination of crystal forms as those shown in figures 14 and 15. Similarly figure 18 shows the same kind of penetration twin with the smaller twinned crystal in the opposite direction to that in figure 17. The large untwinned crystal in figure 18 is shown with one end cleaved off, due to the clinopinacoidal cleavage $b(010)$. (See Pl. VIII, $A$, p. 19.)

The angle $c(001): \underline{b}(010)$ (fig. 17$)$ is $29^{\circ} 58^{\prime}$, and the angle $c(001)$ : $\underline{c}(001)$ (fig. 18) is $60^{\circ} 02^{\prime}$. These angular values are here given as reference will be made to them later and the position of the faces forming the angles can here well be seen. 
A peculiarity noted by Mr. Hess on several crystals similar to the one shown in figure 18 is that in front of the twinned crystal, on the larger untwinned unit, is a small cavity bounded by rough planeswhich

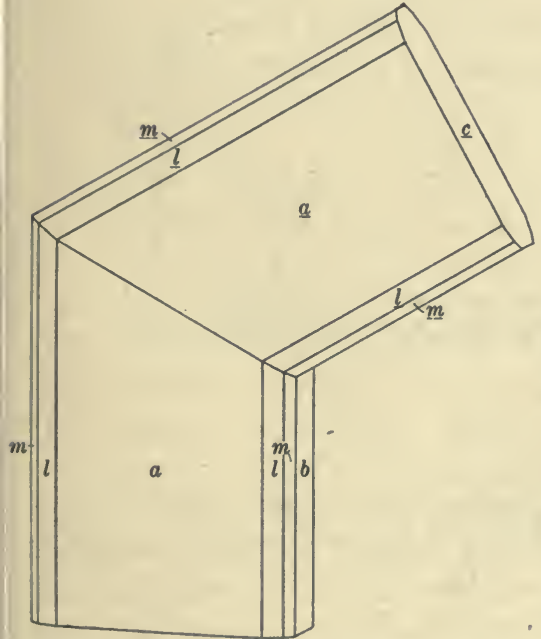

Figure 15.-Contact twin on (023). Forms: $c\{001\}, b\{010\}, a\{100\}, m\{110\}, l\{210\}$.

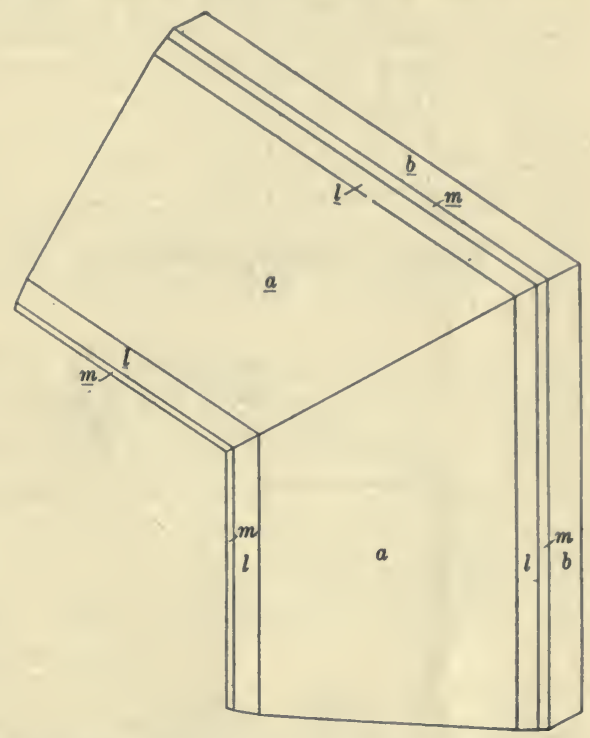

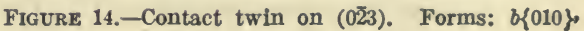
$a\{100\}, m\{110\}, l\{210\}$.

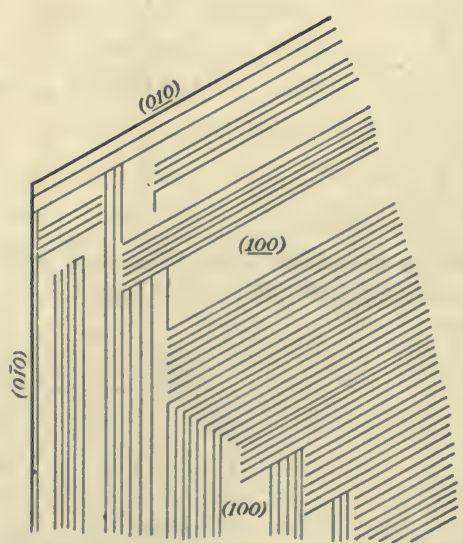

Fugure 16.- Line of contact of two contact twins.

however suggest that they may be slightly developed terminal faces, such as $f\{011\}$. (See Pl. VIII, $A$, p. 19, center.) They may be caused, however, by cryst,als of scheelite, now removed. 
64 COLORADO FERBERITE AND THE WOLFRAMite SERIES.

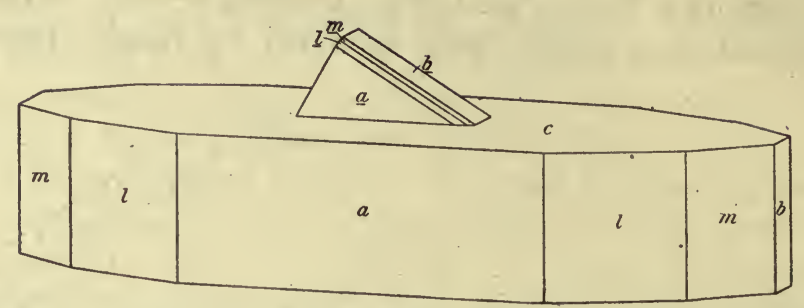

FIGURE 17.-Penetration twin on (02̄3). Forms: $c\{001\}, b\{010\}, a\{100\}, m\{110\}, l\{210\}$.

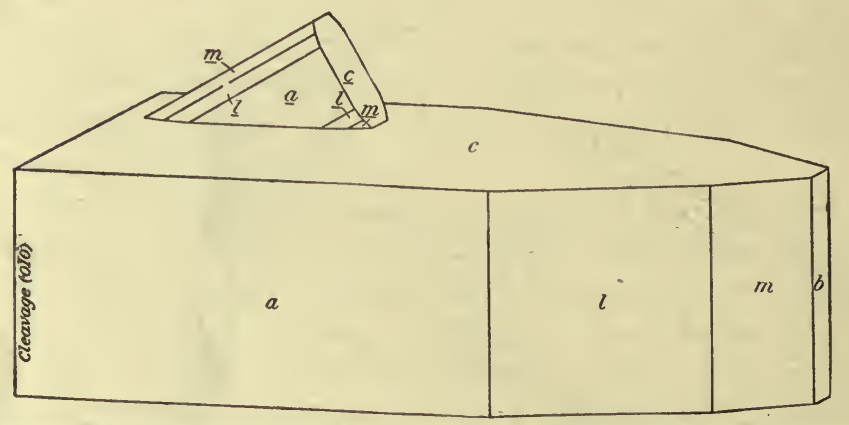

FIGURE 18. -Penetration twin on (023). Forms: $c\{001\}, b\{010\}, a\{100\}, m\{110\}, l\{210\}$.

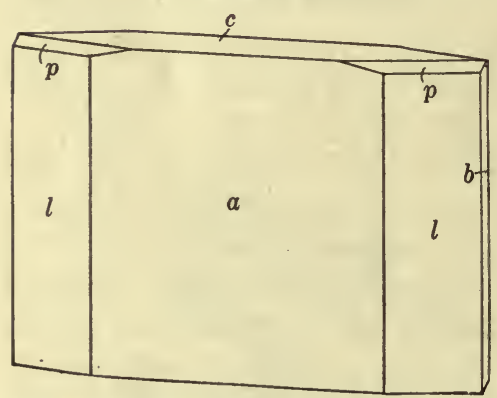

FIGURE 19. -Crystal 29, showing rare form $p$. Forms: $c\{001\}, b\{010\}, a\{100\}, l\{210\}, p\{214\}$.

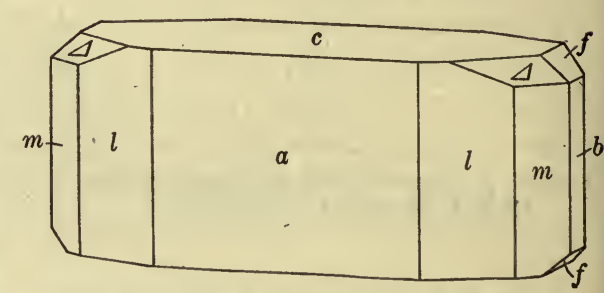

Figure 20.-Crystal 32. Forms: $c\{001\}, b\{010\}$, $a\{100\}, m\{110\}, l\{210\}, f\{011\}, \Delta\{112\}$.

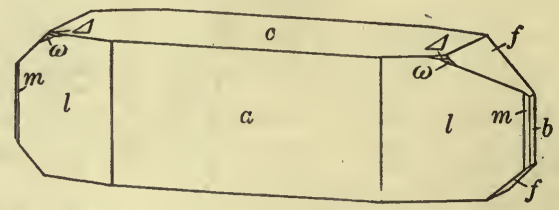

FIGURE 21. -Crystal 33. Wedge-shaped crystal with unequal development of the faces of $f$. Forms: $c\{001\}, b\{010\}, a\{100\}, m\{110\}, l\{210\}, f\{011\}, \Delta\{112\}, \omega\{111\}$. 


\section{DESCRIPTION OF MEASURED CRYSTALS.}

Only such crystals as are illustrated by drawings will be here mentioned. The general types of habit have already been shown under the section entitled "Habit," where drawings of a few of the measured crystals were also introduced. In general the following figures show the crystals in their ideal development. As most of them were bounded on one side by the cleavage face (0I0) the exact dimension of the crystals in this direction could only bo estimated, but by observing similar crystals that were intact it is believed that the proportions shown in the figures closely approximate the true relative dimensions. The crystals illustrated will bo grouped under the five habits.

Crystal 29 (fig. 19) is simple in its combination but shows the rare form $p\{214\}$ fairly well developed. It is, moreover, except $c\{001\}$, the only terminal form on this crystal. Crystal No. 32 (fig. 20) shows a common combination for a number of minute stout crystals in which the wedge shape is not so characteristic as in crystal No. 33 (fig. 21). Here also the upper and lower faces of $f\{011\}$ are unequally developed. With the large development of $l\{210\}$ the pyramid faces generally become smaller.

Crystal 5 (fig. 22) is remarkable in possessing such a small orthopinacoid, $a\{100\}$, the large faces of $n\{810\}$ seeming to replace the usually large faces of $a$. Crystals 6 (fig. 23) and 9 (fig. 24) are both shown in their actual condition, with one side bounded by the cleavage face (010). Both of them show a line face of the rare negative dome $r\{\overline{1} .0 .11\}$ and figure 24 also shows the large positive dome $t\{102\}$. The rare prism $d\{310\}$ is shown as a line face, and a face of $j\{610\}$, though not shown, is also present. Crystal 13 (fig. 25) shows a number of new and rare forms, all as narrow faccs, generally mere line faces, except one form which is present as a minute equidimensional face. The new forms $H\{904\}, A\{337\}$, $B\{123\}$, and the rare forms $n\{810\}$ and $u\{104\}$ are the ones referred to. The clinodome, $f\{011\}$, is much narrower and longer than is usual for the faces of this form. Crystal 16 (fig. 26) gives a combination seen on numerous crystals not measured. The new form $H\{904\}$ is genierally present on such crystals. Crystal 17 (fig. 27) shows $j\{610\}, n\{810\}$, and $o\{111\}$ besides the more common forms. Crystal 18 (fig. 28) shows the striations observed on $\Delta\{112\}$, these striæ being parallel to the intersection edges (112):(001) and (112) : (210), respectively. The crystal is also more elongated in a vertical direction than is usual. Crystal 19 (fig. 29) shows a number of new pyramids, namely, $D\{313\}, B\{123\}, E\{5.9 .14\}$, and the rare pyramid $p\{214\}$. The zonal relationships of $\Delta(112)$, $E(5.9 .14), B(123), f(011)$, and $m^{\prime}(\overline{1} 10)$ could be well seen on this crystal. Crystal 20 (fig. 30) also shows the new form $E\{5.9 .14\}$, as well as $A\{337\}$ and $H\{904\}$.

$35659^{\circ}-$ Bull. $583-14-5$ 


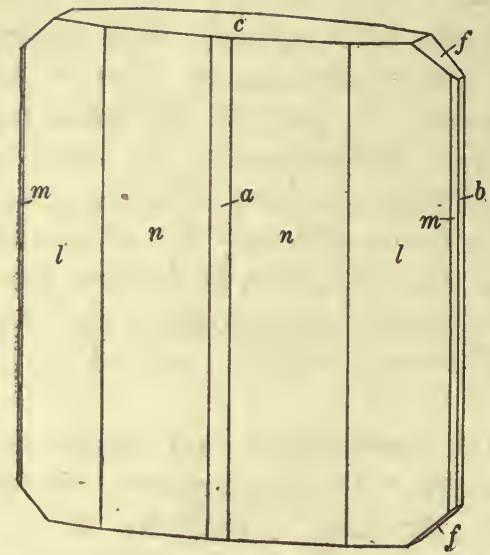

Figure 22,-Crystal 5, remarkable for its small orthopinacoid $a\{100\}$. Forms: $c\{100\}, b\{010\}$, $a\{100\}, m\{110\}, l\{210\}, n\{810\}, f\{011\}$.

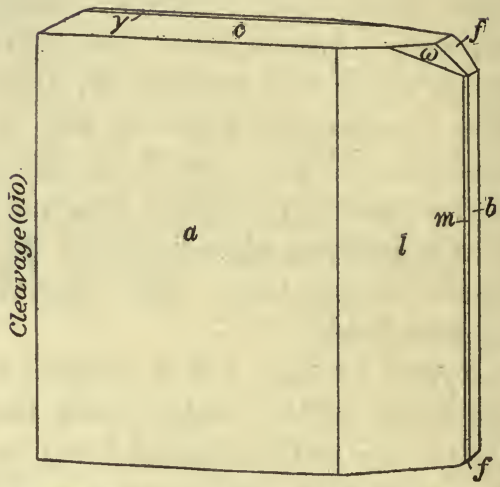

FIGURE 23.-Crystal 6, with rare form $r$. Forms: $c\{001\}, b\{010\}, a\{100\}, m\{110\}, l\{210\}, f\{011\}$, $r\{1.0 .11\}, \omega\{111\}$.

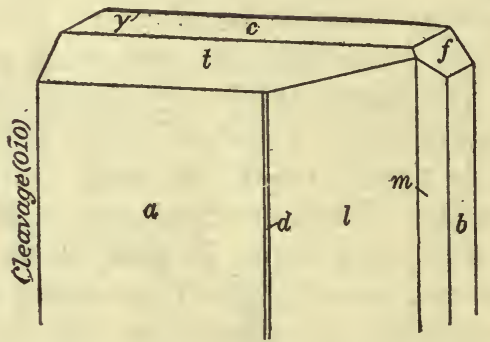

FigORE 24.-Crystal 9, with rare forms $r$ and $d$. Forms: $c\{001\}, b\{010\}, a\{100\}, m\{110\}, l\{210\}, d\{310\}$, $f\{011\}, t\{102\}, r\{1.0 .11\}$. The form $j\{610\}$, not shown in the figure, is also present on this crystal.

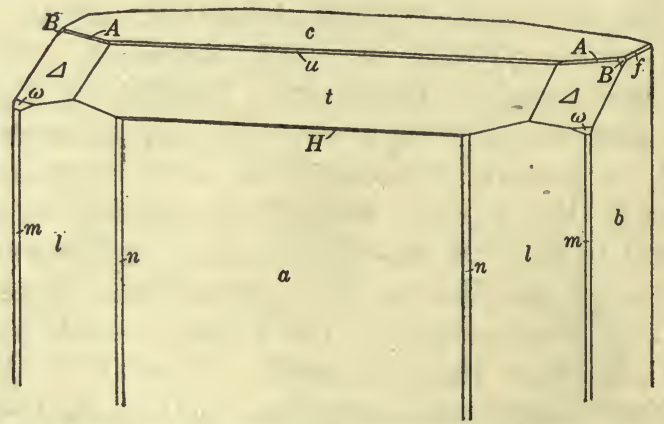

FrguRE 25.-Crystal 13, showing the new forms $A, B$, and $I$ and the rare forms $n$ and $u$. Forms: $c\{001\}$, $b\{010\}, a\{100\}, m\{110\}, l\{210\}, n\{810\}, f\{011\}, u\{104\}, t\{102\}, H\{904\}, A\{337\}, \Delta\{112\}, \omega\{111\}, B\{123\}$. 
Crystal 36 (fig. 31 ) shows a cubic crystal somewhat elongated in the vertical direction. The form $t\{102\}$ is invariably present on these crystals, as is also generally $\Delta\{112\}$. Figure 32 illustrates a
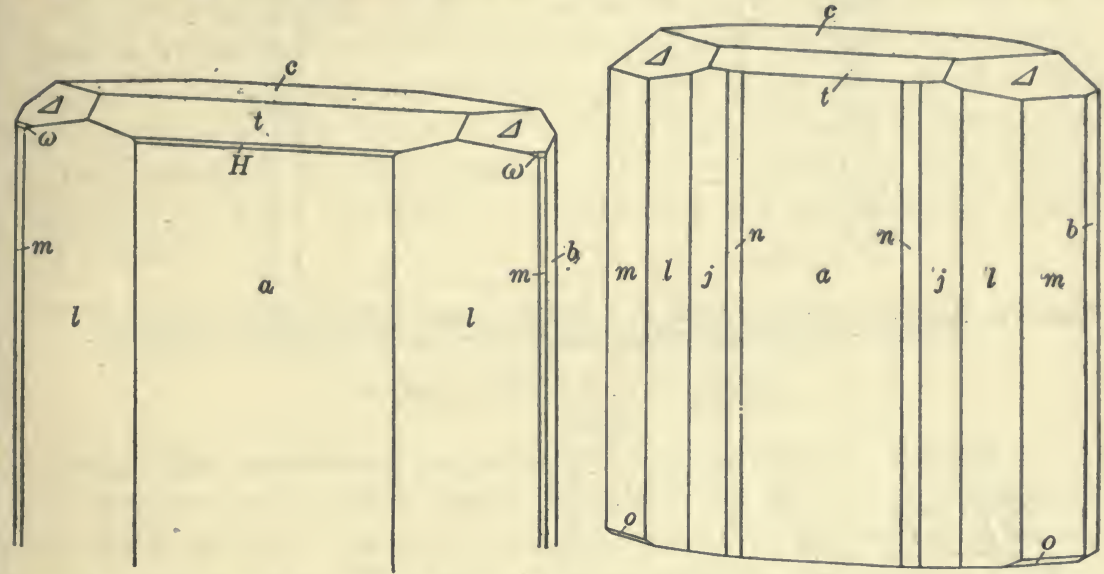

Figure 26.-Crystal 16, a combination observed on Figure 27.-Crystal 17, showing rare forms many erystals not measured. Forms: $c\{001\}, b\{010\}, \quad n, j$, and o. Forms: $c\{001\}, b\{010\}, a\{100\}$, $a\{100\}, m\{110\}, l\{210\}, t\{102\}, H\{904\}, \Delta\{112\}, \omega\{111\}$. $m\{110\}, l\{210\}, j\{610\}, n\{810\}, t\{102\}, \Delta\{112\}$, oII11\}.

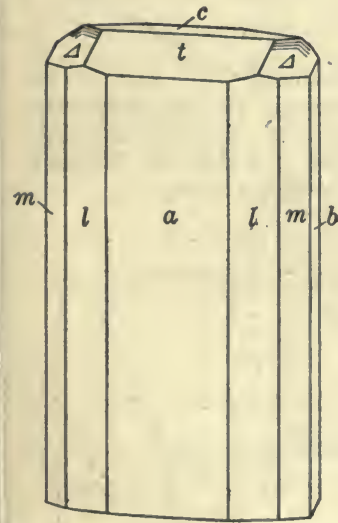

FIGURE 28.-Crystal 18, showing striations on $\triangle$. Forms: $c\{001\}, b\{010\}, a\{100\}, m\{110\}$, $l\{210\}, t\{102\}, \Delta\{112\}$.

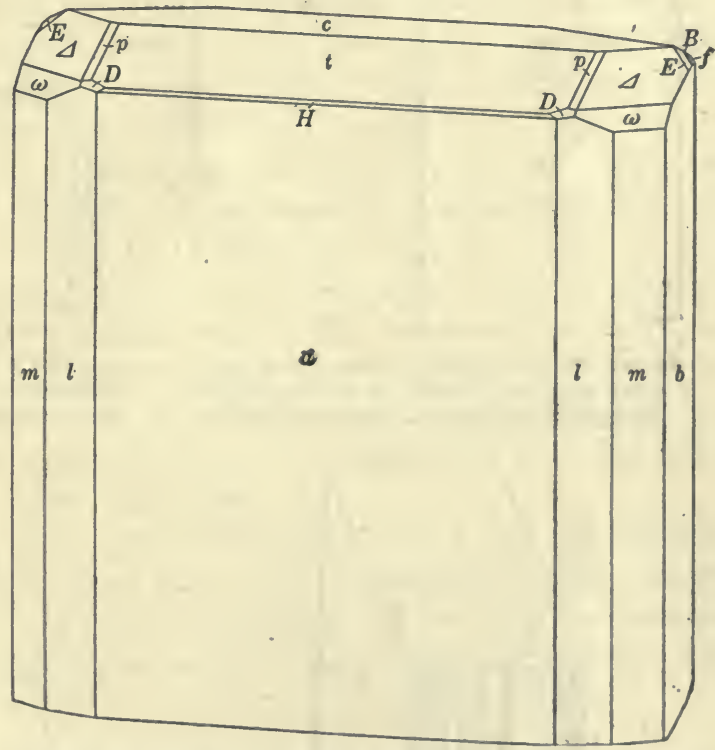

Figure 29.-Crystal 19, showing new forms $D, B$, and $E$. The zone $\Delta\{112\}, E\{5.9 .14\}, B\{12\}\}, f\{011\}$, and $m^{\prime}\{110\}$ is well shown. Other forms are $c\{001\}, b\{010\}, a\{100\}, m\{110\}, l\{210\}$, $t\{102\}, H\{904\}, \omega\{111\}, p\{214\}, D\{313\}$.

cubic crystal apparently slightly elongated in the direction of the $a$ axis, but in reality the original crystal was elongated parallel to the $b$ axis, as the crystal shown in the drawing is incomplete, part of 


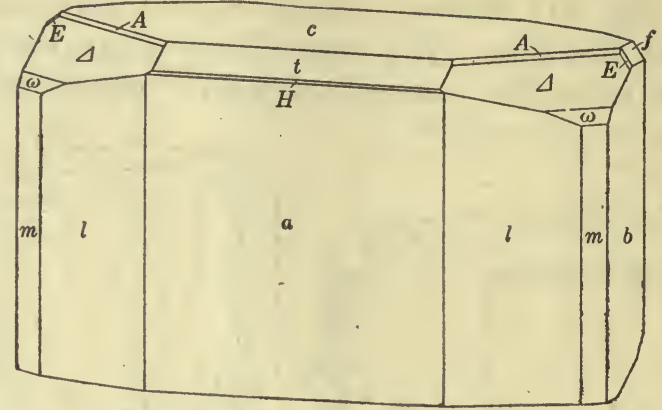

Figure 30.-Crystal 20, with new forms $H, A$, and $E$. Forms: $c\{001\}, b\{010\}, a\{100\}, m\{110\}, l\{210\}$, $f\{011\}, t\{102\}, H\{904\}, A\{337\}, \Delta\{112\}, \omega\{111\}, E\{5.9 .14\}$.

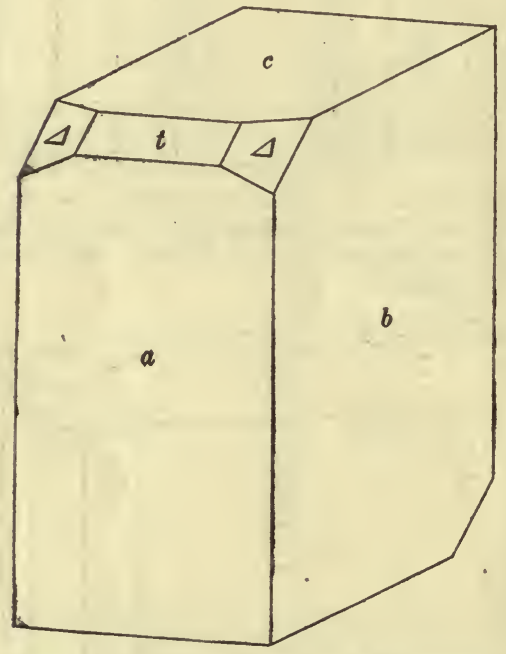

BIGURE 31.-Crystal 36, a cubic crystal, somewhat elongated parallel to its vertical axis. Forms: $c\{001\}, b\{010\}, a\{100\}, t\{102\}, \Delta\{112\}$.

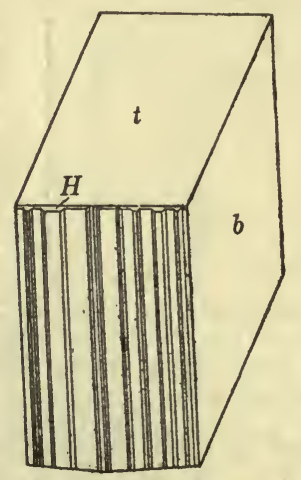

Fraure 33.-Rhombic crystal (No. 25), with the broad orthopinacoid replaced by numerous narrow alternating faces of $a\{100\}$ and $l\{210\}$.

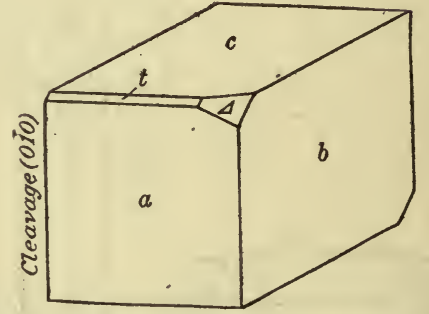

Figure 32.-Cubic crystal (No.37), apparently elongated parallel to $a$ axis, but in reality elongated parallel to $b$ axis, the left-hand side of the crystal having cleaved off.

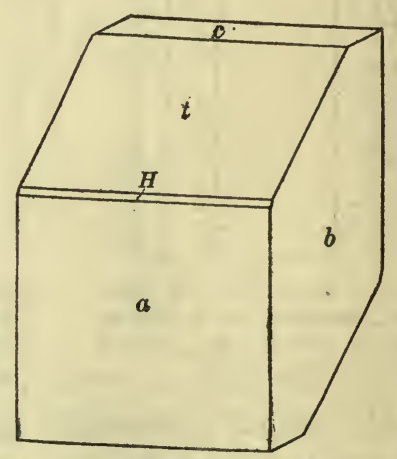

Frgure 34.-Crystal 26, a rhombic crystal. Forms: $c\{001\}, b\{010\}, a\{100\}, t\{102\}, H\{904\}$. 
it having cleaved off. The face of $t\{102\}$ is much narrower than that on figure 31.

Crystal 25 (fig. 33) shows a rhombic crystal similar to those shown in figures 7 and 13 (pp. 57, 59), with the broad orthopinacoid $a\{100\}$, replaced by numerous narrow alternating faces of $a\{100\}$ and $l\{210\}$, those of $l\{210\}$ being much narrower than those of $a\{100\}$. The form $H\{904\}$ is also present. The drawing is, however, but a poor representation of the true appearance of the crystal. Crystal No. 26 (fig. 34) shows the rhombic combination, $a, b, t$, modified by $c\{001\}$ and $H\{904\}$.

\section{FORM SYSTEM OF THE WOLFRAMTTE GROUP.}

\section{CRITICAL STUDY OF FORMS.}

Before the monoclinic character of wolframite was determined it was considered as orthorhombic, and it is therefore not possible to tell which are the negative and which are the positive forms in the earlier descriptions. The list of forms is fairly extensive, a total of 49 being recorded. Some of these forms will be briefly commented on, as follows:

$S\{7.11 .0\}$ was described by Warren as new and the letter $i$ assigned to it. As, however, $i$ had already been preempted by the form $\{\overline{4} 03\}$, the letter $S$ is assigned to the form $\{7.11 .0\}$. The measured angle is given as follows: $(7.11 .0):(7.11 .0)=74^{\circ} 51^{\prime}$. The calculated value is $75^{\circ} 16^{\prime}$ and the calculated value for the simpler form $\{580\}$ is $74^{\circ} 16^{\prime}$. The differences between the angles measured and the values calculated are, for $\{7.11 .0\} 0^{\circ} 25^{\prime}$ and for $\{580\} 0^{\circ} 35^{\prime}$. Although the difference is slightly less for the more complex symbol, the agreement is far from satisfactory. The correct symbol of the form is therefore in doubt, and, though the indices would seem to be possibly simpler than $\{7.11 .0\}$, these indices are inserted in the table of forms, but are marked with a (?) to indicate that the symbols need verification. (See also p. 55.)

$w\{021\}$ was noted only by Descloizeaux and by Jeremejew. Attention is called to the fact that $\{021\}$ occupies almost exactly the same position as $c\{001\}$ in twin position. It is therefore possible that a face of $c\{001\}$ in twin position (as shown in fig. 35) was measured and taken for (021).

$$
\begin{aligned}
& c(001): w(021)=60^{\circ} 01^{\prime} \text { (calculated). } \\
& c(001): \varepsilon(001)=60^{\circ} 02^{\prime} \text { (calculated; p. } 62
\end{aligned}
$$

The difference between the two values is so small as to be unmeasurable. It seems right, therefore, to regard the form $w\{021\}$ as doubtful and as at least needing verification before it can be accepted as a definite form. 
$g\{095\}$, found only by Descloizeaux, also needs verification. The measured angle agrees much better with the slightly more complex form $\{0.11 .6\}$.

(011) : (095) $=16^{\circ} 47^{\prime}$ (measured by Descloizeaux).

(011) : (095) $=16^{\circ} 26^{\prime}$ (calculated); difference $=+21^{\prime}$.

(011) : $(0.11 .6)=16^{\circ} 54^{\prime}$ (calculated); difference $=-07^{\prime}$.

The form is therefore considered doubtful, on account of the uncertainty of its symbol and because it needs verification.

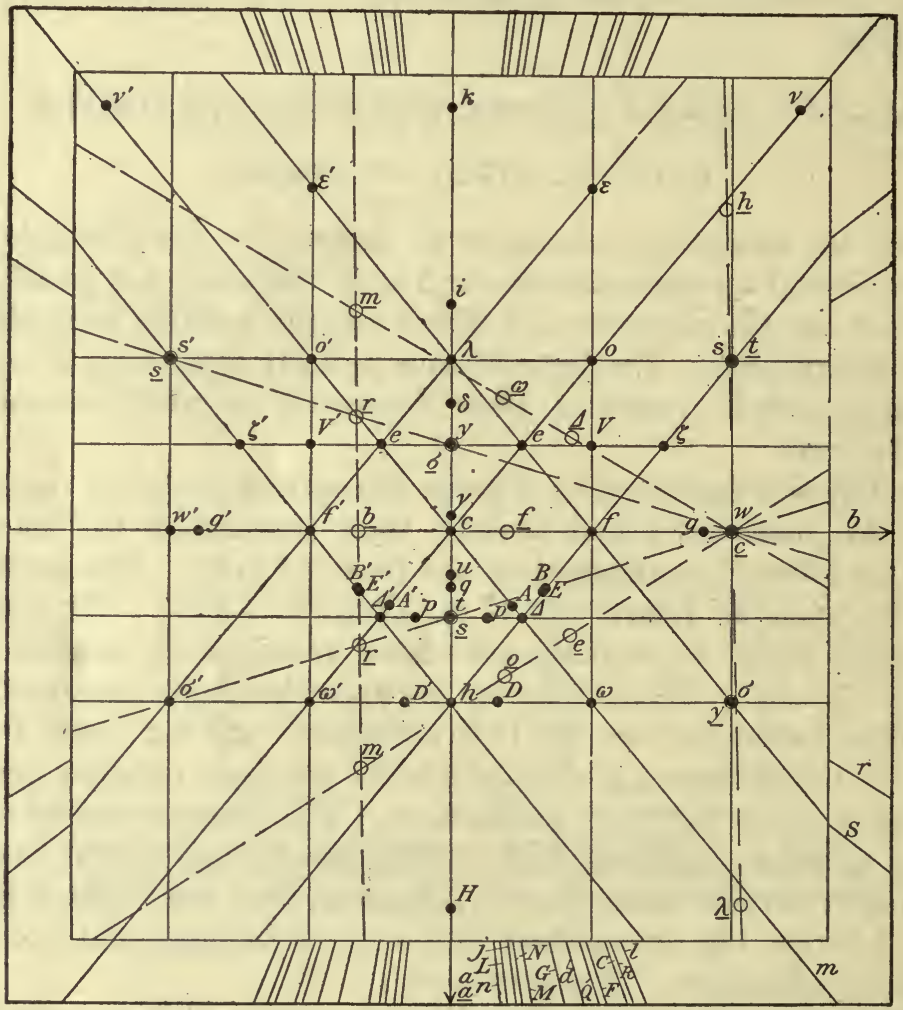

FiaURE 35.-Gnomonic projection of forms of the wolframite group. Several forms are plotted in twin position (open circle) to show their close position to untwinned forms. Thus note particularly $\underline{\mathrm{s}}$ and $w$, $\varepsilon$ and $t, \underline{y}$ and $\sigma, \underline{t}$ and $s, \underline{s}$ and $s, \underline{A}$ and $V$.

$\delta\{\overline{3} 04\}$, described only by Groth and Arzruni, is also doubtful, as the measured angles vary considerably from the values calculated for them.

Angles for the form $\delta\{\overline{3} 04\}$.

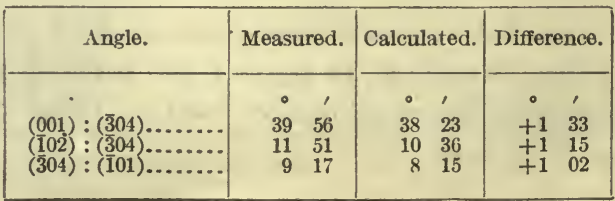


$\lambda\{\overline{1} 01\}$, described first by Groth and Arzruni and later noted by Groth (but without measurement), is also doubtful. (001) : (101) = $48^{\circ} 37^{\prime}$ measured and $46^{\circ} 38^{\prime}$ calculated, the dufference being $1^{\circ} 59^{\prime}$. $z\{113\}$ given by Miller ${ }^{1}$ has always been considered a questionable form. Though inserted by Goldschmidt in his Winkeltabellen with a query, it had best be omitted. The symbol may be a misprint for $\{112\}$.

Eakle gives the letter $v$ to a new form $\{\overline{1} 22\}$ on wolframite from Nevada, but as the letter $v$ is already preempted by the form $\{\overline{5} 52\}$, Eakle's letter is changed to $V$. Eakle's letter $h$ should be changed to $d$ and $d$ changed to $\varepsilon$.

It may be noted, too, that the correctness of the positive or negative character of several of the forms listed is very questionable. This is particularly true of the domes described by Krenner, who himself called attention to this uncertainty.

Figure 35 shows the gnomonic projection of all the known forms of the wolframite series except $\tau\{321\}$, which falls outside of the projection, and $x\{754\}$, which was described after the gnomonic projection was drawn and reproduced. The position of the forms is indicated in figure 35 by dots, whereas the position of some of the forms in twin position (twinned on $\{023\}$ ) is shown by open circles.

All the forms lie in well-developed zones. The prism zone is the richest, containing a total of 17 forms, but hardly any of the simple zones are poor in forms.

The position of many of the twinned forms is nearly identical with other forms which are not twinned and which are in their normal position, as, for example, $\underline{y}\{\overline{1} 02\}$ and $\sigma\{121\}, \underline{c}\{001\}$ and $w\{021\}$, $\underline{t}\{102\}$ and $s\{\overline{1} 21\}, \underline{s}\{\overline{1} 21\}$ and $t\{102\}, \underline{\sigma}\{121\}$ and $y\{\overline{1} 02\}, \underline{s}\{\overline{1} 21\}$ and $s\{\overline{1} 21\}$.

\section{FORMS AND COORDINATE ANGLES.}

The following table of forms and coordinate angles shows several points to which attention may be called. If a form is considered doubtful-that is, if it seems uncertain whether such a form actually exists - the question mark used to indicate this is placed with and immediately following the letter of the form. Thus $w$ ? \{021\} means that there is doubt as to whether such a form has actually been found. If, on the other hand, there is no question about the existence of the form, but the symbols seem to be incorrectly determined, or at least a verification of the correctness of the measurement is desired, the question mark is placed after the symbols, thus $S\{7.11 .0\}$ ?.

References are given when the form has been seen and described by only one observer or two independent observers. If at least three different observers have noted the form its confirmation would seem 
to be so well established that references to it are in general not necessary. The occurrence of the form on the three members of the wolframite group has also been noted.

Forms and coordinate angles, wolframite group.

$\left[a=0.8255 ; c=0.8664 ; \beta=89^{\circ} 32^{\prime}.\right]$

\begin{tabular}{|c|c|c|c|c|c|c|c|c|c|}
\hline \multirow{2}{*}{ No. } & \multirow{2}{*}{$\begin{array}{c}\text { Letter. } \\
.\end{array}$} & \multicolumn{2}{|c|}{ Symbol. } & \multirow{2}{*}{$\phi$} & \multirow{2}{*}{$\rho$. } & \multirow{2}{*}{$\begin{array}{l}\text { Refer- } \\
\text { ences. } a\end{array}$} & \multirow{2}{*}{$\begin{array}{c}\text { Ferberite, } \\
\text { FeWOA. }\end{array}$} & \multirow{2}{*}{$\begin{array}{c}\text { Wolframite, } \\
\text { (Fe, Mn) } \\
\text { WO }\end{array}$} & \multirow{2}{*}{$\begin{array}{l}\text { Hübnerite, } \\
\text { MnWO }\end{array}$} \\
\hline & & $\begin{array}{c}\text { Gold- } \\
\text { schmidt. }\end{array}$ & Miller. & & & & & & \\
\hline $\begin{array}{l}1 \\
2 \\
3 \\
4 \\
5\end{array}$ & $\begin{array}{l}c \\
b \\
a \\
r \\
S\end{array}$ & $\begin{array}{c}0 \\
0 \infty \\
\infty 0 \\
\infty 22 \\
\infty 1 y_{7}^{3}\end{array}$ & $\begin{array}{r}001 \\
010 \\
100 \\
120 \\
7.11 .0 ?\end{array}$ & $\begin{array}{rl}\circ & 1 \\
90 & 00 \\
0 & 00 \\
90 & 00 \\
31 & 12 \\
37 & 38\end{array}$ & $\begin{array}{cc}0 & , \\
0 & 28 \\
90 & 00 \\
90 & 00 \\
90 & 00 \\
90 & 00\end{array}$ & . & $\begin{array}{l}c \\
b \\
a \\
\tau \\
S\end{array}$ & $\begin{array}{c}c \\
\\
b \\
a \\
r \\
r \\
\ldots .\end{array}$ & $\begin{array}{c}c \\
b \\
a \\
a . .\end{array}$ \\
\hline $\begin{array}{r}6 \\
7 \\
8 \\
9 \\
10\end{array}$ & $\begin{array}{l}m \\
l \\
R \\
C \\
F\end{array}$ & $\begin{array}{c}\infty \\
2 \infty \\
2, \infty \\
7, \infty \\
\frac{5}{2} \infty \\
\frac{5}{2} \infty\end{array}$ & $\begin{array}{r}110 \\
210 \\
15.7 .0 \\
940 \\
520\end{array}$ & $\begin{array}{ll}50 & 27 \\
67 & 34 \\
68 & 58 \\
69 & 51 \\
71 & 44\end{array}$ & $\begin{array}{ll}90 & 00 \\
90 & 00 \\
90 & 00 \\
90 & 00 \\
90 & 00\end{array}$ & & $\begin{array}{c}m \\
l \\
R \\
C \\
F\end{array}$ & 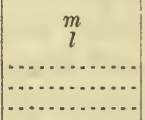 & $\begin{array}{l}m \\
l \\
\cdots \\
\cdots \\
\cdots\end{array}$ \\
\hline $\begin{array}{l}11 \\
12 \\
13 \\
14 \\
15\end{array}$ & $\begin{array}{l}Q \\
d \\
G \\
M \\
N\end{array}$ & $\begin{array}{l}\frac{8}{3} \infty \\
3 \infty \\
\frac{7}{2} \infty \\
5 \infty \\
\frac{13}{2} \infty\end{array}$ & $\begin{array}{r}830 \\
310 \\
720 \\
510 \\
11.2 .0\end{array}$ & $\begin{array}{ll}72 & 48 \\
74 & 37 \\
76 & 44 \\
80 & 38 \\
81 & 28\end{array}$ & $\begin{array}{ll}90 & 00 \\
90 & 00 \\
90 & 00 \\
90 & 00 \\
90 & 00\end{array}$ & & $\begin{array}{l}q \\
G \\
G \\
M \\
N\end{array}$ & $\begin{array}{l}\cdots \\
\cdots \\
\cdots\end{array}$ & $\begin{array}{l}Q \\
d \\
\cdots\end{array}$ \\
\hline $\begin{array}{l}16 \\
17 \\
18 \\
19 \\
20\end{array}$ & $\begin{array}{l}j \\
L \\
n \\
w q \\
g q\end{array}$ & $\begin{array}{l}6 \infty 0 \\
700 \\
800 \\
02 \\
0 \% .\end{array}$ & $\begin{array}{l}610 \\
710 \\
810 \\
021 \\
095\end{array}$ & $\begin{array}{rl}82 & 10 \\
83 & 16 \\
84 & 06 \\
0 & 16 \\
0 & 18\end{array}$ & $\begin{array}{ll}90 & 00 \\
90 & 00 \\
90 & 00 \\
60 & 00 \\
57 & 20\end{array}$ & $\begin{array}{r}12 \\
13 \\
4,13 \\
2,3 \\
2\end{array}$ & $\begin{array}{l}i \\
L \\
n \\
\cdots\end{array}$ & $\begin{array}{l}n \\
w \\
g\end{array}$ & \\
\hline $\begin{array}{l}21 \\
22 \\
23 \\
24 \\
25\end{array}$ & $\begin{array}{l}f \\
\gamma \\
u \\
q \\
y\end{array}$ & $\begin{array}{c}01 \\
-120 \\
+\frac{1}{1} 0 \\
+\frac{1}{3} 0 \\
+\frac{1}{3} 0 \\
-\frac{1}{2} 0\end{array}$ & $\begin{array}{r}011 \\
1.0 .11 \\
104 \\
103 \\
102\end{array}$ & $\begin{array}{rr}0 & 32 \\
90 & 00 \\
90 & 00 \\
90 & 00 \\
90 & 00\end{array}$ & $\begin{array}{rr}40 & 54 \\
4 & 59 \\
15 & 08 \\
19 & 41 \\
27 & 19\end{array}$ & $\begin{array}{r}4,13 \\
3,13 \\
3\end{array}$ & $\begin{array}{l}f \\
r \\
u \\
y\end{array}$ & $\begin{array}{l}f \\
\gamma \\
u \\
q \\
y\end{array}$ & a... \\
\hline $\begin{array}{l}26 \\
27 \\
28 \\
29 \\
30\end{array}$ & $\begin{array}{c}-t \\
8 q \\
\lambda q \\
h \\
i\end{array}$ & $\begin{array}{l}+\frac{1}{2} 0 \\
-\frac{3}{4} 0 \\
-10 \\
+10 \\
-10 \\
-\frac{4}{8} 0\end{array}$ & $\begin{array}{l}102 \\
304 \\
101 \\
101 \\
\overline{4} 03\end{array}$ & $\begin{array}{ll}90 & 00 \\
90 & 00 \\
90 & 00 \\
90 & 00 \\
90 & 00\end{array}$ & $\begin{array}{ll}28 & 03 \\
37 & 55 \\
46 & 10 \\
46 & 36 \\
54 & 17\end{array}$ & $\begin{array}{r}4 \\
4,6 \\
5,6 \\
5\end{array}$ & 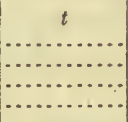 & $\begin{array}{l}t \\
d \\
\lambda \\
h \\
i\end{array}$ & $\begin{array}{l}t \\
t \\
\cdots\end{array}$ \\
\hline $\begin{array}{l}31 \\
32 \\
33 \\
34 \\
35\end{array}$ & $\begin{array}{l}H \\
k \\
\zeta \\
V \\
s\end{array}$ & $\begin{array}{l}+\frac{1}{4} \\
-\frac{6}{3} 0 \\
-\frac{3}{2} \\
-\frac{3}{2} \\
-12 \\
-12\end{array}$ & $\begin{array}{l}904 \\
502 \\
132 \\
122 \\
121\end{array}$ & $\begin{array}{ll}90 & 00 \\
90 & 00 \\
21 & 41 \\
30 & 48 \\
31 & 00\end{array}$ & $\begin{array}{ll}67 & 07 \\
69 & 04 \\
54 & 26 \\
45 & 15 \\
63 & 41\end{array}$ & $\begin{array}{r}13 \\
5 \\
5 \\
18 \\
18 \\
\ldots .6 \%\end{array}$ & 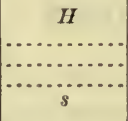 & $\begin{array}{l}k \\
\zeta \\
s\end{array}$ & \\
\hline $\begin{array}{l}36 \\
37 \\
38 \\
39 \\
40\end{array}$ & $\begin{array}{l}\stackrel{\sigma}{B} \\
\stackrel{E}{D} \\
e \\
e\end{array}$ & $\begin{array}{c}+12 \\
+13 \\
+13 \\
+r^{8} \\
+1 \frac{1}{3} \\
-12 \\
-13\end{array}$ & $\begin{array}{r}121 \\
123 \\
5.9 .14 \\
313 \\
112\end{array}$ & $\begin{array}{ll}31 & 24 \\
31 & 47 \\
34 & 31 \\
47 & 21 \\
50 & 01\end{array}$ & $\begin{array}{ll}63 & 46 \\
34 & 12 \\
34 & 03 \\
74 & 44 \\
33 & 59\end{array}$ & $\begin{array}{l}13 \\
13 \\
13\end{array}$ & $\begin{array}{l}B \\
E \\
D \\
e\end{array}$ & 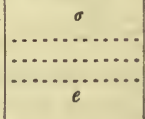 & \\
\hline $\begin{array}{l}41 \\
42 \\
43 \\
44 \\
45\end{array}$ & $\begin{array}{l}o \\
v \\
\omega \\
\Delta \\
A\end{array}$ & $\begin{array}{l}-1 \\
-\frac{5}{2} \\
+1 \\
+\frac{1}{2} \\
+\frac{3}{7}\end{array}$ & $\begin{array}{l}111 \\
\frac{1}{5} 52 \\
111 \\
112 \\
337\end{array}$ & $\begin{array}{ll}50 & 14 \\
50 & 22 \\
50 & 40 \\
50 & 53 \\
50 & 58\end{array}$ & $\begin{array}{ll}53 & 34 \\
73 & 35 \\
53 & 49 \\
34 & 29 \\
30 & 31\end{array}$ & $\begin{array}{r} \\
\cdots \\
\cdots \\
\cdots \\
13\end{array}$ & $\begin{array}{l}0 \\
\omega \\
\Delta \\
A\end{array}$ & 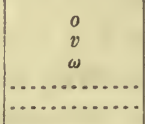 & $\begin{array}{ll}\omega \\
\Delta \\
\Delta\end{array}$ \\
\hline $\begin{array}{l}46 \\
47 \\
48 \\
49\end{array}$ & $\begin{array}{l}x \\
\tau \\
\varepsilon \\
p\end{array}$ & $\begin{array}{l}+\frac{7}{3} 5 \\
+32 \\
-21 \\
+\frac{1}{2} \frac{1}{4}\end{array}$ & $\begin{array}{l}754 \\
321 \\
211 \\
214\end{array}$ & $\begin{array}{ll}59 & 35 \\
61 & 14 \\
67 & 29 \\
67 & 53\end{array}$ & $\begin{array}{ll}64 & 57 \\
74 & 29 \\
66 & 10 \\
29 & 55\end{array}$ & ${ }_{11,13}$ & $p$ & $\cdots$ & $\begin{array}{l}x \\
\tau\end{array}$ \\
\hline
\end{tabular}

a Numbers refer to the Bibliography, pp. 74-75. 


\section{COMBINATIONS OBSERVED ON THE WOLFRAMITE GROUP.}

The following table shows the combinations described on minerals of the wolframite group commencing with the definite sstablishment of the monoclinic character of the group by Descloizeaux in 1850 . As wolframito was considered to be orthorhombic in the earlier descriptions, the combinations of those writers are not given, a's the positive and negative forms can not be differentiated. Numbers after names of authors refer to similar numbers in the bibliography.

Combination No. 10 gives the entire list of forms mentioned by Descloizeaux and doubtless represents several crystals, in part probably the same as combinations Nos. 1, 2, and 3. Combination 11 likewise gives the complete list of forms observed by Jeremejew, as I was not able to decipher the individual combinations from tho Russian text.

Combinations described on crystals of minerals of the wolframite group.

\begin{tabular}{|c|c|c|c|c|c|}
\hline No. & Combination. & Mineral. & Locality. & Author. & Dat \\
\hline 1 & $b a m l f \circ \omega$ & Wolframite & Chanteloube. & Descloizeaux & 1850 \\
\hline 2 & foa & ..... do.. & do. & .....do. (1). & 18 \\
\hline 3 & $a m l f g y t$ & ....do. & 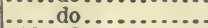 & ......do. (1) & 1850 \\
\hline 4 & $c b a m l f y t$. & 0 & Altenber & do. (1) & 1850 \\
\hline 5 & cam lf sow. & do & ...do... & .do. (1) & 1850 \\
\hline 6 & $a m$ lf $y t s$. & .0 & Zinn & .do. (1) & 1850 \\
\hline 7 & $a m$ if $y t s 0$ & An & ..... do... & ..do. (i) & 1850 \\
\hline 8 & $l f y t$ & $\ldots d d$ & .....do & .....do. (1) & 1850 \\
\hline 9 & bamtos. &..$d c$ & Schlaggen & do. (2) & 1870 \\
\hline 10 & $c b a$ & ... do & & - do. (2) & 1870 \\
\hline 11 & cbarml vofuqyt & ...do. & Russia. & Jeremejew (3). & 1872 \\
\hline 12 & $c b a m n \gamma y \sigma \lambda$ & ...do & Schlaggenwald. & Groth and Arz- & 1873 \\
\hline 13 & bak. & . do & Felsobany & Krer & 1875 \\
\hline 14 & $b a$ & .0 & ...... & $\ldots .$. & 1875 \\
\hline 15 & $b a d l k$. & 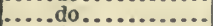 & .d & ....do. (5) & 1875 \\
\hline 16 & $c b d \ldots .$. & $d$ & do... & .....do. (5). & 1875 \\
\hline 17 & bat............ & , & 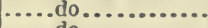 & .....do. $(5)$ & 1875 \\
\hline 18 & bау $h$ h.......... & $\cdots \cdot d$ & . & .....do. (5). & 187 \\
\hline 19 & $\begin{array}{l}b a y, \ldots \ldots . . . . \\
b \text { b }\end{array}$ & $\cdots \cdots$ & $\cdots . .8$ & .....do. (5). & 1875 \\
\hline 20 & $\begin{array}{l}b h v \ldots \ldots \ldots \\
b a i v\end{array}$ & $\cdots \cdot c^{2}$ & $\cdots \cdot c$ & ......do. (5). & 1875 \\
\hline 2 & cbadyik & 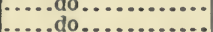 & $\cdots \cdot c$ & .....do. (5). & 187 \\
\hline 23 & cafho...... & $\ldots . d$ & Alter & Groth (6) & 1875 \\
\hline 24 & $a m l \lambda h_{\sigma}$ & 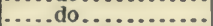 & Zin & Grot & $\begin{array}{l}1878 \\
1878\end{array}$ \\
\hline 25 & ba $m \ldots .$. & ïüìi & $\mathrm{Py}$ & $\ddot{\mathrm{Be}}$ & 1882 \\
\hline 26 & $c b a m l f y 8 \sigma e 0 \omega$ & Wolfr & Sp & Selig! & 1880 \\
\hline 27 & $a m f y$ & & Fí & $r(9)$ & 1888 \\
\hline 28 & $b(a)$ & Hüb & lo.... & Penfield (10). & 1892 \\
\hline 29 & $b(a) \gamma$ & $\cdots \cdots c$ & lexico.... & .....do. (10). & 1892 \\
\hline 30 & $b(a) m Q t \Delta \ldots$ & $\ldots \ldots c$ & $\ldots . d$ & & 189 \\
\hline 31 & a mlft... & Woll & Alt & (11). & 189 \\
\hline 32 & ..... & & $\mathrm{Ja}$ & Jimbo (12)... & 1899 \\
\hline 33 & $c b a S m l f y t \Delta \ldots . . .$. & Ferberite. & Soutl & Warren (13 & 190 \\
\hline 34 & & Wolfr & New South Wales. & An & 1904 \\
\hline 35 & $n$ & Ferbe & Boulder County, & & 1905 \\
\hline 36 & $c b a m$ & 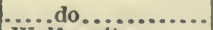 & Greet & B 8 & 1905 \\
\hline 37 & $c$ & Wol & Bol & & 1907 \\
\hline 38 & $c b a$ & 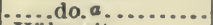 & $\mathrm{Ne}$ & Eakle (18). & 1912 \\
\hline 39 & $c b a m l d t x .$. & Hübnerite.. & Peru. & Tronquoy (19).... & 1913 \\
\hline
\end{tabular}

$a$ Eakle states that "All of the material contains uron and is to be classed as wolframite rather than as hubnerite." His next sentence, "The crystals aro tabular parallel to tho orthopinacoid and some of them aro exceedingly thin and almost transparent, with a deep-red color," would indicate, however, that the material was more likely hübnerite than wolframite. 
The following combinations were observed by the writer on the ferberite from Colorado described in this report:

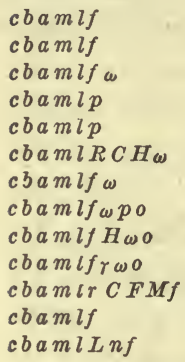

cbamlf
cbaml
cbamlf
cbamlR $Q$ nft
cbat IH
cbatH
cbats
cbat
cbalts
balt $H$
balt $H$
cbat $H$

cbamlf $c b a m l$ cbamlf cbat II E $c b a t H$ $c b a m l f t H_{\omega} \Delta A$ cla mlt $H_{\omega A}$ cbaml Nnft $\Delta O$ $c b a m l R C Q t \Delta$ cba mlft $H B E \omega \Delta p D$ cba m lft $H_{\omega \Delta A}$ cbam lft $E \triangle A$ cbam l Fft $\omega \Delta$

By calculating the percentage occurrence for the 77 combinations listed (the 39 given in the table and the 38 observed by the writer), the forms of the wolframite group fall into three classes, as follows:

(1) Prominent forms:

\begin{tabular}{|c|c|c|c|c|c|c|c|}
\hline $\begin{array}{l}\text { etter...... } \\
\text { ymbol.... }\end{array}$ & $\begin{array}{c}a \\
(100)\end{array}$ & $\begin{array}{c}b \\
(010)\end{array}$ & $\begin{array}{c}m \\
(110)\end{array}$ & $\begin{array}{c}c \\
(001)\end{array}$ & $\begin{array}{c}l \\
(210)\end{array}$ & $\underset{(011)}{f}$ & $\begin{array}{c}t \\
(102)\end{array}$ \\
\hline of occurrenc & 97 & 84 & 75 & 67 & 67 & 57 & 51 \\
\hline
\end{tabular}

(2) Less prominent forms:

Letter.................. $\omega$

Symbol............... (111)

Per cent of occurrence.... 35

$\begin{array}{cccccc}o & \Delta & y & H & s & 0 \\ (\overline{1} 11) & (112) & (\overline{1} 02) & (904) & (\overline{1} 21) & (121) \\ 24 & 21 & 21 & 17 & 12 & 11\end{array}$

(3) Rare forms: All the remaining forms, 35 in number.

\section{BIBLIOGRAPHY.}

1. Descloizeaux, A., Mémoire sur les formes cristallines du wolfram: Annales chim. et phys., 3d ser., vol. 28, p. 163, 1850.

2. Descloizeaux, A., Nouvelles recherches cristallographiques et optiques sur la forme clinorhombique du wolfram: Annales chim. et phys., 4th ser., vol. 19, p. $168,1870$.

3. Jeremejew, P., Wolfram-Krystalle im Vergleich zu den Krystallen des Columbite: Russ.-k. mineral. Gesell. St. Petersburg Verh., 2d ser., vol. 7, p. 301, 1872.

4. Groth, P., and Arzruni, A., Ueber die Krystallform und die optische Eigenschaften des Wolframs und dessen Beziehungen zum Columbit: Poggendorff's Annalen, 5th ser., vol. 29, p. 235, 1873.

5. Krenner, J. A., Wolframit aus dem Trachyte von Felsö-Bánya: Min. pet. Mitt., vol. 5, p. 9, 1875 .

6. Groth, P., Die Mineraliensammlung der Kaiser-Wilhelms-Universität, Strassburg, p. $161,1878$.

7. Bertrand, E., Sur la hübnérite des Pyrénées: Soc. min. de France Bull. 5, p. 90, 1882.

8. Seligmann, G., Mineralogische Notizen, III; 12, Wolframit: Zeitschr. Kryst. Min., vol. 11, p. $347,1886$.

9. Sandberger, F., Ueber Lithionitgranite mit besonderer Rücksicht auf jene des Fichtelgebirges, Erzgebirges und des nördlichen Böhmens: K. bayer. Acad. München, Math.-phys. Classe, Sitzungsber., 1888, p. 423.

10. Penfield, S. L. (with Genth, F. A.), Mineral notes, No. 52: Am. Jour. Sci., 3d ser., vol. 43, p. 184, 1892. 
11. Jeremejew, P., Ueber den Wolframit von der Demidow'schen Kupfergrube in der Näho des Kolywan'schen Bergwerkes, Altai: Russ,-k. mineral. Gesell. Verh., vol. 31, p. 404, 1894.

12. Jimbo, K., Notizen uber die Mineralien von Japan: Tokyo Coll. Sei. Jour., vol. 11, p. $213,1899$.

13. Warren, C. H., Mineralogical notes: Crystal of iron wolframite from South Dakota: Am. Jour. Sci., 4th ser., vol. 11, p. 372, 1901.

14. Anderson, C., Mineralogical notes No. I: Topaz, beryl, vesuvianite, tourmaline, and wolframite: Australian Mus. Records, vol. 5, p. 303, 1904.

15. Moses, A. J., The crystallization of luzonite and other crystallographic studies; Crystallized wolframite from Boulder County, Colo.: Am. Jour. Sci., 4th ser., vol. 20, p. 281, 1905.

16. Böggild, O. B., Mineralogia Groenlandica: Med́delelser om Groenland, No. 32, p. 179, 1905.

17. Spencer, L. J., Minerals from Bolivia: Mineralog. Mag., vol. 14, p. 334, 1905.

18. Eakle, A. S., The minerals of Tonopah, Nev.: California Univ. Dept. Geology Bull., vol. 7, p. 18, 1912.

19. Tronquoy, R., Sur la hübnérite: Soc. franç. minéralogie Bull. 36, p. 113, 1913. 

or $=5$

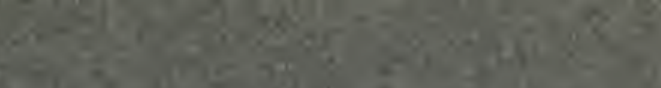

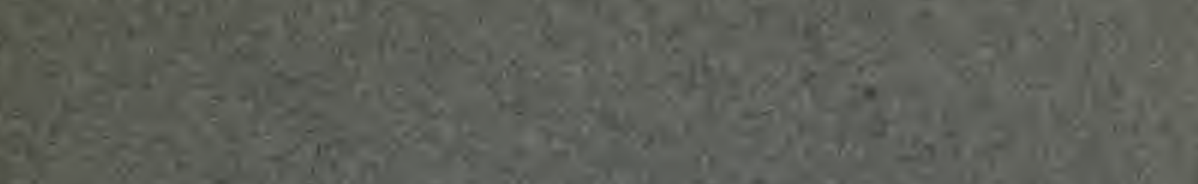

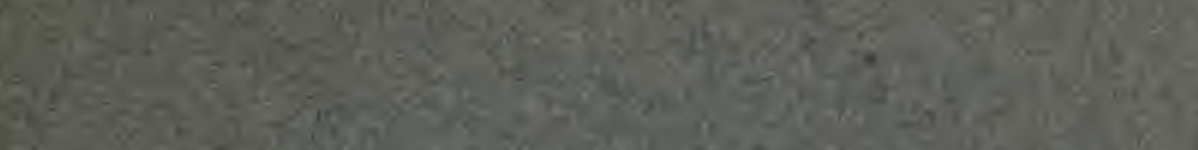

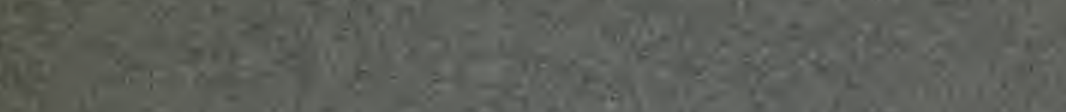

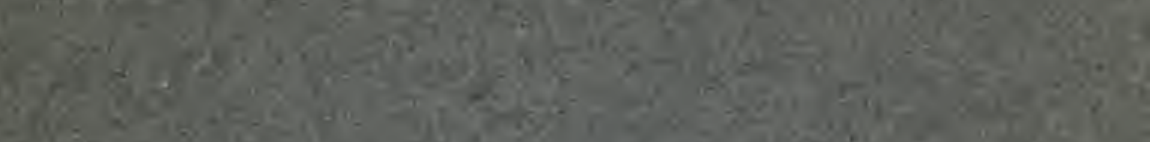

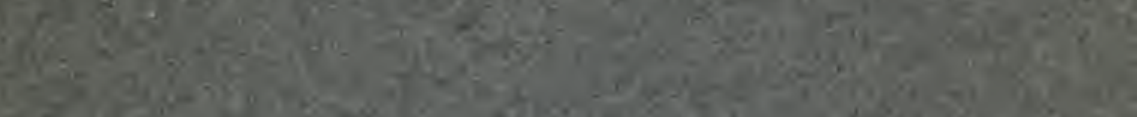

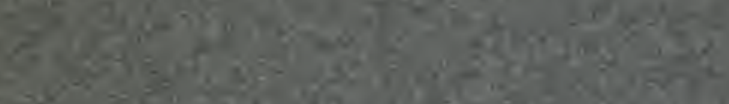

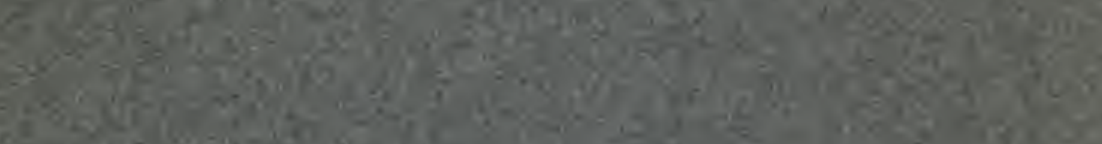

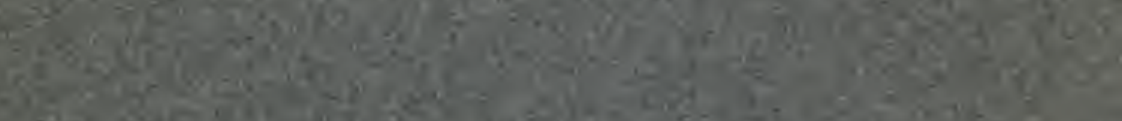

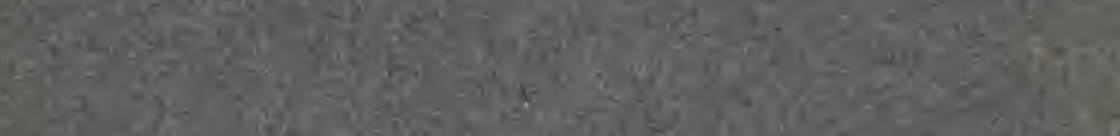

6.

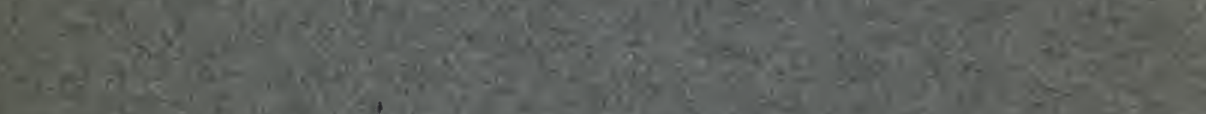

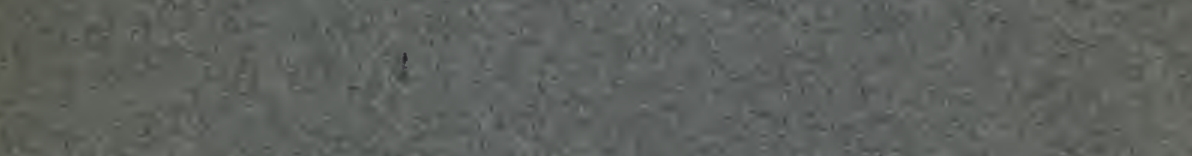

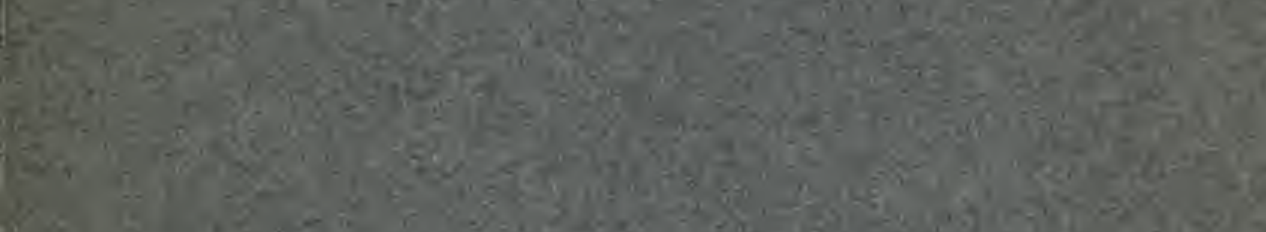

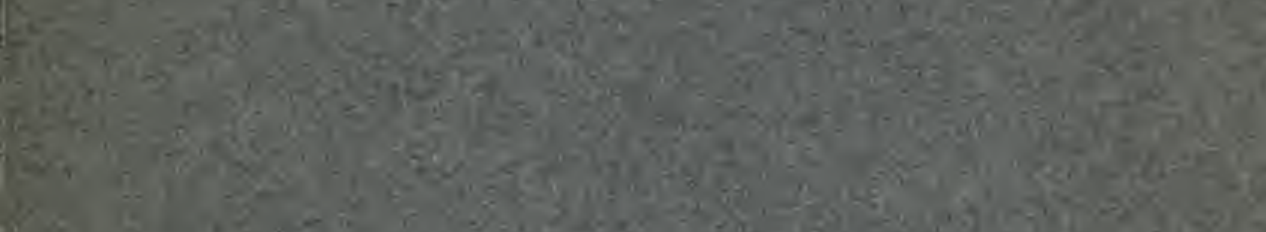

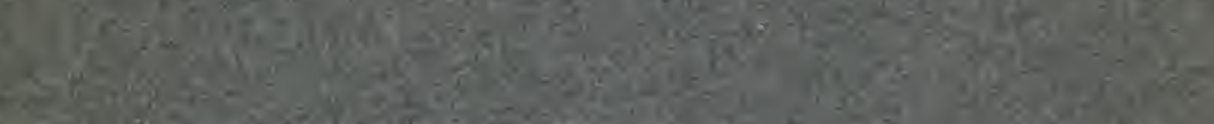

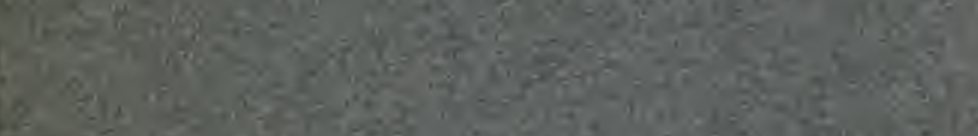

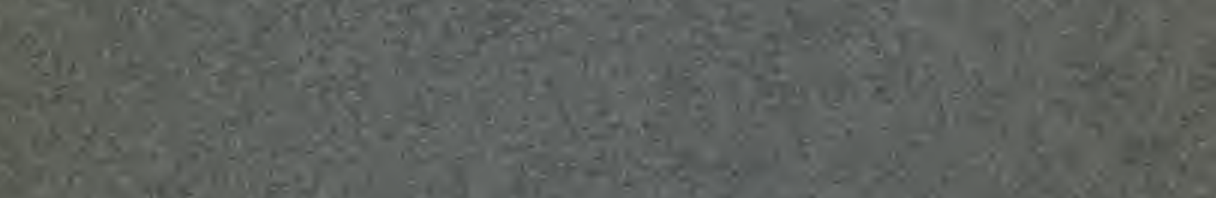

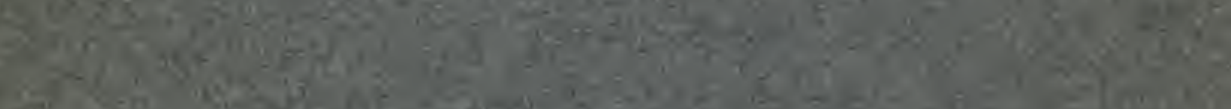

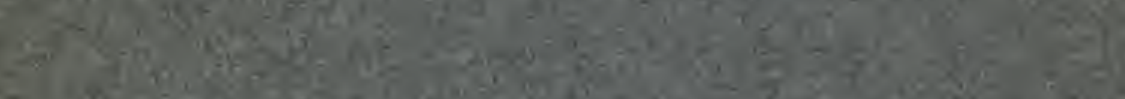

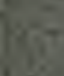

\section{$3 x^{2}+x^{2}=0$}

P.

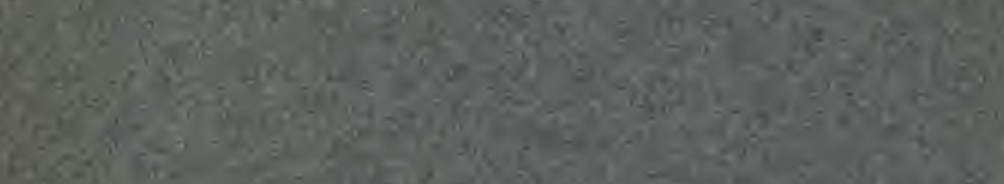

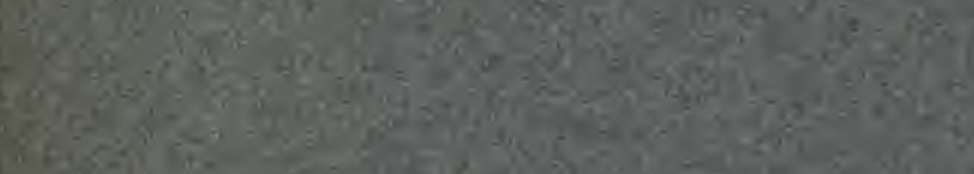

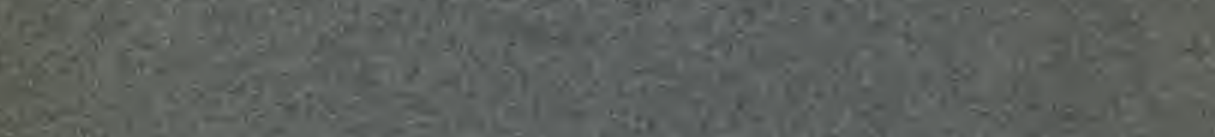

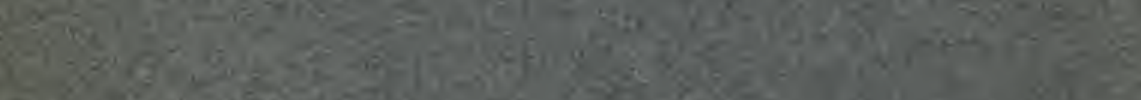

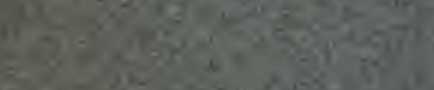






